
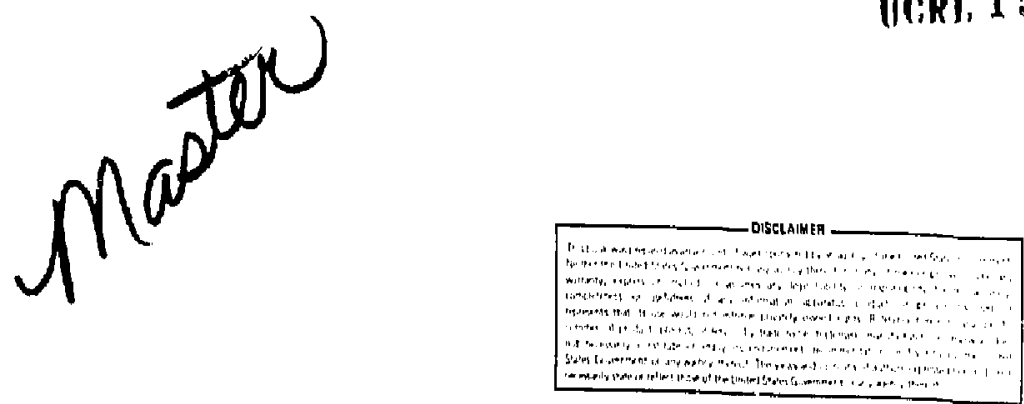

TRANSURANIC CONTAMINATED

WASTE FORM CHARACTERIZATION

AND DATA BASE

VCLUME 1

Sulvi: thed ts

Dr. Henry Cheung

Lowrence Livermore Laboratory

P.O. Box 808, L-390

Livermore, Califarnio 94550

Submitted by:

Dr. W. C. McArthur

B. G. Kniozewycz

July 1980

Revision 1

7. TeRA ADVANCE: SERVICES COFPO AHION

2150 Shottuck Avonus

Berkeley. Californio $0.17 \%$;

475.845 .5200

Berkeley. Colsonto

Dollas, Texis:

Bethesdis Moplan:

Bgion Rouge. Louisigna

Del Mar, Calíforno

New York. New York

Son Antonio, iencs

Denver, Coleresdo

Los Angales, Calfornio 


\section{TABLE OF CONIENTS}

Section Page

PREFACE ...................

1.0 INTRODUCTION. . . . . . . . . . . . . . . $\mid$.

1.I Transuranic (TRU) Contaminated Wastes. . . . . . . . 1-2

1.2 TRU Waste Management Program. . . . . . . . . . . . . 1-6

2.0 BACKGROUND . . . . . . . . . . . . . . . 2-1

2.1 TRU Contaminated Waste Classification . . . . . . . . . 2-1

2.2 Source of TRU Contaminated Woste . . . . . . . . . . 2-3

2.3 TRU Contaminated Waste Containers . . . . . . . . . . 2-13

3.0 COMMERCIAL NUCLE.AR INDUSTRY TRU WASTE

CHARACTERISTICS . . . . . . . . . . . . . 3-1

3.1 Fuel Fabrication Industry . . . . . . . . . . . . . 3-1

3.2 Waste from the Spent Fuel Reprocessing Industry . . . . . . 3-13

3.3 Enrichment Plant Operotions . . . . . . . . . . . 3-41

3.4 Other Potential Sources . . . . . . . . . . . . . . . . 3-42

4.0 DOE TRU WASTE CHARACTERISTICS . . . . . . . . . . 4-I

4.1 Description of TRU Waste Streams . . . . . . . . . . 42

4.2 TRU Waste Forms. . . . . . . . . . . . . . . 4-10

4.3 Transuranic Isotope Content and Contomination Levels. . . . 4 4-17

4.4 TRU Waste Categories. . . . . . . . . . . . . . . 4-28

$4-5$ summary . . . . . . . . . . . . . . 4-29

5.0 POTENTIAL TREATMENT TECHNOLOGY FOR

GENERATED TRU WASTE . . . . . . . . . . . . 5-I

5.1 Sources and Choracteristics of Non-High-Level TRU Waste . . . . 5-3

5.2 Technologies for General Trash . . . . . . . . . . 5-5

5.3 Technologies for Treotment of Discorded Equipment. . . . . . 5-29

5.4 Technologies for Treotment of Wet Wastes . . . . . . . 5-31

5.5 VR Technology Analysis .............. 5-38

5.6 DOE Experience with VR Technology ......... . 5-45 


\section{TABLE OF CONTENTS}

(CONT.)

Section

6.0 IMMOBILIZATION TECHNOLOGIES FOR TRU WASTES, , . . . . . 6-1

6.1 Absorption ..................... 6-2

6.2 Salt Matrix. . . . . . . . . . . . . . 6-2

6.3 Ureo-formaldehyde Resins . . . . . . . . . . . 6-4

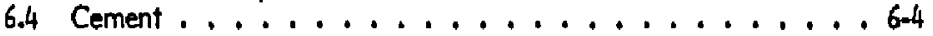

6.5 Blfumen.................... 6-5

6.6 Clay Fixation. .................. 6-. . . .

6.7 Glass .................... 6- . .

6.8 Pelletizotion..................... 6-.

6.9 Modified Vinyl Ester Resins ... . . . . . . . . 6-9

6.10 Compurison of Agents. . . . . . . . . . 6-10

7.0 REFERENCES. ...................... . . . . 


\section{IST OF TABLES}

Iable

I DOE Facilities and Facility Operators Generating TRU Contaminated Waste. . . . . . . . . . . . . . 3

2 Existing DOE Defense-Related Transuranic Wastes . . . . . . . . . II

3 Physical Charocteristics of DOE TRU Wastes . . . . . . . . . 12

4 Rank Ordering of Waste Forms by Volume for Wastes Stored at Idaho from September 1, 1971, to December 21, 1976. . . . . 15

5 Candidote Volume Reduction Technologies . . . . . . . . . . 20

$1-1$ Transuranium Elemenis . . . . . . . . . . . . 1-3

2-1 TRU Isotopic Concentration Limits for Shallow Land Burial . . . . 2-4

2-2 TRU isotopic Concentrations Requiring Disposal by Shallow Lond Burial . . . . . . . . . . . . 2-5

2-3 Cumulative Volume of DOE-Generated TRU-Contaminated Solid Waste Euried and/or Stored ol DOE Sites . . . . . . . . 2-9

2-4 DOE Focilitins and Facility Operators Generoting TRU Contaminated Waste . . . . . . . . . . 2-10

2-5 Cumulative Waste Inventory at Commercial Burial Sites. . . . . . . 2-12

2-6 Results of Waste Container Survey of DOE Waste Generators . . . . 2-16

2-7 DOE Wiaste Container Specificotions . . . . . . . . . 2-18

2-8 TRU Low-Level Waste Packoges in Use . . . . . . . . . 2-19

2-9 Defense Contoct-Handled TRU Woste (Orum) . . . . . . . . 2-21

2-10 Defense Contact-Handled TRU Waste (Box) . . . . . . . . . . 2-22

2-11 Defense Remotely Hondled TRLI Waste . . . . . . . . . . . . . 2-23

3-1 Calculated Yearly Production from 1000 MWe Plant . . . . . . . 3-3

3-2 Existing Mixed-Oxide Fobrication Facilities . . . . . . . . . . 3-4

3-3 Sources and Quantities of Non-High Level MuX Fuel Fabrication TRU-Wastes ................... 3-11 


\section{LIST OF TABLES}

(CONT.)

Table

3-4 Typical Waste Distribution in a MOX Fuel Preparation-

Fobricotion Plant .................... 3-12

3-5 Source of General Trash from Separations Plant . . . . . . . . 3-18

3-6 Combustible Solid Wastes from Reprocessing Operations . . . . . 3-21

3-7 Estimated Volumes of Solid TRU-Viaste . . . . . . . . . . . 3-i4

3-8 Plutonium in solid waste . . . . . . . . . . . . . . 3-25

3-9 Sort of Waste Based Upon Combustibility . . . . . . . . . . . . 3-26

3-10 Distribution of Woste Volume by Container Configuration . . . . . 3-27

3-II Rodiooctive Wastes Generoted Annually at NFS Design Fiate. . . . . . 3-26

3-12 Percentoge Distribution of Plutonium in Solid Waste . . . . . . . 3-30

3-13 Rodiooctivity Levels for TRU Solid Wastes . . . . . . . . . 3-31

3-14 Expected Volumes and Beta-Camma Activity Levels of

Transuranic Wostes from Commercial Fuel Reprocessing Plonts . . . 3-32

3-is Curies of TRU Radio isotopes in the Clodding Woste from

One Metric Ton of Uranium-Enriched Fuel . . . . . . . . . . 3-34

3-16 Curies of TRU Rodioisotopes in the Cladding Waste from

One Netric Ton of Plutonium-Enriched Fuel . . . . . . . 3-35

3-17 Chemical Composition of Zircaloy Alloys . . . . . . . . . 3-36

3-18 Nominal Composition of Inconels. . . . . . . . . . . . 3-37

3-19 Moximum Impurity Content of Zircaloy Alloys . . . . . . . 3-38

3-20 Sources and Quantities of Non-High Level Fuel

Reprocessing Plont TRU-Wostes . . . . . . . . . . 3-39

3-21 Assumed Distribution of Fission Praducts and Tronsuranium Isotopes to Atmosphere, Primary Holding Pond, and

Burial Ground . . . . . . . . . . . . . . . 3-43 


\section{LIST OF TABLES}

(CONT.)

4-1 Existing DOE Defense-Related Transuranic Wastes . . . . . . . 4-3

4-2 Physical Charocter istics of DOE TR!.! Wastes . . . . . . . . . . 4-4

4-3 Estimated Composition of Laboratory Trash . . . . . . . . . . . 4-6

4-4 Estimated Composition of Line-Generoted Trash . . . . . . . . 4-7

4.5 Ronk Ordering of Waste Forms by Volume for Wastes Stored of ldaho frorri Septernber 1, 1971, to December 21, 1976, . . . . 4 4-11

4-6 Fank Ordering of Waste Forms by Weight for Wastes Stored a luaho from September 1, 1971, to December 21, 1976. . . . . 4-12

4-7 Kank Ordering of Woste Forms by Plutonium Content for Wastes Stored at Idcho From September I, 197I, to

December 3i,1976.................. 4-13

4-8 Estimated Averoge Composition of Combined Retrieved and Stored TRU W'aste .............. . . . . ló

4-9 Isotopic Composition of Weopan Plutonium . . . . . . . . 4-19

4-10 Isotopic Composition of Heat Source Plutonium . . . . . . . 4-20

4-11 Producers of Defense TRU Woste by Cotegory . . . . . . . . . . 4-22

4-12 Transuranic Content of Idaho and Sovannah Fiver TRU

Woste in Retrievable Storage . . . . . . . . . . . . 4-23

4-13 TRU Waste Information for Fiscal Year $1978 \ldots$. . . . . . . 4-31

5-1 Brief Description of Candidate Solid Waste Processing Concepts ......................... 5-11

5-2 Incineroiors Used for Combustion of Radioactive Solid Wastes . . . . 5-lä

5-3 Processes Under Development by DOE for Combustion of Radioactive Combustible Solid Waste . . . . . . . . 3-16

5-4 Copsule Descriptions of Combustion Processes. . . . . . . . . 5-21 


\section{LIST OF TABLES}

(CONT.)

Table

Page

5-5 Comporison of Combustion Technologies: Pretreatment. . . . . . . 5-22

5-6 Comparison of Combustion Technologies: Feed Systems. . . . . . . . 5-23

5-7 Comparison of Combustion Technologies: Primary Combustion. . . , , 5-24

$\supset-8$ Comparison of Combustion Technologies: Secondary Combustion. . . . 5-25

5-9 Comparison of Combustion Technologies: Primary Residue

Choracter istics and Handling ............... 5-26

5-10 Compar ison of Combustion Technologies: Off-Gas Treatrient . . . . 5-27

5-11 Compar ison of Combustion Technologies: Secondary Wastes

From Off-Gas Treatment . . . . . . . . . . . . 5-28

5-12 VR Evaluation Factors . . . . . . . . . . . 5.39

5 -13 Niojor Direct Copital Costs ............... . . 5-41

5-14 Mojor In-plant Opereting Costs ......... . . . . 5-42

$6-1$ Fixation of Liquid hastes Using Sorbents . . . . . . . . . . 6-3

6-2 Waste Form and Immobilization Agent Leachi Rotes. . . . . . . . 6-11

6-3 Conpor ison of Cement. Ureo-Formaldehyde Resin, Bitumen,

Polyester Resin and Gloss When Used as Solidification Agents . . . . 6-12 


\section{LIST OF FIGURES}

Figure

Poge

I-I TRU Waste Form Criteria Development Program. . . . . . . . 1-7

1-2 TRU Waste Form, Container and Packoge Criterio Evaluation

Nethociology .......................

2-1 Nuclear Fuel Cycle. . . . . . . . . . . . . 2-6

2-2 Fate of Transuranics in LWR Plutonium Recycle Flowsheet . . . . 2-7

3-1 Chart of Nuclides Showing Production of Transuronics . . . . . 3-2

4-1 Histogrom of Pu Content in Drums Stored at Idaho from

September 1, 1977 to December 31,1977 .......... 4-24

4-2 Histogrem of Pu Content in Boxes Stored of loaho from

September 1, 197i to December 31, $1977 \ldots$. . . . . . . . 25

4-3 Histograrrs of heopon and Heat Source Plutonium Content in 55-Gollon Drums Produced by Savannah River from

July 1, 1974 to June $31,1977 \ldots$. . . . . . . . . . . . 27

5-1 Treotment Options for "As Generoted" TFUU Woste . . . . . . . . 5-2

5-2 Volume fieduction of General Trash . . . . . . . . . . . 5-7

5-3 Options for Rodioactive Liquids and Uther Wet Waste Treatment . . . . 5-32 


\section{PREFACE}

The Nuclear Regulatory Commission is developing regulations governing the manogement, handling and disposol of tronsuranium wastes as port of its oversil waste management program. Numerous subtasks hove been identified which require completion before meaningful regulations can be proposed. This report wos prepored by TERA Advanced Servizes Corporation (TERA) to assist Lawrence Livermore Laboratory (LLL), prime controctor to the NRC, in the development of the technical dato bose necessory to support regulotions perfaining to transuranic wastes.

This report, "Transuranic Contaminated Woste Form Characterization and Dato Base," outlines the sources, quantities, charocteristics and treatment of tronsuranic wastes in the United States. This document serves os part of the data base necessary to complete preparation and initiate implementation of transuranic wastes, waste forms, waste contoiner and packaging standards and criteria suitable for inclusion in the present NRC waste management program. No attempt is mode to evaluate or analyze the suitability of one technology over another. indeed, by the nature of this report, there is little critical evaluation or analysis of technologies becouse such onalysis is only appropriate when evaluating a particular application or transuranic waste strearns. Due to fiscal restriction, the dato base is developed from a myriod of technical sources and does not necessarily contain operoting experience and the current status of all technologies. Such on effort was beyond the scope of this report.

Comments, elorifications or improved data should be directed to TERA's Berkeley office. 


\section{I.0 INTRODUCTION}

The disposal of any type of hazardous material, whether it be nuclear or nonnuclear, should involve the permanent removal of the material from man's biosphere. This can be accomplished either by converting the hozordous moterial to nanhozordous material or by disposing of it in such o woy that it cannot offect man's enviroriment.

Until now": woste manogement strotegies have seriously underestimated the significance of the waste form by concentrating on the isolation systerr. In sharp controdistinction to the latter, the waste form offers the pussibility of experimental verification, on well-estoblished scientific principles, for geological scole time periods. Furthermore, the use of resistant minerals as the model desirable hosis hos not only scientific significance, but special value in public interpretotion.

A recent report by the Notional Research Council has summarized the important consensual findings regarding the olternative solid forms available for waste solidificotion. 75

- The chaice of waste form must be made by determining the age of the waste and the final hast rock.

- Excellent mineralogical and geological models exist which demonstrate the survivol of specific phases incorporoting; particular ions (including the octinides) in o very wice variefy of neor surfoce ombients.

- The existence-theorem of a "safe" solid waste form in a system must be estobiished within the scieritific community. This is the only route to getting public acceptance.

- The concept of "demonstrotion" of any system will requiro 20 to 30 years as a minimum, ano is obviously too long to defer any policy decisions on ruclear power.

- The use of a "Codillac" madel of a mineral-imodeledceramic, cooted with $\mathrm{Al}_{2} \mathrm{O}_{3}$ and/or $\mathrm{Si}_{\mathrm{C}}$ and embedded in o metol matrix, is likely to be mast imporiant as $n$ test cose. 
- Once the cost becomes evident, especially for DOE (or other old) wastes, the madified Oak Ridge super-grout process, used on-site, will appear increasingly attractive.

It has been suggested that standards for occeptability of risk in the landling of nuclear waste disposal should be compared with the risks society is willing to take with other waste forms of toxic substances. The form of the waste has a tremendous impoct on its ultimate disposal and also its impact on future generations. In evaluating the impoct of TRU waste, the following concepts should be considered:

- Nuclea waste is not os persistent as some forms of chemical waste (e.g., mercury, arsenic or other heavy metols)

- Risks are associated with all aspects of existence

- Costs to raduce the risks of radioactive waste mist be justified in compurison to costs to reduce other forms oi risis

The current state-of-the-art technology is bosed ipon a "defense-in-depth" philosophy where the woste, waste form (includir. $\mathrm{gret}$ treatment and imrnobilization), and the waste container make up a waste package which is fur ner isoloted from mon and the biosphere by the surrounding geologic media and othei engineered barriers. In the rresent TRU waste manaçement program, the wastc form and wasie container sre evaluated as a "woste package." Thus it is important to identify the different woste forms which a: s utilized and are being propused for TRU waste and to document their characteristics in a dato base for use in future studies.

\section{1.i TRANSURANIC (TRU) CONT ANIINATED WASTES ${ }^{2,7}$}

The transuranium radionuclides are those nuclides with atomic numiers from 93 to 103. inclusive. Table $1-1$ gives the atomic numbers, names and chemical symbols of this group of elements. No known nuclides of the transuranium elements are stade. In general, the higher the atomic number of the element. the shorter the half-life. 


\section{TABLE $1-1$}

TRANSURANIUM ELEMENTS

$\begin{array}{clc}\begin{array}{c}\text { Atomic } \\ \text { Number }\end{array} & \begin{array}{c}\text { Element } \\ \text { Nome }\end{array} & \begin{array}{c}\text { Chemical } \\ \text { Symbol }\end{array} \\ 93 & \text { Neptunium } & \mathrm{Np} \\ 94 & \text { Plutonium } & \mathrm{Pu} \\ 95 & \text { Americium } & \mathrm{Am} \\ 96 & \text { Curium } & \mathrm{Cm} \\ 97 & \text { Berkelium } & \mathrm{Bk} \\ 98 & \text { Colifornium } & \mathrm{Cf} \\ 99 & \text { Einsteinium } & \mathrm{Es} \\ 100 & \text { Fermium } & \mathrm{Fm} \\ 101 & \text { Mondelevium } & \mathrm{Md} \\ 102 & \text { Nobelium } & \mathrm{No} \\ 103 & \text { Lowrencium } & \mathrm{Lw}\end{array}$


Plutonium is the best known of the tronsuronium radionuclides. It is commonly helpful to compore the properties of this group of rodionuclides to plutonium. This group of radionuclides is highly rodiooctive. They have o high specific activity, i.e., there are many curies, $\mathrm{Ci}$, of rodiooctivity for each gram of nuclide.

The transuranium elements are normully produced by neutron irrodiation of uranium or higher otomic number elements in a nuclear reactor. Additionally, iransuranium radionuclides are produced in thermonuclear explosions and by occelerotors. The general chorocteristics of the tronsuronium radionuclides cre high specific octivity, short spontaneous fission half-lives, and the lorge number of $X$-ray and garnma-ray photons emitted per disintegration of the iransuranium radionuclides.

Most transuranium radionuclides emit alpho particles. Miany also emit neutrons and some emit beto particles. Most particle emissions are accompanied by $X$-ray or gamma-ray emissions of re latively law energy, usually a few tens of kilovolts. Of the 46 known isotopes of elements 93 ( $N p)$ through $99\left(E_{5}\right)$ with half-lives greater than one day, 30 are alpha emitters, nine decay by beta emission, five capture orbital electrons, and two undergo spontaneous fission os the primary modes of decoy. ${ }^{2}$

Reprocessing of spent fuel elements atfempts to remove plutonium, but since the separation is not complete, the resulting high-activity liquids still cantain some plutonjum as well as other transuranics. Lijkewise, transuranic contamination of low-activity wastes occurs when the transuronic materiols ore handled or processed, which is primarily af federal focilities involved in R\&D and nucleor weapons production. 5 
Transuranics are persistent in the environment and, as o general rule, are strongly retained by soils. They ore not easily transported through most food chains, although some reconcentration does toke ploce in the oquatic food choin. They pose only a slight biological hazard to humans upon ingestion because they are weokly absorbed from the gastrointestinal troct. A greater hazard results from inhalation since they behave like normal dust and froctionate accordingly. Production of an odverse health effect in the lung, or elsewhere, depends on the particle size and solubility of the inhaled contaminated dust. Upon entry into the bloodstream (either by ingestion or inhalation), TRUs will then readily cccumulcte in bone and liver tissues, and can significantly increase the risk of cancer. ${ }^{3}$ Appendix $B$ presents a more complete overview of TRU radiaisotopes.

Land burial has been used for the disposal of radioactive wastes since the inception of nuclear weapons research in the 1940's. The term "burial", as used in this report, refers to the placement of waste at relatively shallow depths in earth materials, with no intent or provision for ready retrievabiiity of a loter date. As such, it is distinguished from geologic disposal and storage techniques by the proximity of the waste to the surfoce of the earth and the surrounding biosphere. The migration or dispersal of the radioactive and other toxic materials in the waste must be kept to some minimum or occeptable level.

Initiolly, burial grounds operated by the U.S. Atornic Energy Commission (AEC) handled and disposed of wastes generated by AEC facilities as well as wastes from private industry. However, during the 1950's much of the waste generated vithin private industry was delivered to several private companies for sea aisposal. Growing pressures ogainst this technique caused the AEC to encourage the use of burial focilities at the Oak Ridge National Laborotory in Oak Ridoe, Tennessee, and the National Reactor Testing Station in Idaho Folls, Idgho, untif private burial grounds could be established. In 1962 a commercial burial ground was opened in Beotty, Nevado, and in 1963 a similar site wos opened in Moreheod, Kentucky. In Moy, 1963, the AEC discontinued its policy of occepting wastes from privote industry. By $|97|$, six commercial sites were licensed for the handling and disposal of radioactive waste. ${ }^{5}$ 
At present, radioactive wastes in all categoxies other than "high-level waste" (produced during the first stage of fuel reprocessing) ore buried at both DOE and commercial buriol sites.

Notably with the monagement of transuranic waste, the over lap between preserit practice and older practices makes it difficult to clearly identify the problems. There is some concern about the radiologicol heolth similarities of seepoge pits and land burial sites, particularly with respect to migration of radioactive elements in the soil.

It is assumed that transuranic wostes that have excessive unit size or radiation level for receipt at the federal repository will be stored or buried on-site in a pofentially retrievable form seporate from nontransuranic wastes. These types of tronsuranic wostes are generoted predominantly of DOE or commercial plants for reprocessing of spent fuel and, as generated, are primarily a hazar f becouse of their fission product content.

\subsection{TRU WASTE MANAGEMENT PROGRAM}

The development of the NRC's TRU Waste Monagement Program requires that extensive informotion ond o dota base be estoblished which can be utilized to develop woste classification, form and container requirements for transuranic contaminated (non high-level) waste requiring disposal in a deep geologic repository.

Figure 1-1 presents a proposed scheme for the TRU waste form criterio development program based upon the development of an extensive doto base. As can be seen from this figure, TRU wastes are generated from military and DOE activities, the commercial sector and other miscellaneous sources. In order to develop the TRU dato bose and initiate work based upon this data base, it is necessary to identify the sources af TRU waste, develop the inventory, and identify the various forms of this waste. This information is then utilized to characterize the waste. Based upon this characterization and the develapment of a waste classification scheme far TRU waste, it is then passible to identify the TRU wastes which require deep geologic disposal. 


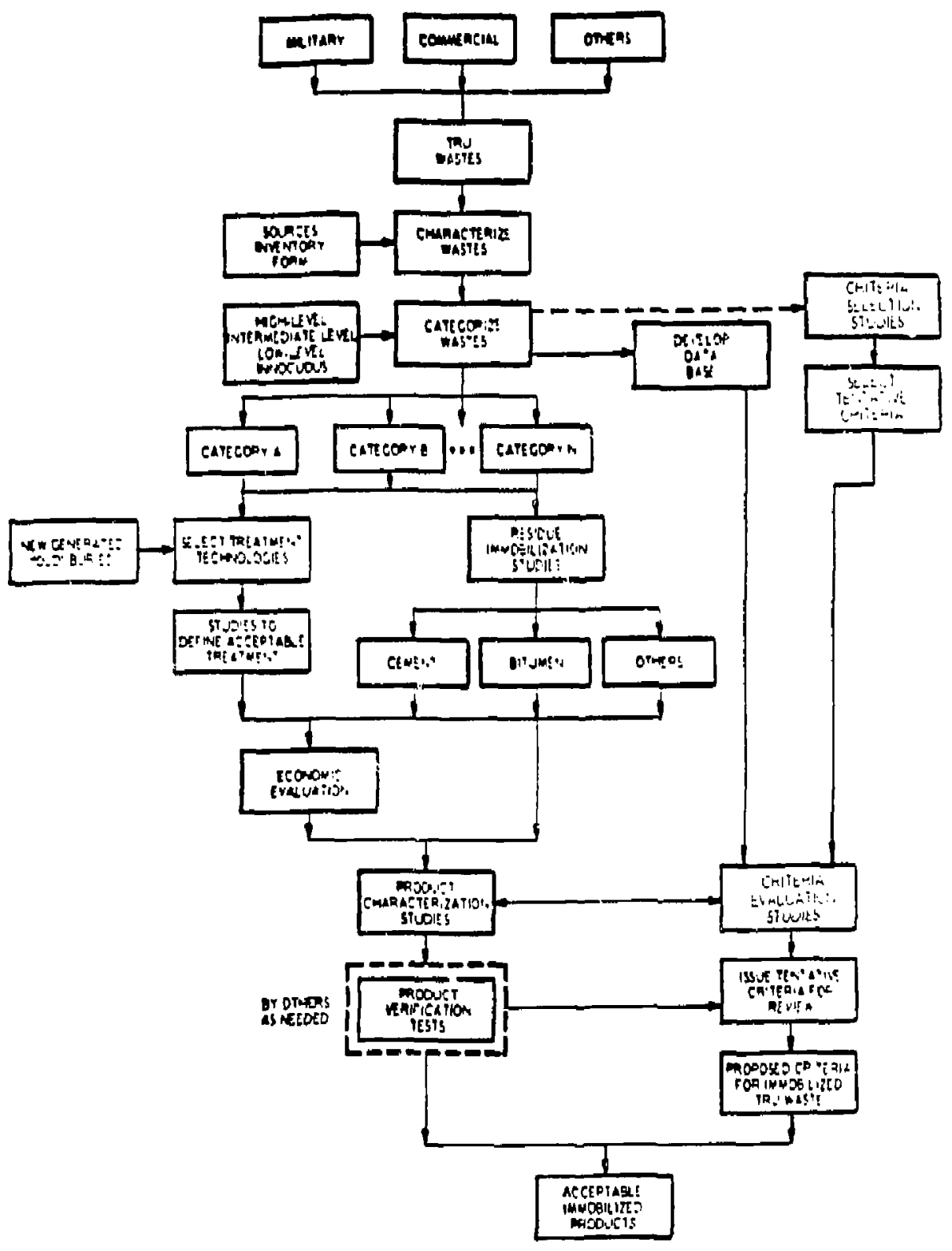

FIGURE |-I

TRU WASTE FORM CRITERIA

DEVELOPMENT PROGRAM 
After the initial work, general criteria selection studies would be initiated and the doto base would be revised to develop the base case scenorios which would be utilized for all initial studies and program evaluation.

Utilizing the various categories defined in the waste classificotion study 7,15 (presently three ${ }^{*}$ ), it is necessory to examine and evaluate the treatment technologies ovailable to process the os-generated TRU wostes. Such evaluations should primarily review the generoted waste form of the contominated material and determine if means to reduce the volume, reduce the combustibility possibilities and other similar technical considerations are appropriate. Simultaneously, various means should be exomined to immobilize the residue that results from such treatment technologies or the unprocessed waste material. It is noted that not only newly generoted wastes but old buried wastes shouid be considered. With the identification of the new technologies and means of immobilizing the residue, the woste container is defined. This container is provided to allow ease of transportation and handling before disposal. Based upon extensive modeling and other evoluotions, tentotive criterio would then be developed for the waste form in the finol immobilized motrix. Such criterio might be either qualitotive or quantitative in nature and would reflect the present ovailable technology as well os hove means to delermine the applicobility of new technologies as they ore developed.

With the identification of these technologies and the evaluotion of their opplicability, an ec. Imic analysis would be performed to detern.ine the cost impoct of the criterio. Wrile Figure $1-1$ indicates the general outline and approach of the program, the problem of defining the TRU waste form and potential packoge options is mare complicated inasmuch os the number of porameiers which are being evaluoted is quite large. Figure $1-2$ presents o schematic indicating the vorious mojor parameters of this program and the interactions which must be considered in the development of criterio and a methodology to evaluate the impact of such criteria on proposed technicol solutions to the handling of TRU wastes.

\footnotetext{
Three classes of TRU waste would be expected: Class $C$ requiring no special hardling (normal sanitary land fill operations); Class B requiring shallow land burial as low-level radwoste; and Class $A$ requiring deep geologic disposal.
} 


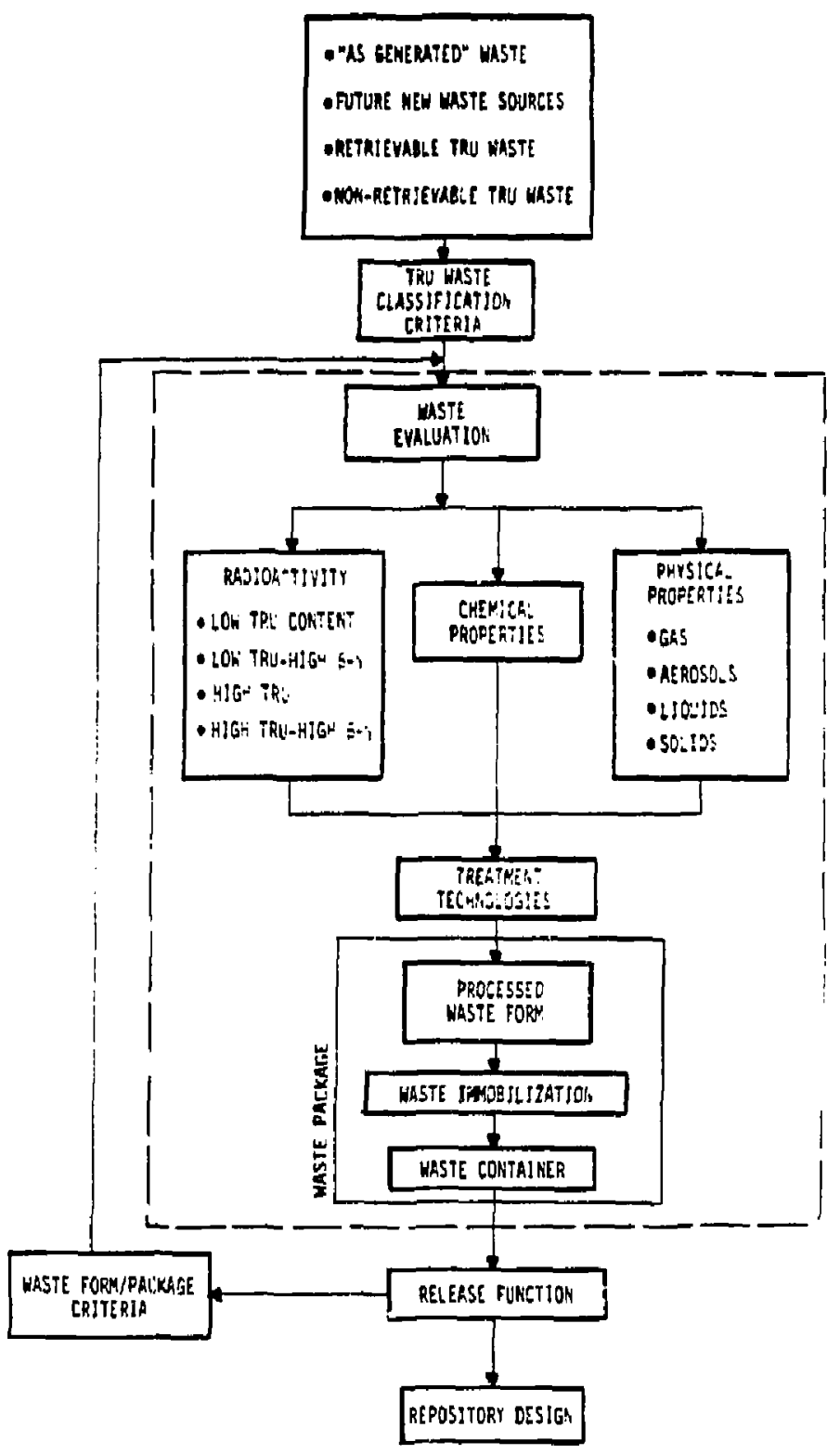

FIGURE $1-2$

TRU WASTE FORM, CONTAINER AND PACKAGE CRITERIA EVALUATION METHODOLOCY 


\section{BACKGROUND}

This section provides a brief overview of the TRU contamiriated waste problem, establishes the necessory bockground information for the development of the TRU waste forms characterization dala base, and briefly reviews TRU contominoted waste sources, inventory, and containers.

In the early days of the nuclear age, little thought was devoted to the disposol of radioactive contaminaled material since it was secondary to the main task at hand. Indeed, it appears that the present practice of shallow land burial evalved from the use of sanitary landfill burial techniques to dispose of various wostes on-site, where the moteriols were generoted. Loter, os it become apporent thot the notional laboratories would become permanent federally-supported facilities, increasing attention was given to waste disposal problems, especiolly land burial. As the research, development and production programs were expanded and modified, the waste materials and used equipment to be buried secame much more varied and difficult to manage. Solid radioactive waste had often been buried in the most accessible and convenient, vacant place, without a great deal of thought for the long-term consequences. Fortunately, the omount of radioostive material was not large of that time. Indeed, the tronsuranium (TRU) elements were very strictly conserved and, at first, solid waste containing separated fission products wos not o serious land burial problem. Wartime pressures for production and lack of knowledge or understanding led to siting and operational practices that, in many situations, ore unsatisfactory by present-day standords. ${ }^{5}$

\section{I TRU CONTAMINATED WASTE CLASSIFICATION}

As part of the regulations governing the manogement and disposal of radioactive waste, the NRC is developing a rodiaactive waste classification system. The clossificotion system is not intended to reploce existing practices, criteria, or regulations relating to the generation, pockaging, handling, or traisport of rodioactive material; but rather, it will provide guidelines regarding the ultimate 
disposition of waste containing specific concentrotions of individual rodionuclides, including tronsuronic rodionuclides. 15 As stoted previously, the current regulatory position (os well as definition of TRU voste sources and inventory) is based upon a requirement for retrievable storage of all waste with a TRU content of 10 manocuries per gram or above.

During the regulatory process, issue was taken with some practical considerotions in implementation of the 1974 AEC rule--particularly the 10 nonocurie per grom guideline. The general opinion was that the 10 nanocuries per grom limit was not justified and that the proposed rule shou'd be supported by an economic impact analysis that showed a positive cost-benefit ratio. Further, it was noted that no practicable nondestructive assay method existed for the guideline. Other foctors identified included the difficulty, expense, and personnel exposures in ferforming assays. Additionally, it was felt thot the forms, volumes and categories of wastes subject to fedaral management under the proposed rule posed significant logistical problems. Modifications or alternatives to the 10 nanocurie per gram guideline were olso suggested.

Upon review, and comments received from interested parties, the NRC staff determined that the proposed rule was unworkable and initiated development of regulotions which would govern the disposal of all radioactive waste--not jusf TRU-contaminated waste. The NRC initiated a study to provide a broud analytic bose for a waste disposal classification system, providing a foundation for the forthcaming regulations and accompanying environmental impact statements. 15

In an earlier report, this methodology was examined for application strictly to TRU waste. ${ }^{7}$ The purpose of the TRU functional definition is to provide an iriterpretation of the basic NRC criteria for waste management in terms of requirements for TRU waste to be satisfied. The objecfives of this classification system are:

- To clossify wastes occording to their requirements for safe disposal 
- To ocdress the concerns of the public, and

- To implement the system withour undue burden on those directly offected by it

A methodology was developed to provide on occeptable meons of determining levels of TRU concentration which require deep geologic disposal (Closs A waste), angineered containment, e.g., shallow-land burial (Class $D$ waste), and disposal as nonradioactive waste (Class $E$ wuste). However, the exact interface points hove not yet been established-except to the extent that woste at a $10 \mathrm{nCi} / \mathrm{g}$ level will obviousiy not require deep geologic uisposal while a volue of $100-1000 \mathrm{nCi} / \mathrm{cm}^{3}$ appears o more likely interfoce range. The exact values are subject to further modeling refinement, andysis and review os well as evaluation of compliance with EPA criteria, DUE practices, and other regulatory concerns. Based upon the present evaluation, the limits of Table 2-1 appear appropriate os guidelines for limits of disposal by shallow land burial. These limits, when compared with the TRU isotope detection capability, appecr within the working range for various methuds or combinations of detection methods. ${ }^{7}$ Similarly, Table 2-2 presents limits for THU waste requiring disposal by shallow land burial.

\subsection{SOURCE OF TRU CONTAIVIIIATED WASTE}

The source of the largest potential radialogical hazard associated with wostes from the nuclear fuel cycle is the HLW stream from fuel reprocessing, or the spent fuel assemblies in the absence of reprocessing (see Figure 2-1). A second category of solid wastes (see Figure 2-2), which includes a wide variety of materials such as cladding hulls and miscellaneous wostes from fuel reprocessing and refabricotion steps, and which are referred to os tronsuranic (TRU) wastes, represents a problem comporable in importance to that posed by isolotion of the actinide component of the HLW. Most of this waste comes from the Deportment of Energy's reactors and facilities, cammercial nuclear power plants, and federal (military) and commercial nuclear fuel cycle octivities-mainly fuel fobrication and reprocessing facilities. No commercial reprocessing facilities are currently operating, but DOE has four reprocessing facilities either in operation or on standby, 5 
TABLE 2-1

TRU ISOTOPIC CONCENTRATION LIMIITS

FOR \$HALLOW LANU BURIAL ${ }^{7}$

\begin{tabular}{|c|c|c|}
\hline Isotope & Interfoce ${ }^{\mathrm{Ci} /} / \mathrm{cm}^{3}$ & $\left(\mathrm{nCi} / \mathrm{cm}^{3}\right)$ \\
\hline$N p-237$ & 0.02 & $(20)$ \\
\hline Pu-238 & 0.4 & $(400)$ \\
\hline Fu-239 & 0.1 & $(100)$ \\
\hline$P u-24 U$ & 0.1 & $(160)$ \\
\hline$P u=241$ & 5.900 & $(5.900,000)$ \\
\hline$P u-24 L$ & 0.1 & $(100)$ \\
\hline$A m_{1}-241$ & 0.4 & $(400)$ \\
\hline Am-24j & 0.3 & $(300)$ \\
\hline $\mathrm{Cm}-242$ &.- & .. \\
\hline $\mathrm{Cm}-244$ & 13 & $(15,000)$ \\
\hline
\end{tabular}

Nioximum aliowable concentration values for U-235 anc' $U .238$ ore 0.03 and $0.03 \mathrm{LCi} / \mathrm{cm}^{3}$, respectively. 


\section{TABLẼ 2-2}

TRU ISOTOPIC CONSENTKATIONS REQUIRING DISPOSAL BY SHIALLOW LAND BURIAL ${ }^{7}$

Nuclide

Np. 237

Pu- 238

Pu-239

$\mathrm{Pu}=240$

Pu-241

Pu-24L

Am-241

Am-243

$\mathrm{Cm}-242$

Cm-244 $\underline{\left.. C i / \mathrm{cm}^{3} \ln C \mathrm{Ci} / \mathrm{cm}^{3}\right)}$

$5.4 \times 10^{-4}(0.54)$

$3.4 \times 10^{-4}(0.34)$

$3.0 \times 10^{-4}(0.3)$

$3.0 \times 10^{-4}(0.5)$

$1.5 \times 10^{-2}(15)$

$3.1 \times 10^{-4}(0.31)$

$9.2 \times 10^{-4}(0.92)$

$0.2 \times 10^{-4}(0.82)$

$2.4 \times 10^{-2}(24)$

$1.5 \times 10^{-3}(1.5)$ 
i

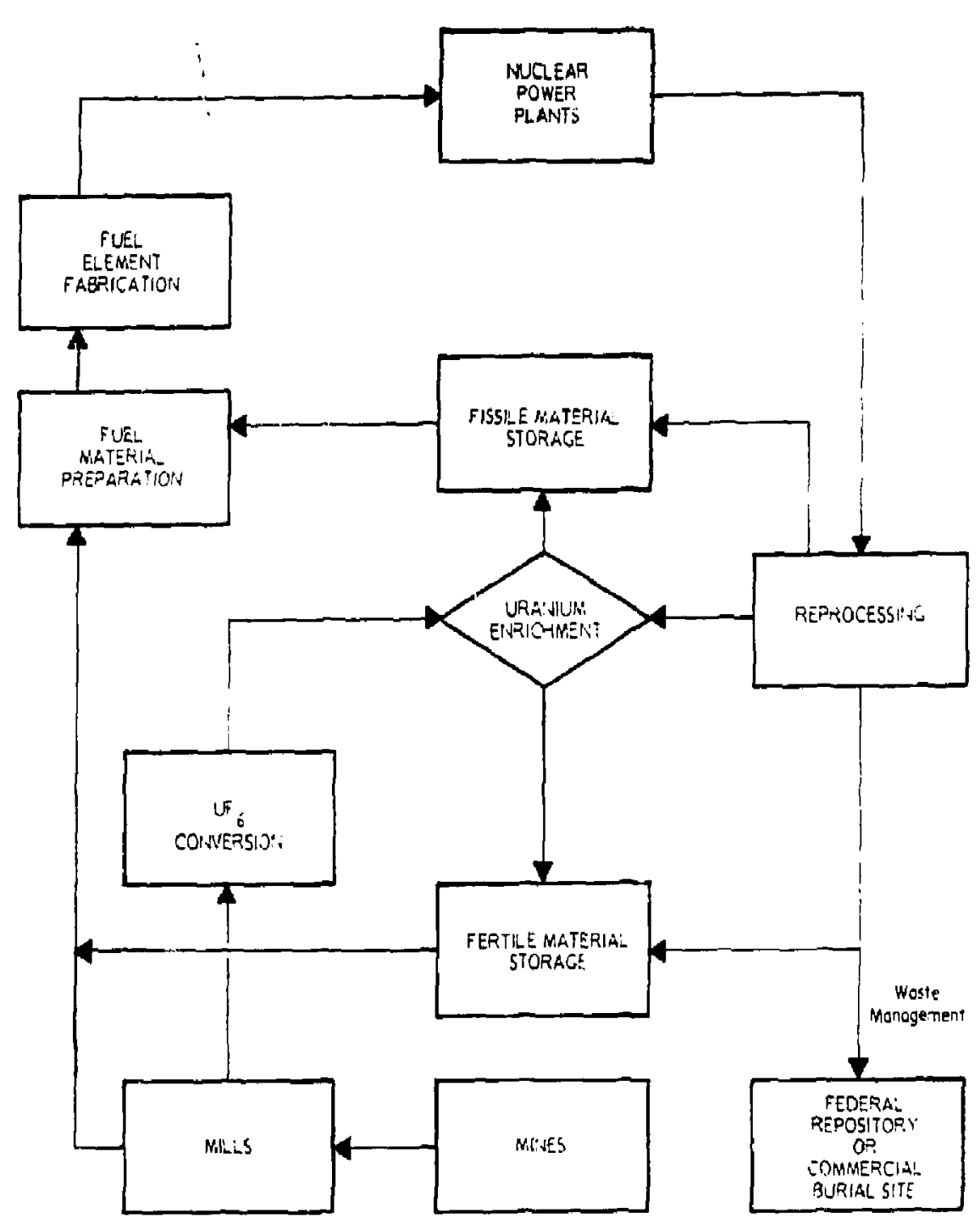

FIGURE ?-1

NUCLEAR FUEL CYCLE 

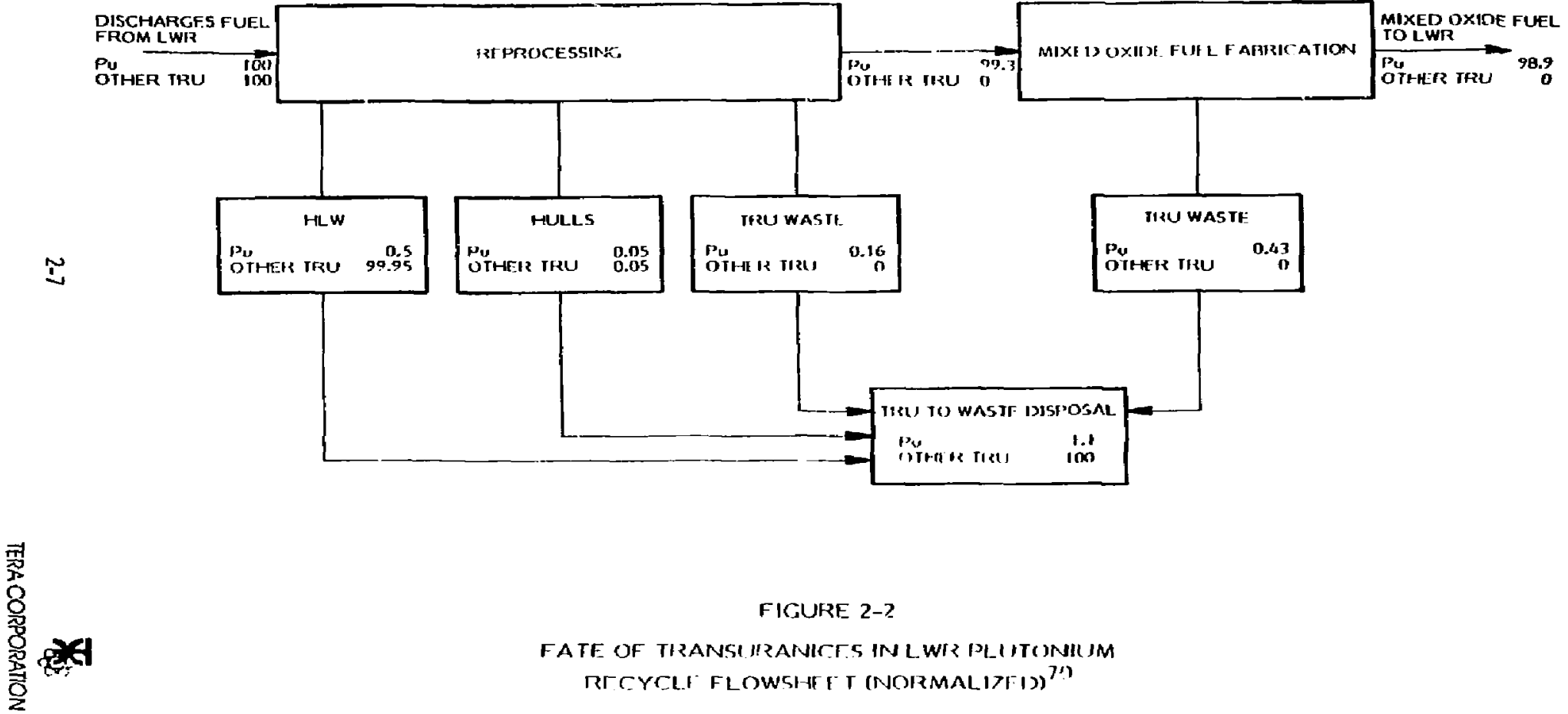

FIGURE 2-?

FATE OF TIRANSIIRANITES INLWTR PLIITONIUMM RECYCLF FLOWSH I T (NORMALIZFI)) 
High-level liquid waste contains many fission products and small amounts of transurar.ics, such os plutonium, which ore not recovered during the reprocessing operotion. Besides being found in high-level woste, transuranic (TRU) materials in vorious concentrations are also found in other waste, it is generoted by plutonium fuel fabrication and ivel reprocessing facilities and also by lobora. tories which use tronsuranic slements. This waste generally consists of expendable iterns such as absorbent paper, clathing, gloves, plastic bags and equipınent; ion exchange resins or filfers from effluent treatment systems; and fuel cladding hulls which remain after reprocessing. 5

To odequately define the sources of TRU waste in the U. S., it is necessory to identify oll present inventories of such wastes, os well os the facilities which generote or may generale such wastes in the future. In mony coses, it is difficult to clearly define the TRU wastes generoted withrut identifying tice overall radioactive woste generation rotes and characteristics $0^{*}$ the waste handled at each porticular focility.

At present only eight DOE focilities ore burying or storing TRU contominated waste. These sites and the quontity of waste buried or stored ore given in Toble 2-3. The list of DOE facilities generating TRU waste is substantially larger and is presented in Table 2-4. This waste con and does include almos 1 anything used in the reprocessing of spent tuel fabrication of nuclear weopons, and 0 myriad of R\&D a ivities.

The following information represents estimates of sources of tronsuronium soitc wostes in the United States and an evoluation of the quantities of these wastes. It is assumed that transuronium solid waste hos tronsuronium alpho radioactivity of greater than $10 \mathrm{nCi} / g$ (nanocuries per grom). This assumption has the effect of excluding most of the very large volume of waste that is generated within the normally occupied work areas of transuranium processing and fabrication plants. It is ossumed that wastes contoinin ibsis than $10 \mathrm{nCi} / g$ of transuranium nuclides will continue to be buried on site or shipped, generally as Low Specific Activity $(\mathrm{LSA})$ or Type A Qunntity material, to burial grounds (either commercial or DOE sites). 5 
CUMULATIVE VOLUME OF DOE-GENERATED TRU-CONTAMINATEO SOLID WASTE* BL'RIED AND/OR STORED AT DOE SITES ${ }^{5}$

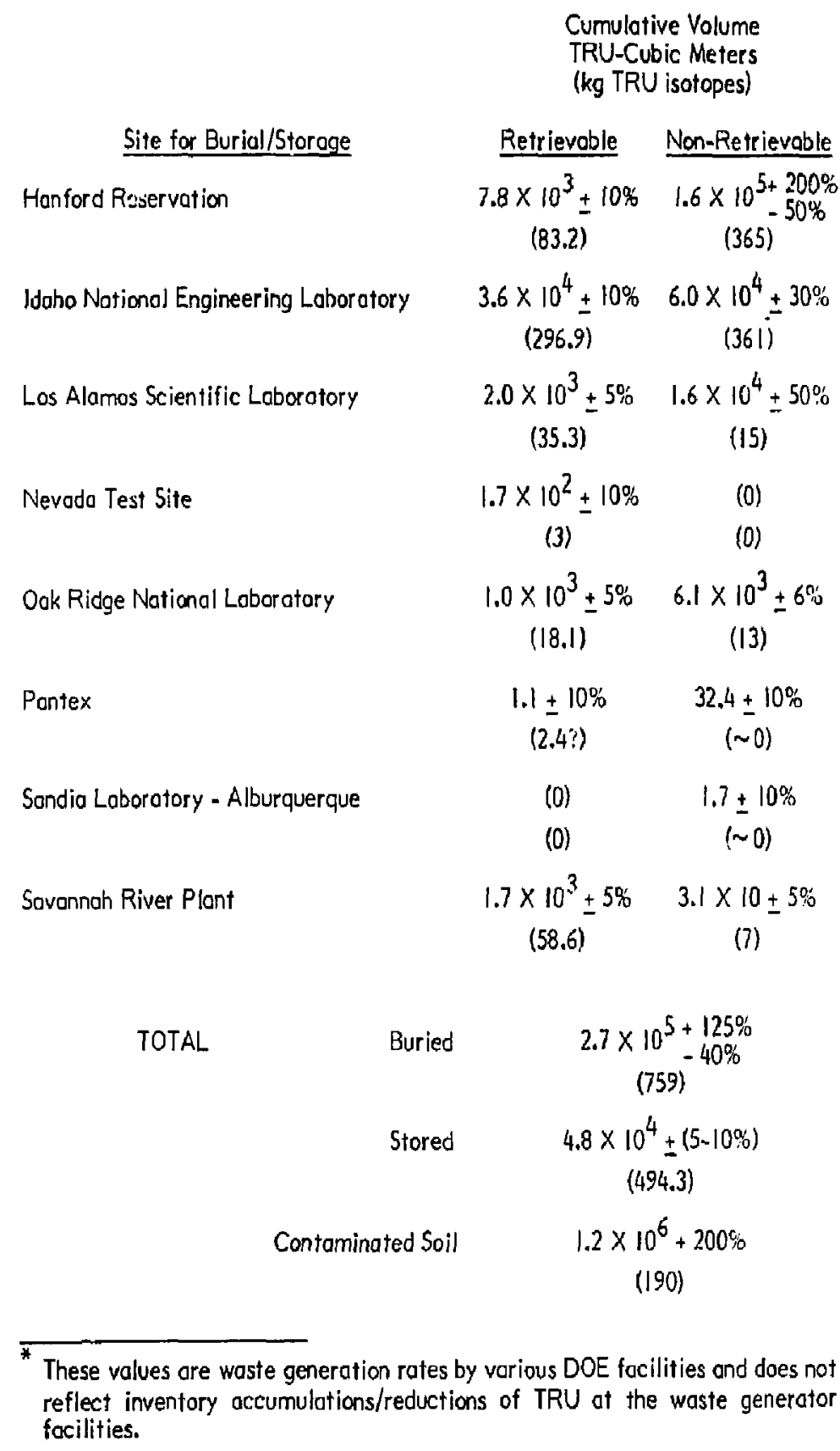


TABLE $2-4$

DOE FACILITIES AND FACILITY OPERATORS GENERATING TRU CONTAMINATED WASTE ${ }^{5}$

\begin{tabular}{|c|c|}
\hline Los Alamos Scientific Loboratory & Brookhaven Notional Loboratory \\
\hline $\begin{array}{l}\text { Loveloce Inhalotion Taxiçology } \\
\text { Research Instifute }\end{array}$ & $\begin{array}{l}\text { Battelle Memorial Institute } \\
\text { EG\&G Idoho, Inc. }\end{array}$ \\
\hline $\begin{array}{l}\text { Mound Focility } \\
\text { Pontex Plant }\end{array}$ & $\begin{array}{l}\text { Nevada Test Sife } \\
\text { - Mercury Naeg Soils Laboratory }\end{array}$ \\
\hline Ames Laboratory & Onk Ridge Notionol Loboratory \\
\hline Rocky Flats Plant & Poducah Goseous Diffusion Plont \\
\hline $\begin{array}{l}\text { Atamics International } \\
\text { (Sonta Susana. CA) }\end{array}$ & $\begin{array}{l}\text { Bettis Atomic Power Laboratory } \\
\text { Novol Reactors Facility }\end{array}$ \\
\hline $\begin{array}{l}\text { Sondia Laborotory } \\
\text { Albuquerque }\end{array}$ & Pocific Northwest Loborotory \\
\hline Lawrence Livermore Loboratory & Rockwell Hanford Company \\
\hline Lowsence Berkeley Loboratory & United Nuclear Industries \\
\hline $\begin{array}{l}\text { Argonne Nationol Loboi afory } \\
\text { - Eost } \\
\text { - West }\end{array}$ & $\begin{array}{l}\text { Westinghouse Honford Company } \\
\text { Sovannah River Plant }\end{array}$ \\
\hline
\end{tabular}


Up to the present time, commercially generated solid woste contaminated with transuranium (TRU) nuclides has been disposed of at commercial buriol grounds. TRU waste has been disposed of at five of the six commercial burial sites." This waste was generated by the commercial LWR industry, os well as Department of Energy (DOE) and its predecessor AEC and ERDA. These sites have occepted wastes generated in the fuel cycle, primarily fuel fobrication and spent fuel reprocessing, os well os from numerous miscellaneous R\&D octivities and small commercial uses of TRU rodioisotopes. The present inventory of TRU-contaminated waste is limited primorily to DOE-generated waste (shipments now terminated) and R\&D fuel fabrication activities involving plutanium. The NRC does not have records on the volume of commercial tronsuranic contaminated waste buried at commercial shallow land burial sites, but estimates that about 123.4 kilograms of plutor um were buried at five of the six sites through $1977^{5}$ (see Table 2-5). The best available information indicates that the cumulative DOE-generated TRU waste (through 1976) shipped to these commercial burial grounds contoined about 7.6 kilogroms of TRU isotopes.

The present (as of October 1, 1978) TRU inventory of contaminated wastes, soils and sediment is os follows:

$\begin{array}{llr}\text { Retrievably stored - DOE } & 494 \mathrm{~kg} \text { TRU } & 4.8 \times 10^{4} \mathrm{~m}^{3} \\ \text { Previously buried - DOE } & 759 \mathrm{~kg} \text { TRU } & 2.7 \times 10^{5} \mathrm{~m}^{3} \\ \text { Contaminated soils and sediments - DOE } & 190 \mathrm{~kg} \text { TRU } & 1.2 \times 10^{6} \mathrm{~m}^{3} \\ \text { Previously buried - Commercial } & 123 \mathrm{~kg} \text { TRU } & \text { unknown }\end{array}$

Besides on inventory of presently buried/stored TRU-contaminated woste, it is important to project future waste generation rates and radioactivity levels to allaw policy makers on assessment vehicle to determine the impact of o proposed

\footnotetext{
Beatty, Nev.: West Valley, N.Y;; Maxey Flats, Ky.; Richland, Wasti.; Sheffield, III.; Barnwell, S.C. (no tronsuronic waste except smoll quantities of Am-24l at Barnwell).
} 


\section{TABLE 2-5}

CUMULATIVE WASTE INVENTOPYY AT COMGEERCIAL BURIAL SITES $(1977)^{5}$

\begin{tabular}{|c|c|c|c|c|}
\hline Site & $\begin{array}{l}\text { Total } \\
\text { Volume Buried } \\
\left(10^{3} \mathrm{~m}^{3}\right) \\
\end{array}$ & $\begin{array}{l}5 \mathrm{NN} \\
(\mathrm{kg})\end{array}$ & $\begin{array}{l}1974 \\
\text { TRU } \\
\text { (kg) }\end{array}$ & $\begin{array}{l}\text { TRU } \\
\underline{(k g)}\end{array}$ \\
\hline Beotty & 58.054 & 688.247 & 14.3 & 14.3 \\
\hline West Valley & 66.726 & 56.003 & 3.6 & 3.6 \\
\hline Morehead & 135.016 & 31.260 & 69.1 & $6 \% .1$ \\
\hline Richland & 16.238 & 83.235 & 12.7 & 23 \\
\hline Shetfield & 86.634 & 53.962 & 13.4 & 13.4 \\
\hline Bornwell & 142.873 & $456.863^{*}$ & -- & -- \\
\hline
\end{tabular}

*umulative through 1976 
rulemaking change. As indicated above, a total of 0.32 million cubic meters of TRU solid waste was in storoge ot DOE sifes as of October 1978. By October 1984, it is anticipated that the retrievable inventory will increase by o factor of nearly two, while the waste in burial sites will remain unchanged. Consequently, the change in total inventory up to 1984 represents an increase of about 15 percent. The commercial TRU waste inventory is not expected to increase significantly unless reprocessing of spent fuel becomes notional policy. A DOE analysis assumed only 280 cubic meters per year of commercial waste in the future. 5

TRU waste sources, and a discussion of woste inventory for both commerciallyand DOE-generatea waste, are oddressed in detail in Reference 5.

\subsection{TRU COINTANINATED WASTE CONTAINERS ${ }^{\prime \prime}$}

A waste container is defined as the drum, box, or canister which immediately surrounds the TRU waste. This includes any associated hardware, such os liners or spacers, internal to the container. A proper container and packaging design are the foundations of shipping and handling TRU waste material. The waste container and/or package must meet the requirements of the Department of Tronsportotion (UOT) and the NRC for tronsport tis the burial focilities. These regulations specify the mechanical properties of the waste package relative to applicable transport conditions. The severity of :hese conditions is related to the quantity of the specific radionuclides contained. These requirements are met either through container design (wall thickness) or protective overpacks. The regulations also specify thermal behovior of the woste package under normal transport, and hypothetical accident situations for packages contailing on excess of type $A$ quantities. Normal conditions are considered ambient temperatures of $-40^{\circ} \mathrm{C}$ to $54^{\circ} \mathrm{C}$, while under occident conditions the package is exposed to $802^{\circ} \mathrm{C}$ for 30 minutes.

TRU waste containers and radioactive waste containers, in general, have evolved with the nuclear ero. This evolution hos paralleled the development of growth in 
the industry and has basically filled a need as it arose. Indeed, only with the creation of the Department of Transportation in 1966, and the consequential assimilation of responsibility and authority in a single regulatory agency, hos the waste container testing, certification, and licensing effort stabilized. Even with DOT regulating radiooctive waste contoiners, of least 18 different waste containers have been or ore being used to dispose of commercial and DOEgenerated TRU waste. The current DOE regulation ${ }^{8}$ for handling of TRU contominated dry wastes requires packaging and burial/storoge in such a manner that the containers can be retrieved intact and remoin contamination-free for a 20-year period.*

Various criterio must be considered in the selection of a container for a voriety of TRU waste materials and functions. In cartain cases, the container may be used as a process vessel, i.e., in the case of solidifying wastes by using cements, urea-formaldehyde resins, bitumen or other similar materials. Contoiner desigri is important due to the requirements of transportation of solidified waste packoges, interim handling, depository design for disposal and consideration for retrievability, if this is deemed necessary. The container should provide radiation shielding, if required, and be of sufficient integrity to minimize tne probability of container breach due to hondling or tr ansportation accidents. The purpose of the container is to provide ease of handling, minimize personnel exposure and prevent loss of activity from the package prior to burial. The containers may also provide a barrier to radionuclide release from the waste form in burial; however, no credit has typically been given to the container once the waste package is buried. This is the result of a lack of a proven long-lived engineered waste container design. While such considerotions may be importont for non-TRU low-level woste, the long half-lives of some TRU radionuclides make such considerations meaningless over the time period of the consideration. If retrievability is a requirement, the period of retrievability must be considered in the container design life.

Presently proposed WIPP criterio only require a 10-year life. 
Design guidance for waste containers is rother limited to regulotions published in IOCFR - Parts, 20, 70, 71 and 73, 49CFR - i73.30! through 173.395, Regulatory Guide 7.4 "Leakage Tests on Pockoges for Shipınent of Rodioactive Materials:" Regulatory Guide 7.6 "Arceptable Structured Methods for Use i: Designing Lorge Guontity Packoges;" Regulatory Guide 7.8 "Lood Combinations for the Structural Anclysis of Shipping Casks;" and, ANSI N14.5 "Leakage Tests on Packoges for shipping of Radiooctive Noterials." Other standards are under development by a N14 standards group sponsored by the American Insurance .4ssociation concerned with various aspects of shipping radioactive materials.

A survey by DOE contractors revealed the extensive number of waste containers/packages utilized (see Tables 2-6 and 2-7). At present, more than 18 different packaging configurations are being used for interim storage of DOE low-level TRU wastes. $11,18,90$ Of these configurations only the DOT I7C steel drum and the $1.2 \mathrm{~m} \times 1.2 \mathrm{~m} \times 2.1 \mathrm{~m}$ DOT $7 \mathrm{~A}$ plywood box ore readily acceptable for direct shipment and isolation in the current design of WIPP. The proliferotion of waste packages currently in use is a direct result of efforts of the various woste generators to pockoge their unique TRU wostes into containers able to meet the 20-year retrievability requirements under the differing conditions of on-site waste processing and storage. Completing the criteria, development of standardized TRU waste containers will be difficult without established parameters with regard to waste form and interim and final storoge environment. In the selection of materials for construction of a particular packaging system, it is important to consider the characteristics of the system, giving special attention to extraneous foctors that may influence decomposition. Since these factors would be peculiar to a particular system, it may be impractical to offer hard and fast rules that would cover all situations. Table $2-8$ presents a compilation of various TRU waste pockoges in use."

The containers presently in use of various DOE and commercial focilities folt into three general categories: 114 -liter (30 gallon) and 208-liter ( 55 gallon) steel drums; large fiberglass reinforced polyester (FRP) plywood boxes and lorge carbon sleel boxes. These latter containers have capacities in the ronge of 0.23 - 
TABLE 2-6

RESULTS OF WASTE CONTAINER SURVEY OF DOE WASTE GENERATORS "

Type A Packages

I. Meiol Drums (DOT Regulation)

Spec. 5B (178.82)

Spec. 5D (178.84)

Spec. 6A (178.97)

Spec. 6B (178.98)

Spec. 6C (178.9\%)

Spec. 6J (178. 100)

Spec, 6K (178.101)

Spec. 6L (178.103)

Spec. 6 M (178.104)

Spec. $17 \mathrm{C}(178.115)$

Spec. $17 \mathrm{H}(178.118)$

Spec. $428(178.107)$

Spec. $42 \mathrm{C}(179.108)$

2. Fiber Drums

Spec. 2IC (178.224)

3. Wooden Boxes

Spec. $14(178.165)$

Spec. 15A (178.168)

Spec. $15 B(178.169)$

Spec, I5C (178.170)

Sper. I5D (178.17))

Spec. $19 \mathrm{~A}(178.190)$

Spec. 19B (178.191)

4. Fiberboord Boxes

Any Spec. 12 Series

(178.205 to 178.212)

(200 $\mathrm{lb}$ tesł minimum)

Spec. 23F (178.214)

Spec. $23 \mathrm{H}(178.219)$
Number of Users

3(208-L)

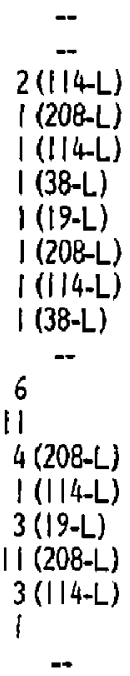

5

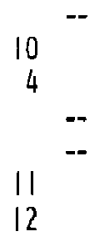

I (12A)

$12(12 \mathrm{~B})$ 


\section{TABLE 2-6}

\section{(CONT,)}

Type A Packages

Number of Users

\section{Cylinders}

Any 5 pec. 3 Series

Any Spec. 4 Series

$2(3 A, 3 A A)$

(178.47 to 178.58)

6. Spec. $55(170.25)$

9

\section{Spec. $7 \mathrm{~A}(178.350)$}

NOTE: 17 packnges were listed as being used by EFDA controctors under the Spec. 7 A clossificotion.
1) Cylinders for UF 6
(five sizes)
2) Strong Wooden Boxes
3) Steel Boxes
4) Fiberboord Boxes
5) Steal Drums
6) Berielex Box (neutron sources)
7) Concrete Voults 
TABLE 2-7

DOE WASTE CONTAINER SPECIFICATIONS ${ }^{11}$

Container Type

1) Steel Cylinder (UF ${ }_{6}$ ) (five styles)

2) Brookhoven's Concrete Voults

3) Argonne's Steel Box

4) ORNL's 7A Pockoge

5) Battelle Columbus Steel Box

6) Wooden Box

7) Wietal Drum

8) Mietal Drum

9) Nietal Drum

10) Metal Drum

11) Metal Drum

12) Metal Drum

\section{DOT Specification}

Spec. 7A

Spec. 7A

Spec. 7A

Spec. 7A

Spec. $7 \mathrm{~A}$

5pec. $190-150$

(one size $20 \times 20$

$\times 20$ in.)

(Note: Comments

in Phose II Summary

Report)

Spec. óm

Spec. 6L (55-gal)

Spec. $42 B(55-g a l)$

Spec. 6J (55-gol)

Spec. 17C (55-gal)

Spec. $17 \mathrm{H}(55-\mathrm{ga} !)$ 
TABLE 2-8

TRU LOW-LEVEL WASTE PACKACES IN USE ${ }^{\prime \prime}$

\section{Porkoge Description}

208-L steel drum, DOT $17 \mathrm{H}$, zinc dipped, polyethylene (PE) bog liner

208-L steel drum, DOT $17 \mathrm{H}$ interior and exterior pointed, $P E$ bog liner

208-L stainless steel drum, DOT I7H, PE bog liner

208-L steel drum, DOT 17C, interior and exterior painted, $\mathrm{PE}$ bog liner

208-L steel drum, DOT $17 \mathrm{C}$ interior and exterior pointed, 90 mil high density polyethylene (HDPE) liner; lead shielded (optional)

Corrugcied metal pipe, zinc dipped, $0.76 \mathrm{~m}$ diameter $\mathrm{x}$ $6 \mathrm{~m}$ lo:19

208-l_ steel drum, zinc dipped, 90 mil HDPE liner, insiae concrete culvert

Welded steel box, $3 \mathrm{~mm}$ thick, PE bag liner, random sizes, will fit inside supertiger

Random

Fiberglass reinforced polyester (FRP) plywood box, $1.2 \mathrm{~m} \times 1.2 \mathrm{~m} \times 2.1 \mathrm{~m}$, PE bag liner

FRP plywood box, random sizes, PE bog liner

Steel bin, $1.2 \mathrm{~m} \times 1.5 \mathrm{~m} \times 1.8 \mathrm{~m}$, 12-gouge, 166-L DOT 17H steel drums or l" thick plywood box placed inside

FRP plywood box, random, steel drums inside

Rondom

FRP plywood boxes, cold rolled steel boxes, inside concrete culvert 
$43 \mathrm{~m}^{3}\left(8-1500 \mathrm{ft}^{3}\right)$. Depending on the materiols being shipped, i.e., the types of radionuclides and their gross $\alpha$ tivities, tronsportation r 'gulations may require that these containers be shipped with either averpacks or inner liners for the purpase of providing additional mechanical integrity ond/or radiotion shielding. Tables 2-9 through 2-11 present the most recent WIPP containers for TRU wostes from DOE facilities.

The commercial sector is expected to follow the general leod of DOE on fulure waste containers. Due to the lack of data on previous TRU waste disposal practices from the commercial sector, it can only be posfulated that DOT 7A contoiners, primarily the $17 \mathrm{H}$ and $17 \mathrm{C}$ drums (both 208-liter and 1/4-liter), were utitized in conjunction with the DOT 7A plywood box $(1.2 \times 1.2 \times 2.1 \mathrm{~m})$.

The ACNS reprocessing plant has identilied the use of three mild steel drums: 114-liter, 208-liter and 303-liter, Further, a 208-liter stainless steel drum was identified as well as o cladding hulls contoiner (dato being sought).

It appeors oppropriote to assume that the AGNS TRLI waste containers and the DOT TA box should cover the containers expected to contain commercially generoted TRU woste in the future. 
TABLE 2-9

DEFENSE CONTACT-HANDLEO TRU WASTE (LRUM) ${ }^{\prime \prime}$

\author{
Type of contoiner \\ Liner (if used) \\ Weight of container \\ Surfoce-dose rote \\ Surface contarnination \\ Waste properties
}

D0T-17C 55-gallon (208-L) steel drum

0.09 -in,-thick $(0.23 \mathrm{~cm})$, rigidpolyethylene inner liners

$640 \mathrm{lb}(290 \mathrm{~kg})$

$\leq 200 \mathrm{mrem} / \mathrm{hr}$

Limits in 49 CFR 173.397

Combustible:

poper, cordboard boxes, wooden boxes, plastic bags, rubber scrap, rags, surgical gloves, clothing, etc.

Noncombustible:

residues or solutions from chemical processing, building rubble, metal, glossware, sludges, and acids

\begin{tabular}{|c|}
\hline $\begin{array}{l}\text { Rociioactive } \\
\text { Isotope }\end{array}$ \\
\hline Pu-238 \\
\hline$P_{u-239}$ \\
\hline$D_{U-240}$ \\
\hline Pu-24l (beto emitter) \\
\hline$A m-241$ \\
\hline
\end{tabular}

TOTAL

Totol fissile content

Totol Pu

\section{Expected Activity} (Ci/drum)

$4.1 \times 10^{-2}$

$4.8 \times 10^{-1}$

$1.2 \times 10^{-1}$

2.9

$7.8 \times 10^{-3}$

\section{5}

$7.8 y$

$8 \mathrm{~g}$ 
TABLE 2-10

DEFENSE CONTACT-HANDLED TRU WASTE (BOX) $)^{\prime \prime}$

Type of container

Weight of container

Surfoce-dose rote

Surfoce contomination

Woste properties
DOr.7A $4 \times 4 \times 7 \mathrm{ft}(1.2 \times 1.2 \times 2.1 \mathrm{~m})$ plywood box and fiberglass-reinforced polyester coated box

Moximum $10,000 \mathrm{lb}(4,500 \mathrm{~kg}) ;$ typical $3,000 \mathrm{lb} \cdot(1,360 \mathrm{~kg})$

$\leq 200 \mathrm{mrem} / \mathrm{hr}$

Limits in 49 CFR 173.397

Combustible:

poper, cordboard boxes, wooden boxes, plnśic bags, rubber scrap, rags, surgical gloves, clothing etc.

Noncombustible:

residues or solutions from chemicol processing, building rubble, metal, glosswore, sludges, and ocids

Equipment and materials too large for 55-gallon drums
Rodiooctive
Isotope

Pu-238

Pu-239

Pu-240

Pu-24l (beto emitter)

Am-241

TOTAL

Totol fissile content

Totol Pu
Expected

Activity

(Ci/box)

$6.5 \times 10^{-2}$

$7.5 \times 10^{-1}$

$1.8 \times 10^{-1}$

4.6

$1.2 \times 10^{-2}$

5.6

$12.2 \mathrm{~g}$

139 
TABLE 2-11

DEFENSE REMOTELY Y HANDLED TRU WASTE "

$\begin{array}{ll}\begin{array}{l}\text { Type of container } \\ \text { Weight of container }\end{array} & \begin{array}{l}\text { Steel canister } \\ (1,200-\mathrm{L} \text { internol volume })\end{array} \\ \text { Surface-dose rate } & 10,000 \mathrm{lb}(., 500 \mathrm{~kg}) \\ \text { Surface contaminotion } & \leq 100 \mathrm{rem} / \mathrm{hr} \\ \text { Waste properties } & \text { Limits in } 49 \mathrm{CFR} 173.397 \\ & \text { Primarily nuncombustible: } \\ & \begin{array}{l}\text { concrete, steel, process } \\ \text { sludges, etc. }\end{array}\end{array}$

Radiooctive
Isotope

Sr $-90 / Y-90$

Co-60

Ru-106/Rh-106

$\mathrm{Cs}-137 / \mathrm{Bo}-137 \mathrm{~m}$

Eu-152

Eu-154

Th-232

U-234

U-235

U-238

Pu-238

Pu-239

Pu-240

Pu-241

Am-241

Cm-244

TOTAL

Total fissile content

Fissile density

\section{Activity \\ Level \\ (Ci/conister)}

$4.2 \times 10^{2}$

2.6

3.7

2.1

$5.3 \times 10^{-1}$

2.1

$1.2 \times 10^{-3}$

$9.7 \times 10^{-6}$

$4.1 \times 10^{-4}$

$8.9 \times 10^{-3}$

$1.1 \times 10^{-1}$

1.3

$3.0 \times 10^{-1}$

7.8

$2.1 \times 10^{-2}$

5.3

$4.5 \times 10$

$211.8 \mathrm{~g}$

$0.177 \mathrm{~g} / 1$ 


\subsection{COMMERCIAL NUCLEAR NDUSTRY TRU WASTE CHARACTERISTICS $5,38,24$}

The commercial nuclear industry typically is understood to include all nuclear fuel cycle activities. For the purpose of this report other non-fuel cycle waste sources or potential sources will also be reviewed. Figure 2-1 shows the nuclear fuel cycle. If is reasonably well accepted that transuranic contaminated wastes are primarily generoted by the bock end of the fuel cycle. In a plutoniumrecycle fuel cycle, the sources of these transuranic wastes wilk include fuel enrichment facilities, the fuel fobricotion industry and the spent fuel reprocessing industry.

Transuranium nuclides are produced by a series of neutron captures with soine intervening beta and alpho decays. The parent of the bulk of the nuclides is the U-238 isatope present in the LWR fuel rods and in any tromp uranium present. Figure 3-I shows the chains by which the transuranic nuclides are produced. The shaded nuclides in the figure are those that are usually found in solid radioactive waste somples. If these nuclides are produced in the fuel rods, it is possible to calculate the nuclidic distribution of transuranic isotopes. Such colculations ore bosed on a known neutron flux and known capture cross sections and decay halflives and modes. The values from these colculations are quite sensitive to neutron flux and to time. Table 3.1 shows o toble of such nuclide distribution for a 1000 MWe plant operated for one year.

\subsection{FUEL FABRICATION INDUSTRY $70,38,5$}

The commerciol nuclear power industry is presently supported in the U.S. b; seven major uranium fuel fabricators processing low enriched uranium hexafluoride (UF 6 ) into finished fuel assemblies of uranium oxide pellets clad in zircaloy tubing. There ore six commercinlly operated fue fabrication facilities (see Table 3-2) having a capability of handling reasonably large quantities of plutonium. All of them are charocterized as being pilot scole; none are suitoble for supporting a large-scale commercial plutonium-recycle industry. Their total annuc! production copacity has been estimated to be 50-75 MT/yr. One 


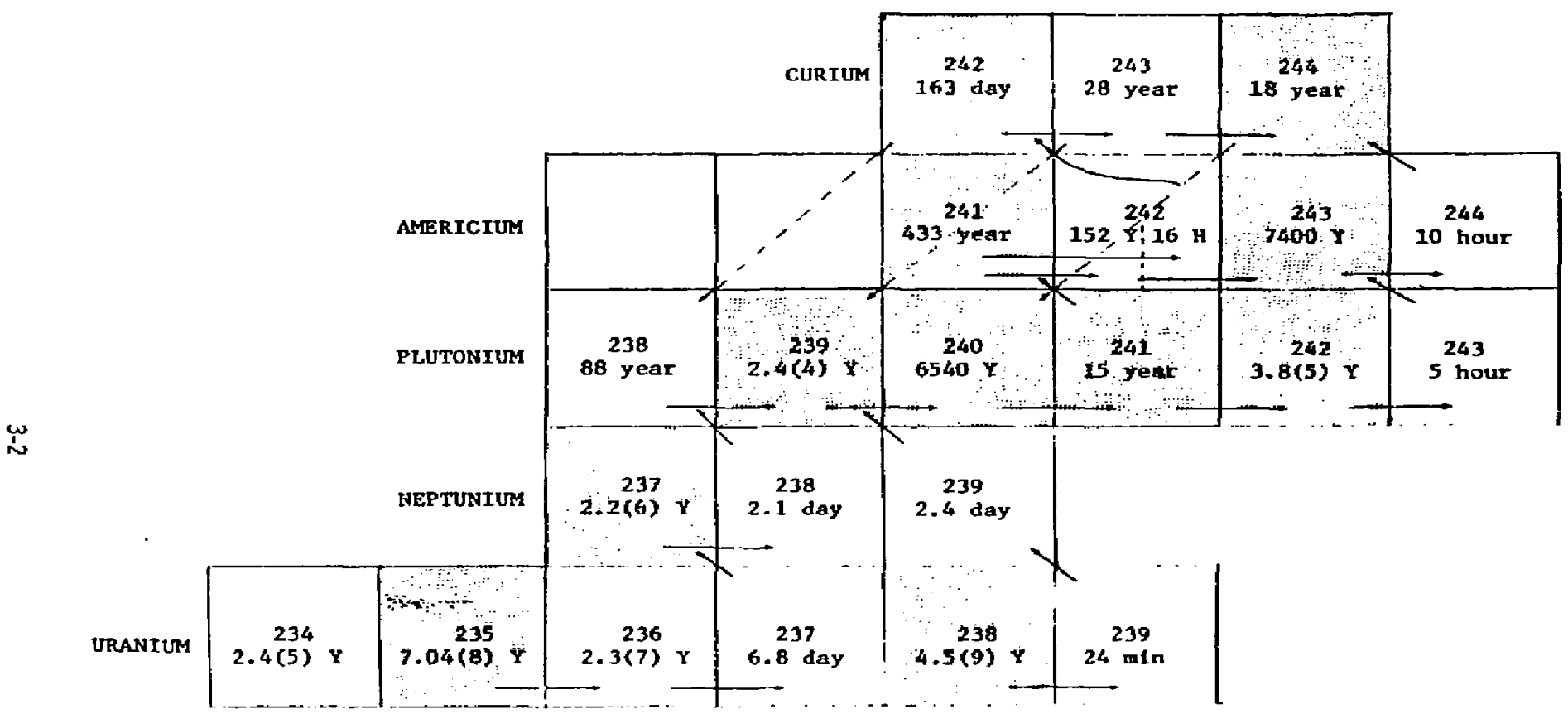


TABLE 3-1

CALCULATED YEARLY PRODUCTION FROM 1000 MWe PLANT (\% OF TOTAL TRANSURANIC ACTIVITY)

\begin{tabular}{lcc} 
Nuclide & Including Pu-21!! & Excluding Pu-241 \\
\cline { 2 - 2 } & 0.4 & 2.1 \\
Pu-238 & 2.9 & 15.7 \\
P.j-239 & 0.3 & 1.4 \\
Pu-240 & 0.4 & 2.1 \\
Pu-241 & 81.4 & - \\
Pu-242 & 0.001 & 0.006 \\
Am-241 & 0.13 & 0.71 \\
Am-242 & 0.003 & 0.018 \\
Am-243 & 0.01 & 0.074 \\
Cm-242 & 12.7 & 68.5 \\
Cm-243 & 0.003 & 0.014 \\
Cm-244 & 2.1 & 11.5
\end{tabular}


TABLE 3-2

EXISTING MIXED-OXIDE FABRICATION FACILITIES

\begin{tabular}{|c|c|c|c|}
\hline Compony & Location & $\begin{array}{c}\text { Pu Possession } \\
\text { Limit (kg) }\end{array}$ & $\begin{array}{c}\text { Estimated } \\
\text { Production } \\
\text { Capacity } \\
\text { (miT/yr) }\end{array}$ \\
\hline Exxon Nuclear & Richlond, Wosh. & 100 & 15 \\
\hline General Electric & Pleosanton, Calif. & 15 & 3 \\
\hline Kert-Mcūee & Crescent, Okla. & 360 & $5-10$ \\
\hline NUMEC & Apollo, $\mathrm{Po}$. & 2,000 & 20 \\
\hline Westinghouse & Cheswick, Po, & 120 & 10.15 \\
\hline Nuclear Fuel Services & Erwin, Tenn. & 100 & - \\
\hline
\end{tabular}


adeitional MOX fuel rod plant of commercial production capacity is in the phanr.ing stoge. Fuel fabrication data obtained from historical records of mixedoxide commercial fuel fobricators and current waste generation doto have been reviewed and cotegorized according to five waste categories: combustible liquids, combustible solids, mn-combistible liquids, non-combustible solids, and heterogeneous (partially combustible moterials, such as HEPA filters). ${ }^{70}$ The data will vary significantly due to the starting form of fuel moterial (i.e., PuO as supplied for the mechanical blending process versus a mixture of uranium and plutonium nitrate for the coprecipitation process).

The extrocted plutonium from the chemical reprocessing step of spent fuel ir combined with notural uranium of the mixed oxide fuel fabricotion plont to form mixed uranium dioxide-plutonium diaxide fuel pins for recycle to the LWR. This material will contain trace amounts of radioactive impurities ofter decomtaminotion of fuel reprocessing. In the conventional process, plutonium dioxide powder is blended with ceramic grade uranium dioxide powder, follaved by the pelletizing, sintering and mechanical steps employed in the uranium fuel fabrication steps. Residual plutonium is recycled into the main process through a scrop recovery cycle. The fuel assemblies themselves may be fabricated from the looded fuel rods at the uranium fuel fobricotion plant. The finished pellets are looded into zircaloy tubes and the completed fuel rods are assembled in fixed arroys. Residual uranium and plutonium are recycled into the main process through a scrop recovery cycle.

However, JF $_{6}$ product from chemical reprocessing will coiitoin small quantities of fission products and transuranium isntopes. Specifications have been published which indicate the maximum acceptable limits for radioactivity resulting from these impurities. These are: grass olpho due to transuranium isotopes 1,500 dis/min/(g of U); gross beta due to fission products and transuranium isotopes - 10 percent of the beto activity of aged 1: srmal uranium; and gross garnmia due to fission products and transuranium isotopes - 20 percent of the gamma activity of aged normal uronium. Such processed uranium may then be sent to the enriching plont. 5 


\subsubsection{WASTE GENERATION AND HANDLING PRACTICES ${ }^{5}$}

Most of the wastes from processing or fabrication operations and the associated analytical work are generated inside glove boxes. However, a significant amount of waste is generated outside the boxes from contamination contral measures. Usually, liquid wastes are segregated from sulid wastes which are bagged in plostic, In addition, plutonium-contaminated wostes are often sorted by enrichment level. In plants that can be termed production rother than development facilities, wastes are separated from those that are condidates for disposal by burial.

In general, solid wastes are the conglomeratas arising from the processing and contamination contral efforts on: cansist primarily of poper (wipes ariu cortons) and plasicc (bogs). The radiooctive constituent is often initially a fine powder. The degree of segregation of poper and plastic depends primarily or, the type and extent of scrop recovery. It is estimated that the solid waste stream is about half plastic and half poper, but numerous other constituents are dircarded into this stream including cloth, rubber (gloves), glasswore, unusable equipment and toals, metal cons, graphite, spent ion-exchange resin, asbestos paper fiber filters, and even small amounts of treated or solidified liquid (usurlly organics or oil). This solid waste stream is bagged in plastic and then placed in the plastic lined 208-liter drums. Lorger items ore crated for burial.

Each fuel fabricator has of least four types of wastes: solids from the main process line which are small enough to fit into 208-liter arums, larger sized solid waste such as failed equipment, slightiy contominated solids generoted in cleanup of smoll spills outside the main process line and laboratory liquid wastes. Mlost fabricotors also generote liquid wastes from plutonium processing, scrop recovery or other sources.

The probable method of handling scrap in an essentially dry fabrication plant includes on-site chemical purificotion or return of the scrap oxide to the reprocessing plant for dissolution, purification, and reconversion to the oxide. 
Waste generated during conversion of reprocessing plant plutonium nitrate solutions to plutonium oxide will be included with other reprocessing plant wastes.

\subsubsection{SOLIDS FROM MAIN PROCESS LINE 5}

Most fuel fabrication operations are performed in dry glove bo'ses. Solid waste includes wipes, neoprene gloves, small failed equipment and small air filters. Most of the waste from glove boxes results from cleonip operations. Major spills are usually recovered by using a point brush and dust pan. Some processors use vocuum cleaners for more complete removal of dry powders which occumulate in the glove iox. Occosional cleanup of the residuol powders, usuolly by wipes or cheesecloth, is necessory to provide proper contamination and exposure control. Thus, most of the solid waste from glove boxes is initially cellulose moterials. The waste is removed from the box by bogging in PVC and a second PVC bag is often added for additional safety as soon as the first bag is cut from the box. This introduces on apprecioble amount of plostic into the waste. Neoprene gloves have to be changed regularly and contribute additional plastic similar to the PVC. If sphincter contc ; ore used, they also contribute either cardboord or aluminum to the wastes. Some plastic boitles or cardboord containers are often used within glove boxes. Glassware is less common, but might be used by some fabricators.

Under special conditions cleanup might be accompanied by liquids for more exhaustive cleaning. Usuolly these are chemically relatively mild, innocuous liquids. Many processors use cheesecloth and nitric acid for cleaning stubborn residues of plutonium. Cloth or papers soaked with nitric acid are rinsed with woter before being discorded, and often they are neutralized with coustic substances. Since nitric acid solutions are used only in the final stages of cleaning, these moterials usually contain only small amounts of plutonium.

Other small items from the glove box are included in this type of waste (e.g., marking pens, tools, prefilters and small failed equipment). If the item is small enough to fit into a 208-liter drum, or can be reduced to this size easily, it is usually treated the same os other small waste items. 
Woste is usually not sorted into various types (e.g., cloth, paper, plastic, tools and equipment) unless one or more types may contain enough plutonium to male recovery economically attractive. If rernusty is contemplated, material is usually sorted into three classes: cellulose, plastis and other. Cellulosic material is incinerated or oxidized and the residue is leached to recover plutonium. Plostics moy be treated similarly to cellulosic materials, or may be leoched for plutonium recovery, Leaching of plastics is reported to be much more efficient if shredding is done beforehand. Plutonium may be recovered from other wastes by leaching. Most of the waste reprocessing is only in the pianning states or limited to batches of waste which have unusually large amounts of plutonium.

\subsubsection{LARCE FAILED EQUIPMENT ${ }^{5}$}

Some equipment items are not easily reducible in size. Such equipment is cleaned as much as practicable, enclosed in plastic for contamination control and placed in a shipping container. Since large equipment does not fail often, each is treated as a special cose ut present. Disposal containers are built to fit the particular needs for each shipment. Special pretreatment can also be used to minimize the potential for spread of contaminution.

Large air filters are considered and handled as large equipment, even though they are replaced routinaly. If they contain appreciable amounts of plutonium, some recover; may be performed. Filters are typically about the size of a $0.6 \mathrm{~m}$ on a side culte consisting of fire resistant filter medio in a wooden frame. Prefilters are often used on each individual glove box to reduce the amount of plutonium which can reach the lorge filters.

\subsubsection{SLIGHTLY CONTAMINATED SOLIDS ${ }^{5}$}

Small accurrences of contamination outside the glove baxes must be cleaned thoroughly. This generates a large volume of waste with very litt! plutonium confent. Most of the waste is cellulose and rubber gloves. Cloths or papers soaked with liquids are treated the same os those used in glove boxes. This type 
of waste could most easily be compacted since the plutonium content is very low and it is the least suitable for scrop recovery. Waste is usually collected in plastic bags (mostly, olyethylene) and deposited in 208-liter drums. All plutonium fabricators use extreme caution to maintain a very clean work area outside of the glove boxes so that normal materials used outside the boxes do not become contaminated.

\subsubsection{CHEMICAL PROCESSING LIQUIDS 5}

Chemical processing liquids for waste disposal originate primarily as aqueavs, often acidic, streams that include effluents such as process filtrotes, pickling liquids and decontaminotion liquids. Conventional water treatment steps convert the major radioactive components into a sludge which is then of ten solidified by incorporation into a second medium, e.g., cement.

\subsubsection{MISCELLANEOUS LIQUIDS}

In addition to processing liquids, small and poorly defined quantities of plutonium-containing organic solutions and vacuum pump oils are generated. The organic solutions include solvents as well as complex chemicals associaied with laboratory studies. Some solvents specifically identified are kerosene (used as a lubricant in metollography), trichloroethylene and carbon tetrachloride. In general, current methods of treating or fixing these liquids are the same as those described above for the processing liquids. The treated miscelloneous liquids are often disposed of along with solids from the main process line, since the incorporation or odsorption step is usuolly conducted in small vessels inside glove boxes.

\subsubsection{OTHER SOLIDS ${ }^{5}$}

A few types of solid waste do not fit $\sigma$, propriately in any of the above categories since they are not routinely generated, and they may contoin significant amounts of plutanium. One such waste is spent ion exchonge resins. Usually these are sulfonic acid types which are used in scrap recovery operations. Before disposal 
they ore woshed with woter or diluted coustic substances to remove nitric ocid. They moy be blerided with concrete or air dried and treoted as dry solid woste.

Costing compounds ore used in metollographic or ceramographic examination of fuels and components. Polishing results in finely divided organic materials mixed with olpha-emitters. The scole of operotions determines the advisotility of recovering the plutonium. Also, the mounted specimen of ter examinotion may be discorded if the plutonium coritent does not varrant recovery. Some of themounting moterial becomes woste by spilloge or deferioration before use. Although the volume is small, this type of waste introduces components not otherwise present in the waste.

Suality control processes often use special chemicals which are introduced ir: excess of the amount required. Virtually any chemical may be used for special analyses or for testing nev: onalytical procedures. Usually these are introduced as solutions and eventullly become laboratory liguid waste.

\subsubsection{WOY: FUEL FABFICATICI! WASTE QUAI!TITIE5 5.36.3E}

From the above discussion: it is understood that the wastes of concern in this study are the liquic and solids generated during MCX fuel fobricotion Thit liquids include: salt solutions, orgenic liquids and surfactont/detergent solutions. The solid wastes are comprised of wet porticulote solids. dry particulate solids and combustible and noncombustible solids. Table 3-3 presents the sources of the non-high-level fabrication wostes which are onticipoter to be TFI or potentially TRU-contaminated.

A typical woste distribution for a co-precipitation process. mixed-oxide fupl fobricotion plant is given in Table 3-4. The proportions anc indeed the totol volume. can vary considerably from plant to plant. For this report. about holf of the alpho wastes are generoted as room wastes. outside the process glove boxes. and may not have sufficient plutonium contamination to require searegation and treatment as TRU wastes. About holf of the process or glove box waste ar 


\section{SOURCES AND QUANTITIES OF NON-HICH LEVEL MOX FUEL FABRII ATION TRU-WASTES}

Woste Cotegory $\quad \begin{gathered}\text { Estimoted } \\ \text { Woste Volume } \\ \mathrm{m}^{3} / \mathrm{MTHM}^{(0)}\end{gathered} \quad$ Woste Description

1. Salt Solutions

0.08

Concentroted scrop recovery, decontamination, and off-gos scrub liquids.

2. Surfoctants/Detergent

0.01

Loundry wostes, personnel deSolutions contamination solutions.

3. Orgonic Liquids

0.0015

Pneumatic fluids, oils, laboratory solvents.

4. Wet Particulates

0.0003

Beod ion exchange resins used for liquid effluent treatment.

5. Dry Porticulates

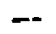

Floor sweepings, etc. Volume not identified.

6. Combustible Solids

Generol trash (cellulosics, plastics, rubber - uncompacted).

0.06 Ventilotion (HEPA) filters $(i$ 's to 60 w to combustible).

7. Noncombustible Solids General trash. $\mathrm{PuO}_{2}$ cans, etc.
(uncompacted) Foiled equipment, furnace brick.

TOTAL

1.05

(a) MTHM - Metric Tons Heavy Metal. Volumes ore bosed on annual throughput at a large $(-400 \mathrm{MTHM} / \mathrm{yr})$ mixed oxide fuel fabrication plant. Amounts are representative of typical facilities, but not all focilities will have the full spectrum of wastes. 
TABLE 3-4

TYPICAL WASTE DISTRIBUTION

IN A MOX FUEL PREPARATION-FABRICATION PLANT

(VOLUME PERCENT BASIS) $^{30}$

Woste Type

Percent

Process Area Woste

- $\quad$ including paper, plastics, rags, etc.

50

Glove Box Woste

- Liquid wastes

(precipitotion and scrop recovery) 25

- Rubber and plastic 15

- Paper and rogs 7

- HEPA filters 2

- Metc: and glass

* Based upon $0.85 \mathrm{~m}^{3} / \mathrm{kg}$ Pu processad (as generoted waste) 
liquids from precipitation, scrap recovery, and decontamination operations. The remaining waste is lorgely combustible materiol ond includes wipes, gloves, bogs and bagging moterial, and filters. Chlorinated plastics and pubbers constitute a significant fraction of the combustible waste.

HEPA (high efficiency porficulate air) filters also present a mojor disposal problem. Although constifuting only two to ten percent of the woste volume, they contain perhops ten to twenty percent of the plutonium lost in fuel fabrication operations. Although some are small enough $(0.2 \mathrm{~m}$ per side) to fit in conventional disposal drums, others are large enough $10.6 \mathrm{~m}$ square by $0.3 \mathrm{~m}$ deep) to require special packaging or dissection for disposal. Most HEPA filters use a glass fiber or glass fiber-asbestos filter medium framed in plywood, pressed Loard, or mefal. Commonly, HEPA filters also contoin aluminum or astesios spocers. The filter medium is sealed to the housing by meons of an organic or silicane resin. This cambination of materiols and geometries presents considerable difficulty in devising treatment methods for plutanium recovery and valume reduction for disposol.

\subsection{WASTE FROM THE SPENTT FUEL REPROCESSING INDUSTRY |3!}

Following a cycle of exposure in the LWR, the spent fuel can be chemically processed to recover the unburned uranium and plutonium and seporate the fission products for starnge or ultimate disposol. The generic spent fuel reprocessing plant is located on a relatjvely large site and uses the Purex process to separate fissile material from the fission products.

In the seporations focility, individual fuel assemblies are chopped into short lengths, lecched in hot, concentrated nitric acid to dissolve the oxide fuels, and ofter chernical adjustment, the dissolver solution is fed to a solvent extraction system. By proper odjustment of operating conditions, the fission products are removed from the uranium and plutonium, then the uranium and plutariun are separated from one another and further purified. The metallic residues fram the dissolution step, or hulls, are one of the solid wastes from reprocessing. Other solid wastes from this focility include used ventilation filters, trash from contaminated areos, solid process wastes, and some failed equipment. 
In the uranium conversion fecility, uranium nitrate is processed to the oxide, to the fluoride, and finally to the hexafluoride in less-shielded equipment. However, low levels of uranium (some plutonium) contamination will be present on trash, ventilation filters, and solid process wostes formed during cleanup of offgases released in the processing operations. These wostes constitute, for the most part, nontransuronic wastes.

In the plutonium conversion facility of the reprocessing complex, the plutonium nitrate is changed to an oxalate and then to an oxide. During all of this processing, in either shielded cells or glove boxes, little personnel contoct is made with the equipment or process streoms. Waste occumulates as spent ventilation filters, foiled equipment, or trash lat the crossover point from noncontaminated to contaminated areas). Mast of these wastes will be classitied os TRU wastes.

In the high-level solidification focilify, liquid wastes containing essentially all the non-volatile fission products are dried and heoted to a sufficiently high temperature to convert the fission product nitrates to oxides. The oxides are blended with other ingredients and heated to a higher temperoture to form a molten glass. After solidification and some radionctive decay, those wostes can be sent to a federal repository for final storage. Low-level wastes accumulate in support of entries to contaminated areas and from failed equipment which could not be decontaminated. Higher-level wastes accumulate from spent ventilation filters and failed equipment.

\subsubsection{TYPES OF WASTES ${ }^{|3|}$}

Solid wastes fram reprocessing plants can be classified functionally into the following general categories: cladding hulls, intermediate- and low-level waste, general trash, equipment and dry chemicals.

- Cladding Hulls - This category is simply the residual fuel element cladding and hardwore from the dismantling, shearing, and dissolving operafions. Although in many instances other equipment hardware is added with the hulls, the equipment hardware is included in the equipment cotegory for the purposes of this survey. 
- Intermediate- and Low-Level Wastes (ILW/LLW) - A liquid effluent is generated which is first highly concentrated and then ploced in tanks for storoge. The liquid is principally from washing of solvent, decontaminotion of equipment and chemical digestion (e.g., ion exchange disposal). Another solid which is added to [LW/LLW is metol fines from sheoring and sowing.

- General Trash - All solid moterial which leaves the plant for disposal is termed general trash if it is not specifically included in onother category. For example, off-gas ventilation filters are included as general trosh. Also, if plutonium scrop recovery operations are conducted, the waste is included as general trash.

- Equipment - Obsolete equipment, or foiled equipment which is removed from service, is incivided in the equipment cotegory.

- Dry Chemicals - Since some of the plant operations include uranium conversion to UF 6 , the salids originating from this operation ate identified as dry chemicals.

\subsubsection{SOURCES OF WASTE IN THE SPENT FUEL REPROCESSING INDUSTRY 5,38}

For the fuel reprocessing plant, waste identification is best clarified by discussing each source of waste which potentially contains plutonium or other TRU radionuclides.

\subsubsection{FUEL RECEIVIING ${ }^{5,38}$}

The water bosin for receipt and storoge of fuels contains o cleonup system which from time to time requires replacement of the ion exchange resin. The plutonium content is generally unknown but is considered TRU-contaminoted. Up $107 \mathrm{~m}^{3}$ of resin are expected to be disposed of eoch year from larger basins. Disposal concepts and practices vary. For purposes of this review, the waste from fuel receiving is included as generol trosh and wet porticulates. 


\subsubsection{HEAD END TREATMENT $T^{5}$}

The treotment for removal of iodine varies from aqueous scrubbing to silver reactors and silver zeolites. Replacement of the zeolites is anticipoted to produce an overall average of 0.002 cubic meter per metric ton of fuel processed. For disposal, the zeolites are placed in 208-liter drums, and will be defined as alpha contaminated or TRU contaminated depending upon actual concentration of TRU radio-isotope. However, the plutonium content in this general trash is expected to be small. HEPA filters on the dissolver off-gos are reploced periodicolly, except in those plants which use permanently installed filters (e.g., sand). The volume of filter replacement varies; the volume of used filters is somewhat independent of throughput. No measurements or estimates of the amount of plutonium on the filters are available. The quantity of filters is included as general trash.

Reactor scrap, cladding hulls and pieces of fuel hardwore ore produced from o chop leach head end in all plants and are included as o separate category. Reactor scrap consists of removable, nonfuel-bearing components, such as control rods, axial power-shaping rods, burnable poison rods, thimble plugs, flow channels, startup sources, and in-core instrument strings. The reactor operotor will be encouraged to remove these components at his site and ship them directly to disposal sites without involving the reprocessor in the handling operations. $|3|$ The hulls will include element en_-fittings, shrouds, spacers, nonremovable poison assemblies, possibly flow channels, and in-core instruments which did not dissolve in the nitric acid leach process step. Although there has been some stainless steel cladding and stainless steel parts, as well as zirconium, it is antici pated that about 95 percent by weight of all future cladding hulls and hardware will be zirconium until fast reactor fuels are reprocessed. As shown in Figure 2-2, the amount of plutonium in the hulls is nominally 0.1 percent of the fotal plutanium in the fuel processed. This is expected to be somewhat lower with longer fueis (because fewer pieces exist with only one end open). Thus, the plutonium content is generally estimated to be about 0.02 percent to 0.1 percent of throughput. The volume af the hulls and hardware ranges from 0.3 to 0.55 cubic meter per metric ton. 


\section{2 .2 .3}

Most of the moterial occumulated throughout a reprocessing plant is handled in the form it is collected. Some classification of the waste occurs becouse it is occumulated at a specific location in the plant or because of its high betogamma activity. Typically, this general trash is composed of electrical cords, lig'ts, wire cables, small equipment, glass, rags, poper and cotton wipes, clothing, floor sweepings, tope, rubbers, lead, filters, manipulator boots and sleeves and oll forms of plastic. Estimates of the amount of combustible materiol vary from 50 to 70 weight percent if the plastics ore considered noncombustible. In sume cases the noncombustible was estimated at 10 percent with up to onother 10 percent being moisture. The volume of generol trosh (including TRU-contaminated material) ranges from 1 to 9 cubic meters per metric ton of fuel processed. Where filters are routinely replaced in the plant, the volume of filters will overoge from 0.02 to 0.2 cubic meter of filters per metric ton. The general trost। will be generoted throughout the reprocessing complex with about 4.5 percent coming from the separations plant, 20 percent from facility ventilation filters and the remaining 35 percent divided between sources from uronium conversion facility, plutonium conversion facility and the high-level waste solidification facility. Tuble 3-5 presents a breakdown af the sources from the separations plant.

The following discussion presents waste quantities for o commercial 1,500 MTU facility. ${ }^{|3|}$

The analytical loboratories are expected to contribute only one 208-liter drum of waste per day. This low volume of waste is the result of features such as remote process sampling directly into the conalytical hot cell area, o pneumatic rabbit tube to corry primary dilutions of samples directly from the hot cells to the laboratory, and closed glove boxes for final sample preporation. 131

The change rooms, where personnel prepare for entry into contaminated areas ar make their final cleanup ofter leaving those areas, are expected to contribute two 208-liter drums of trash each day. 
TABLE 3-5

SOURCE OF GENERAL TRASH

FROM SEPARATIONS PLANT ${ }^{5}$

Source

Percent

of

Distribution

Analytical Laborutories

5

Change Rooms

10

Chemical Process Areas

10

Cold Chemical Mokeup Areo

15

Mechanical Process Area

15

Pipe and Instrument Golleries

15

Fuel Handling and Storage

$\underline{30}$

TOTAL

100 
The chemical process areas include trash which accumulates while servicing remote drive units on in-cell processing components, maintenance on in-line analyzers which circulate process streams past plutonium monitors, and trash generated from mointenance on numerous master-slave manipulators serving the analytical hot cells. Overall, two 208-liter drums per day of solid, rodioactive wastes should occumulate from those areas.

In the mechanical process areas, most of the general trash will accumulate from maintenance operations on moster-slove manipulators, powered manipulators, overheod cranes in remote service in support of fuel transfer from the pools, chopping of fuel, and monitoring and dumping of hulls. Trash will also be produced in support of maintenonce of the chopped fuel distribution system and the fuel shear. Semiannually, the roughing and HEPA filters installed on the ventilation exhaust from these cells are expected to be changed by withdrawing the filters into a lead-shielded cosk. Filter-handling operations will contribute some contaminated trash, since the area will hove to be protected with plostic sheeting in cose some leokage occurs during cask handling operations. About three 208-liter drums of trash pei doy will come from the mechanicol process areas.

Pipe and instrument galleries located above the cells and along one wall of the remotely-operated chemicol processing cells provide direct connections into incell processing vessels. Thus, maintenance on instrument systems will couse accumulation of contaminated trash. Also, the ventilation filter plenum, which removes radiooctive particulates from exhaust air leaving the extraction cells, represents a waste source in one of the gilleries. During maintenance work or changeout of filters in the galleries, wastes will accumulate primarily from paper and plastic protective coverings installed over the areas before work begins. The various gallery areas should generate three 208-liter drums of trosh per day.

The fuel handling and storoge area will receive several hundred roil and truck shipments of spent fuel and could make up to another 350 autbound shipments of reactor waste to private burial sites each year. This area is expected to 
contribute five 208-liter drums of trash per doy. This waste comes lorgely from areo cleanup, final hand-cleaning operations on casks, and throwaway protective clothing items.

The dato shown in Table 3-6 identify cambustible wastes and were obtained from actual purchase records at a commercial focility. The table shows that 34 percent by weight of the combustible solid wastes in this instance were plastic. 58 percent of these plasti: c, or 20 percent of the total combustible waste, were chlorinated. The principal chlorinated plastic identified was polyvinyl chloride. In another focility, these percentages might differ considerobly, since o numter of options would be ovoilable concerning which materials are used. For example, the matting used on floors might be either rubber or plastic, or the bagging materiol used in the facility could be polyethylene or polyvinyl chloride. Thus, it is clear that the waste generator can influence the characier of the combustible waste generated simply by the choice of purchased materials and supplies.

From Toble 3-6, it is seen that the lorgest single grouping of most common items is absorbent materials such as sponges, rags, and towels. Collectively, the largest source of waste is clothing.

\subsubsection{EQUIPMENT DISPOSAL}

Periodic failure of equipment requires the disposal of all sizes and shopes of anipiricuil. This equipment includes such items as process vessels (e.g., calciner), fittings, furnaces, failed cranes, manipulators, pumps, valves and their support equipment. Small pieces can be handled in the same manner as the cladding hulls. For example, pipe jumpers, volves, pumps, efc., can be sawed into small pieces and stored with the cladding hulls. Lorge pieces of equipment require special handling in plywood or concrete boxes, Each situation is considered special.

The omount of equipment disposal varies and, of course, peaks during a maintenance period and/or a process change. No equipment may be sent to 


\section{TABLE 3-6}

COMBUSTIBLE SOLID WASTES FROM REPROCESSINC OPERATIONS ${ }^{34}$

\begin{tabular}{|c|c|c|c|}
\hline $\begin{array}{c}\text { Major } \\
\text { Subcategories }\end{array}$ & $\begin{array}{l}\text { Weight Percent } \\
\text { of Totol } \\
\text { Combustible Solids }\end{array}$ & Most Common ltems & $\begin{array}{c}\text { Weight Percen } \\
\text { of Totol } \\
\text { Combustible } \\
\text { Solids }\end{array}$ \\
\hline
\end{tabular}

Plastics

(58\% of these are chlorinated

Rubbers

Cellulosics
34

Matting, sheeting films

Bogs

Drum liners

Buckets, lobwore, containers

Gloves

2.1

22

Motting

Boots, gloves

Hose

12

7

44

Sponges, rags, towels

25

Coveralls, caps, other clothing

8

Boxes

9

Other

100 
burial for one to two years, but a considerable amount another year. The size moy range from 2 to 4 square meters and up to $12 \mathrm{~m}$ long. In terms of equipment volume, about 0.03 to $0.3 \mathrm{~m}^{3}$ per metric ton is expected.

The amount of plutoniuri contained on or in a piece of equipment is nor measured directly. Analysis of decontominating solutions indicates a low level of contamination. From typical surface dose readings, not more than about a gram of plutonium is expected to be on o rather lorge piece of equipment if plutonium is not held up in sludges or cokes.

\subsubsection{DRY CHEMICALS ${ }^{|3|}$}

If the conversion of the uronium to $U_{F}$ occurs at the reprocessing facility dry chemicols require disposol.

Process wastes originate primarily from the lacility to convert uranyl nitrate to hexafluoride and cons. it af: (1) fluorinator bed materials, which have to be replaced periodically after the bed materials have accumulated sufficient fission products during conversion of $U_{4}$ to $U_{6}$ to begin to influence allowable working times neor the equipment; (2) fines from carryover of the fluorinator bed; (3) a diuranate precipitate which accumulates from coustic scrubbing of HF and fluorine from the off-gas stream dawnstream of the UF ${ }_{6}$ product collection equipment; and (4) solids from coustic scrubbing of off-gases from intermediate processing steps.

In one instance this waste is about 85 percent $\mathrm{AlF}_{3}, 10$ percent $\mathrm{Al}_{2} \mathrm{O}_{3}$, and five (5) percent NaF and MgF $2^{\text {* }}$ The total volume is expected to be about $0.3 \mathrm{~m}^{3} / \mathrm{MT}$. In another approach the volume is ex sected to be about $0.1 \mathrm{~m}^{3} / M T$ and be principally $\mathrm{Co}(\mathrm{OH})_{2}, \mathrm{CoF}_{2}$ and $\mathrm{Al}_{2} \mathrm{O}_{3}$. The plutonium content is quite small since the partitioning during solvent extraction is expected to be good. Less than 0.1 percent of the plutonium throughput is lost to the uranium and eventually to dry chemical waste. 
The quantity of woste produced in the spent fuel reprocessing industry can best be reported by using the classifications of waste type discussed previously. The omouni of plutonium in each type of waste shown in Table 3-7 is shown as a function of plutonium throughput in Table 3-8. The values given $f(x)$ the proboble overoge are for the situation where the reprocessing plants are operating at near copocity levels.

The numbers in Table 3-7 represent actual waste volume as a function of fuel reprocessing rate. Additional space will be required for storage due to the irregular shapes of packages and for shielding. The volume of general trash is somewhat independent of throughput and is estimated to be $2,800 \mathrm{~m}^{3}$ per yeor per plont. Similarly, the volume of waste occupied by failed equipment is estimated to be $150 \mathrm{~m}^{3}$ per year per plant. Table 3.9 presents o breckdown of the wastes bosed upon combustibility. Table 3.10 presents a distribution of repracessing waste by container configuration.

\subsubsection{ACTINIUE CONTENT}

Reliable informotion on the amount of plutonium in the solid waste is locking becouse, in general, meosurements are not made to verify the quantities. Little is known about the composition of other isotopes in the woste. Only assumptions can be made, bosed on the fission spectro and the source of waste in the process. For example, neptunium is expected to average obout $1 / 20$ of the plutonium content. It has been stated that approximately 60 percent of all waste will be considered ITRU (presently greater than $10 \mathrm{nCi} / \mathrm{g}$ ). Table 3-11 presents some assumed charcicteristics at the presently ciosed NFS facility at West Valley, New York. These values compare fovorably with the information provided above.

The relative proportion of each type of waste is shown in Table 3-12 for plutonium content, and for radioactivity levels in Tables 3-13 and 3-14. The distribution of plutonium is expected to remain fairly constont through the yeors, 
TABLE 3.7

ESTIMATED VOLUMES OF SOLID TRU-WASTE 5

Cubic Meter per Metric Ton ${ }^{(a)}$

\begin{tabular}{lcc}
\multicolumn{1}{r}{ Woste Type } & Range & Probable Average \\
Cladding Hulls & 0.3 to 0.55 & 0.4 \\
ILW/LLW & 0.06 to 0.4 & 0.2 \\
General Trosh & 0.03 to 10 & (b) \\
Equipment & 0.03 to 0.3 & (c) \\
Dry Chemicals & 0.1 to 0.3 & 0.15
\end{tabular}

(a) Volume of actual waste. Pockaging, shielding and the irregular shape of packages may increase the space required for storoge by o foctor of up to 3.

(b) Volume of general trosh is independent of processing rote. Assumed to be 2,800 cubic meters per year per plant.

(c) Volume of equipment waste category is independent of processing rate. Assumed to be 150 cubic meters per year per plant. 
TABLE 3-8

PLUTONIUM IN SOLID WASTE 5

Pu in Solid Woste
Percent in Pu Throughput

Waste Type

Range

Proboble Average

Cladding Hulls

0.02 to 0.1

0.07

ILW/LLW

0.01 to 0.2

0.1

General Trash

0.001 to 0.3

0.05

Equipment

$-$

$0.0002^{(0)}$

Dry Chemicols

0.01 to 0.1

0.01

Totol

0.04 to 0.7

0.23

(a) Surfaces assumed to be decontaminated thoroughly, with no residual sludge. About one gram of $P_{u}$ expected for each large piece of equipment. 


\section{TABLE 3-9}

SORT OF WASTE BASED UPON COMBUSTIBILITY

Percent of

Total Woste

\section{Combustible}

General Trash

40

Noncombustible

Genercl Trash 10

Dry Chemicals $\quad 18$

Cladding Hulls 20

ILW/LLW 10

Equipment 2 
TABLE 3-10

\section{DISTRIBUTION OF WASTE \\ VOLUME BY CONTAINER CONFIGURATION}

\begin{tabular}{lc} 
Woste Container & $\begin{array}{c}\text { Percent } \\
\text { of Total } \\
\text { Woste Volume }\end{array}$ \\
\hline $\begin{array}{l}\text { Foiled Equipment } \\
\text { (special configuration) }\end{array}$ & 2 \\
Reactor Scrop Cons & 4 \\
Drums, 303-liter & 9 \\
Hulls Contoiners & 20 \\
Drums, 208-liter & 64
\end{tabular}


TALBLE 3-11

RADIOACTIVE WASTES GENF.RATED ANNUALLY AT NHS OLSIGN IRATE (MSO IUNNES/YEAiX)

\begin{tabular}{|c|c|c|c|c|c|c|c|c|}
\hline & & \multirow[b]{2}{*}{$\begin{array}{c}\text { High Level } \\
\text { Waste }\end{array}$} & \multicolumn{5}{|c|}{ Intergmedinte Level Waste } & \multirow[b]{2}{*}{$\begin{array}{c}\text { HEPA } \\
\text { Filters }\end{array}$} \\
\hline & & & $\begin{array}{l}\text { Lenched } \\
\text { rfulls }\end{array}$ & Solts & Sturry & Resin & Equipment & \\
\hline & $\begin{array}{l}\text { Original } \\
\text { quantity }\left(\mathrm{m}^{3}\right)\end{array}$ & 40 & 260 & 135 & 46 & 21 & 300 & 57 \\
\hline & $\begin{array}{l}\text { Percent } \\
\text { of total }\end{array}$ & 1.3 & B.3 & 4.3 & 1.5 & 0.6 & 9.3 & 1.8 \\
\hline & $\begin{array}{l}\text { Physicol } \\
\text { form }\end{array}$ & Solid & Solid & Slurry & Slurty & Selid & Solid & Solid \\
\hline & Chemical form & $\begin{array}{l}\text { Colcine } \\
\text { oxide of } \\
\text { MPF ond } \\
\text { added } \\
\text { inerts }\end{array}$ & $\begin{array}{l}\text { Zr ollor } \\
\text { or stain- } \\
\text { less steel }\end{array}$ & $\begin{array}{l}\text { Sodium } \\
\text { nitrate } \\
40 \% \text { solu- } \\
\text { tion } \\
\text { merecuric } \\
\text { iodale }\end{array}$ & $\begin{array}{l}\text { Filler } \\
\text { oid }\end{array}$ & $\begin{array}{l}\text { Orgonic } \\
\text { ond min- } \\
\text { eral resins }\end{array}$ & Metal & $\begin{array}{l}\text { General } \\
\text { dust on } \\
\text { glass filter }\end{array}$ \\
\hline \multirow[t]{4}{*}{ 心 } & $\begin{array}{l}\text { Rodio- } \\
\text { octivity } \\
\text { (m/final } \\
\text { volume) }\end{array}$ & $\begin{array}{l}99.95 \% \text { of } \\
\text { octivity } \\
\text { in fuel. } \\
\sim 3.5 \times 10^{6} \mathrm{Ci} \\
\text { of } \mathrm{MFP} / \mathrm{m}^{3}\end{array}$ & $\begin{array}{l}0.05 \% \text { of } \\
\text { octivity } \\
\text { in fuel. } \\
17,500 \mathrm{ci} \\
\text { co-60/m }\end{array}$ & $\begin{array}{l}20-40 \mathrm{Ci} \\
\text { of } \mathrm{MFP} \text { - } \\
0.01 \mathrm{Ci} \\
1-129 \\
53.539 \\
\mathrm{Pu} / \mathrm{m}^{3}\end{array}$ & $\begin{array}{l}35 \mathrm{~s} 350 \mathrm{Ci} / \\
\mathrm{mFP} . \\
<10 \mathrm{nCi} \\
\mathrm{Pu} / 9 .\end{array}$ & $\begin{array}{l}35 \mathrm{~g} 350 \mathrm{Ci} / \\
\mathrm{m} M F \mathrm{P} \\
<10 \mathrm{nCi} \\
\mathrm{Pu} / \mathrm{g} .\end{array}$ & $\begin{array}{l}\text { 1/,000 } \\
\text { mr/hr } \\
<10 \text { nci } \\
\text { Pu/g- }\end{array}$ & 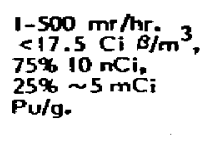 \\
\hline & Process & Colcine & -- & Dry & Dry & Concrete & $\begin{array}{l}\text { Decon- } \\
\text { concrete os } \\
\text { necessory }\end{array}$ & Compoction \\
\hline & $\begin{array}{l}\text { Shipping } \\
\text { conlainer }\end{array}$ & $\begin{array}{l}0.5 m \times 5 m \\
\text { canisters }\end{array}$ & $\begin{array}{l}\text { Steel } \\
\text { conisters }\end{array}$ & $\begin{array}{l}\text { Steel } \\
\text { canisters }\end{array}$ & $\begin{array}{l}208-1 \\
\text { deums }\end{array}$ & $\begin{array}{l}208-1 \\
\text { drums }\end{array}$ & $\begin{array}{l}\text { Spectiol } \\
\text { confainer } \\
\text { as required }\end{array}$ & $\begin{array}{l}\text { Sperial con- } \\
\text { tainer or } \\
\text { drum }\end{array}$ \\
\hline & $\begin{array}{l}\text { Finol } \\
\text { volumes }\left(\mathrm{m}^{3}\right)\end{array}$ & 80 & 260 & 122 & $\cdots$ & 42 & 440 & 14 \\
\hline & $\begin{array}{l}\text { Percent of } \\
\text { totol }\end{array}$ & 3.9 & 12.8 & 6.0 & 2.0 & 2.0 & 21.6 & 0.7 \\
\hline & MFP $+\operatorname{mixad} f i$ & ion iroducts & & & & & & \\
\hline
\end{tabular}


TALE 3-11

(CONT.)

\begin{tabular}{|c|c|c|c|c|c|c|}
\hline \multirow[b]{3}{*}{$\begin{array}{l}\text { Original } \\
\text { quantity }\left(\mathrm{n}^{3}\right)\end{array}$} & \multirow[b]{2}{*}{ Sotvent } & \multirow[b]{2}{*}{$\begin{array}{l}\text { Alpho Waste } \\
\text { Cambustible }\end{array}$} & \multicolumn{3}{|c|}{ Low Specific Activity Waste } & \multirow[b]{2}{*}{$\begin{array}{l}\text { Tolol } \\
\text { volume }\end{array}$} \\
\hline & & & Cambustible & Slurry & Snits & \\
\hline & 6 & 480 & 1,000 & 660 & 160 & 3.450 \\
\hline $\begin{array}{l}\text { Percent } \\
\text { of total }\end{array}$ & 0.2 & 15.3 & 31.5 & 24.0 & 4.9 & \\
\hline Physical form & Liquid & Solid & Solid & Slurry & Slurry & \\
\hline Chemical form & $\begin{array}{l}\text { Diluent } \\
\text { TBP }\end{array}$ & $\begin{array}{l}\text { Poper, } \\
\text { clath, rut- } \\
\text { ber, plostic, } \\
\text { miscelfaneous }\end{array}$ & Some & $\begin{array}{l}\text { Water terat- } \\
\text { mest, sludge, } \\
\mathrm{CoF}_{2}\end{array}$ & $\begin{array}{l}\text { Sodium } \\
\text { nitrate } \\
40 \% \text { solution }\end{array}$ & \\
\hline $\begin{array}{l}\text { Radio- } \\
\text { octivity } \\
\text { (m Iminal } \\
\text { volume) }\end{array}$ & $\begin{array}{l}>3.535 \mathrm{Ci} \\
\text { m } \mathrm{MFP} \\
=50 \mathrm{FCi} \\
\mathrm{Pu} / \mathrm{gCi}\end{array}$ & $\begin{array}{l}\sim 500 \mathrm{mr} / \mathrm{hr} \\
\sim 1069 \mathrm{Pu} / \mathrm{m}^{3}\end{array}$ & $\begin{array}{l}<200 \mathrm{mr} / \mathrm{hr} . \\
<10 \mathrm{nC}^{-} \\
\mathrm{Pu} / \mathrm{g} .\end{array}$ & $\begin{array}{l}<200 \mathrm{mr} / \mathrm{hr} \\
<10 \mathrm{mCi} \text { Pu/a. }\end{array}$ & $\begin{array}{l}<200 \mathrm{mr} / \mathrm{liter} \\
<10 \mathrm{nCi} \text { Pu/q. }\end{array}$ & \\
\hline Process & $\begin{array}{l}\text { Burn or } \\
\text { distill }\end{array}$ & Compoction & $\begin{array}{l}\text { Compoction } \\
\text { of imeinern- } \\
\text { tion }\end{array}$ & $\cdots$ & Dry or obsorb & \\
\hline $\begin{array}{l}\text { Shipping } \\
\text { container }\end{array}$ & $\begin{array}{l}\text { Mix with } \\
\text { ILW waste }\end{array}$ & $\begin{array}{l}208-1 \\
\text { drums }\end{array}$ & $\begin{array}{l}208-1 \\
\text { drums }\end{array}$ & $\begin{array}{l}208-1 \\
\text { drums }\end{array}$ & $\begin{array}{l}208-1 \\
\text { drums }\end{array}$ & \\
\hline $\begin{array}{l}\text { Final } \\
\text { volumes }\left(\mathrm{m}^{3}\right)\end{array}$ & 0.3 & 100 & 200 & 585 & 140 & 2.030 \\
\hline $\begin{array}{c}\text { srcent of } \\
\text { total }\end{array}$ & 0.01 & 5.2 & 9.8 & 28.9 & 7.0 & \\
\hline
\end{tabular}

MFP - mixed fission products 


\title{
TABLE 3-12
}

\section{PERCENTAGE DISTRIBUTION OF PLUTONIUM IN SOLID WASTE}

\author{
Percent of Total Pu \\ In All Wostes
}

Cladding Hulls

32

ILL/LLW'

42

Generol Trash

21

Foiled Equipment

1

Dry Chemicals

4

Total

100 
TABLE 3-13

RADIOACTIVITY LEVELS FOR TRU SOLID WASTES ${ }^{|3|}$

Woste Cotegory

General Trosh

Dry Chemical

Cladding Hulls

ILW/LLW

Equipment
Percent

4.3

25.0

57.0

8.6

4.4

0.7

100

5

65

30

100

100

\section{Activity Level $\left(\mathrm{Ci} / \mathrm{m}^{3}\right)$}

$3.5 \times 10^{-3}-10^{-2}$

$10^{-2}-2.5 \times 10^{-2}$

$2.5 \times 10^{-2}-2.5 \times 10^{-1}$

$2.5 \times 10^{-1}-4 \times 10^{-1}$

$4 \times 10^{-1}-7$

$7-36$

$3.5 \times 10^{-3}-3.5 \times 10^{-1}$

$10 \cdot 10^{3}$

$7 \times 10^{3}-7 \times 10^{4}$

$9 \times 10^{-3} \cdot 1.5 \times 10^{5}$

$3.5 \times 10^{-3}-3.5 \times 10^{-1}$

$3.5-3.5 \times 10^{3}$ 
TALLF. 3-14

EXPECTED VOLUMES AND HETA-GAMMA ACTIVITY LEVELS

OF TRANSURANIC WASTES FROM COMML RZCIAL

FUEL PEFPROCLSSING PLANTS(a) 35, 31

Waste Category

Combustible Solid

Combustible Liquid

Noncombustible Solid

Hulls \& Hardware

Equipment

Sorbents \& Resins

Trash

Fluorination Solids

ILW

HEPA Filters
Expected
Betg-Gommo Activity(b)

Expected Volume $\left(\mathrm{m}^{3} / \mathrm{MTU}\right)$

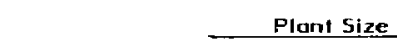

$$
\text { ronge }
$$

$500 \mathrm{MTU} / \mathrm{Yr}$

$1,500 \mathrm{MTU} / \mathrm{y}$

$<200$

mFihr $\quad$ mk/hr

$0.2-2.6$

$0.0 \mathrm{i}-0.1$

2.6

0.03

1.5

0.03

$0.4-0.6$

0 i -0.4

$0.01-0.1$

$0.01-0.7$

$0.1-0.3$

0.5

0.4

0.5

0.2

0.03

0.4

0.3

0.0

0.4

0.3

0.1

0.5

$0.08^{(c)}$

$0.08^{(c)}$

$0.06-0.3$

1-6

d. As generoted uncompacted volume as contained within drums

b. Expressed as percent of total valume in category

c. Assumes a central filter, gloss bed or sand 
with about 75 percent of the plutonium being associoted with the cladding hulls and the ILL/LLW categories. Tobles 3-15 and 3-16 present the curie content of the ciodding wastes.

Table 3-17 lists the composition of zircaloy-2, used for cladding fuel for boiling water reactors (BWR) and zircaloy-4, used to clod fuels for pressurized water reactors (PWR). Inconel components (e.g., grid plates for fuel tube spacing) which are also present in LWR fuels will olso become part of the cladding waste; nominal composition of Series 600 and $7 / 8$ inconels is given in Table 3-18. Besides zircaloy and inconel, the hull woste stream contains undissolved fuel parficles, fuel- $\mathrm{ZrO}_{2}$ corrosion product layer interaction products, and irradiated uranium and thorium impurities in the original metal. The impurity content of zircoloy alloys is shown in Toble 3-19. From 30 to 60 percent of the tritium formed during reactor irradiation of $\mathrm{UO}_{2}$ fuel is estimated to report to the zircaloy cladding. 49

The top and bottom ends of typical LWR fuel elements hove a heovy metal (stainless steel or zircaloy) nozzle attached which may be cut off and handled separately, at the discretion of the reprocessors, or be mixed with the leached hulls. If the latter is the case, it is estimated that, based on typical current fuel designs, the cladding waste would contain 29 and 21 percent stainless steel, respectively, for PWR and BWR fuels. 49

Prediction of woste production becomes tenuous due to the numerous uncertainties involved in future nuclear capacity as well as waste and residual management proctices. For exomple, the size of a plant, the extent of residual recovery, changes in regulations, the cost of waste disposal, and the value of plutonium are important and interrelated foctors in determ: ing the fraction of plutonium throughput which will be lost as waste. A recent analysis of the TRUcontaminated waste sources and quantities, presented in Table 3-20, generally supports earlier evaluations discussed above.

The fraction of plutonium lost during processing is expected to decrease as the throughput increases. This trend assumes that the fractional loss will decrease 


\section{TABLE 3.15}

CURIES OF TRU RADIOISOTOPES IN THE CLADDING WASTE FROM ONE METRIC TON OF URANIUM-ENRICHED FUEL

\begin{tabular}{|c|c|c|}
\hline \multicolumn{3}{|c|}{$\underline{P W R}^{(0)}$} \\
\hline & DISCHARGE & 10 Years \\
\hline $\begin{array}{l}\mathrm{Np}-239 \\
\mathrm{Pu}-238 \\
\mathrm{Pu}-239 \\
\mathrm{Pu}-240 \\
\mathrm{Pu}-241 \\
\mathrm{Am}-241 \\
\mathrm{Am}-242 \mathrm{M} \\
\mathrm{Am}-242 \\
\mathrm{Am}-243 \\
\mathrm{Cm}-242 \\
\mathrm{Cm}-243 \\
\mathrm{Cm}-244\end{array}$ & $\begin{array}{l}8.67 \mathrm{E}-03 \\
2.50 \mathrm{E}-01 \\
1.62 \mathrm{E}-01 \\
2.41 \mathrm{E}-01 \\
6.18 \mathrm{E}-01 \\
1.19 \mathrm{E}-01 \\
3.62 \mathrm{E}-03 \\
3.62 \mathrm{E}-03 \\
8.67 \mathrm{E}-03 \\
6.84 \mathrm{E}-00 \\
1.46 \mathrm{E}-03 \\
9.86 \mathrm{E}-01\end{array}$ & $\begin{array}{l}8.66 \mathrm{E}-03 \\
2.63 \mathrm{E}-01 \\
1.62 \mathrm{E}-01 \\
2.42 \mathrm{E}-01 \\
3.85 \mathrm{E}-01 \\
8.99 \mathrm{E}-01 \\
3.46 \mathrm{E}-03 \\
3.46 \mathrm{E}-03 \\
8.66 \mathrm{E}=03 \\
2.84 \mathrm{E}-03 \\
1.18 \mathrm{E}=03 \\
6.73 \mathrm{E}-01\end{array}$ \\
\hline \multirow[t]{3}{*}{ Totol } & $7.05 \mathrm{EOI}$ & 4.07EOI \\
\hline & BWR & \\
\hline & DISCHARGE & 10 Yeors \\
\hline $\begin{array}{l}\text { Np-239 } \\
\text { Pu-238 } \\
\text { Pu-239 } \\
\text { Pu-240 } \\
\text { Pu-241 } \\
\text { Am-241 } \\
\text { Am-242M } \\
\text { Am-242 } \\
\text { Am-243 } \\
\text { Cm-242 } \\
\text { Cm-244 }\end{array}$ & $\begin{array}{l}6.81 \mathrm{E}-03 \\
1.00 \mathrm{E}-00 \\
1.52 \mathrm{E}-01 \\
2.33 \mathrm{E}-01 \\
5.36 \mathrm{E}-01 \\
1.30 \mathrm{E}-01 \\
5.95 \mathrm{E}-03 \\
5.95 \mathrm{E}-03 \\
6.81 \mathrm{E}-03 \\
5.08 \mathrm{E}-00 \\
7.54 \mathrm{E}-01\end{array}$ & $\begin{array}{l}6.81 \mathrm{E}-03 \\
9.49 \mathrm{E}-01 \\
1.52 \mathrm{E}-01 \\
7.34 \mathrm{E}-01 \\
3.34 \mathrm{E}-01 \\
8.08 \mathrm{E}-01 \\
5.65 \mathrm{E}-03 \\
5.6 \mathrm{BE}-03 \\
6.81 \mathrm{E}-03 \\
4.66 \mathrm{E}-03 \\
5.14 \mathrm{E}-01\end{array}$ \\
\hline Total & $6.1|E O|$ & $3.6 \mathrm{IEOI}$ \\
\hline
\end{tabular}

(a) $8.67 \mathrm{E}-03 \mathrm{Ci}$ is equivalent to $8.67 \times 10^{-3} \mathrm{Ci}$ 
TABLE 3-16

CURIES OF TRU RADIOISOTOPES IN THE CLADDING WASTE FROM ONE METRIC TON OF PLUTONIUM-ENRICHED FUEL

\begin{tabular}{|c|c|c|c|}
\hline & & & \\
\hline & CHARGE & DISCHARGE & 10 Years \\
\hline $\begin{array}{l}\mathrm{Np}-239 \\
\mathrm{Pu}-238 \\
\mathrm{Pu}-239 \\
\mathrm{Pu}-240 \\
\mathrm{Pu}-241 \\
\mathrm{Pu}-242 \\
\mathrm{Am}-241 \\
\text { Am-242M } \\
\mathrm{Am}-242 \\
\mathrm{Am}-243 \\
\mathrm{Cm}-242 \\
\mathrm{Cm}-243 \\
\mathrm{Cm}-244 \\
\mathrm{Cm}-245 \\
\mathrm{Cm}-246\end{array}$ & $\begin{array}{c}0.0 \\
1.7 \mid \mathrm{E} 04 \\
1.37 \mathrm{E} 03 \\
2.55 \mathrm{E} 03 \\
6.76 \mathrm{E} 05 \\
1.48 \mathrm{E} 01 \\
0.0 \\
0.0 \\
0.0 \\
0.0 \\
0.0 \\
0.0 \\
0.0 \\
0.0 \\
0.0\end{array}$ & $\begin{array}{l}1.36 \mathrm{E}-01 \\
8.91 \mathrm{E} 00 \\
3.37 \mathrm{E}-01 \\
1.00 \mathrm{E} 00 \\
2.98 \mathrm{E} 02 \\
9.29 \mathrm{E}-03 \\
1.00 \mathrm{E} 00 \\
1.84 \mathrm{E}-01 \\
1.84 \mathrm{E}-01 \\
1.36 \mathrm{E}-01 \\
8.48 \mathrm{E}-01 \\
1.35 \mathrm{E}-02 \\
2.72 \mathrm{E} 01 \\
7.82 \mathrm{E}-03 \\
1.50 \mathrm{E}-03\end{array}$ & $\begin{array}{l}1.36 \mathrm{E}-01 \\
8.64 \mathrm{E}=00 \\
3.37 \mathrm{E}-01 \\
1.03 \mathrm{E} 00 \\
1.86 \mathrm{E}-02 \\
9.30 \mathrm{E}-03 \\
4.76 \mathrm{E}-00 \\
1.76 \mathrm{E}-01 \\
1.76 \mathrm{E}-01 \\
1.36 \mathrm{E}-01 \\
1.4 \mathrm{E}-01 \\
1.0 \mathrm{E}-01 \\
1.85 \mathrm{E}-02 \\
7.81 \mathrm{E}-03 \\
1.50 \mathrm{E}-03\end{array}$ \\
\hline Totol & $6.97 \mathrm{E} 05$ & 4.22E 02 & $2.20 \mathrm{E} 02$ \\
\hline & & & \\
\hline & CHARCE & DISCHARCE & 10 Years \\
\hline $\begin{array}{l}\text { Np-239 } \\
P ! J-238 \\
P u-239 \\
P u-240 \\
P u-241 \\
\text { Pu-242 } \\
\text { Am-241 } \\
\text { Am-242M } \\
\text { Am-242 } \\
\text { Am-243 } \\
\mathrm{Cm}-242 \\
\mathrm{Cm}-243 \\
\mathrm{Cm}-244 \\
\mathrm{Cm}-245 \\
\mathrm{Cm}-246\end{array}$ & $\begin{array}{l}0.0 \\
1.75 E 04 \\
1.17 E 03 \\
2.37 E 03 \\
5.30 E 05 \\
1.23 E 01 \\
0.0 \\
0.0 \\
0.0 \\
0.0 \\
0.0 \\
0.0 \\
0.0 \\
0.0 \\
0.0\end{array}$ & $\begin{array}{l}1.09 E-01 \\
9.47 \mathrm{E} 00 \\
2.92 \mathrm{E}-01 \\
9.44 \mathrm{E}-01 \\
2.49 \mathrm{E} 02 \\
7.49 \mathrm{E}-03 \\
1.12 \mathrm{E} 00 \\
1.16 \mathrm{E}-01 \\
1.16 \mathrm{E}-01 \\
1.09 \mathrm{E}-01 \\
5.79 \mathrm{E}-01 \\
8.72 \mathrm{E}-03 \\
1.96 \mathrm{E}-01 \\
9.05 \mathrm{E}-03 \\
1.66 \mathrm{E}-03\end{array}$ & $\begin{array}{l}1.08 \mathrm{E}-01 \\
9.04 \mathrm{E}-00 \\
2.92 \mathrm{E}-01 \\
9.60 \mathrm{E}-01 \\
1.55 \mathrm{E}-02 \\
7.49 \mathrm{E}=03 \\
4.25 \mathrm{E}-00 \\
1.10 \mathrm{E}-01 \\
1.10 \mathrm{E}-01 \\
1.08 \mathrm{E}-01 \\
9.06 \mathrm{E}=02 \\
7.02 \mathrm{E}-03 \\
1.34 \mathrm{E}-01 \\
9.04 \mathrm{E}-03 \\
1.66 \mathrm{E}-03\end{array}$ \\
\hline Totol & $5.51 E 05$ & $3.39 \mathrm{E} 02$ & $1.83 E-02$ \\
\hline
\end{tabular}

(a) $1.36 \mathrm{E}-01 \mathrm{Ci}$ is equivalent to $1.36 \times 10^{-1} \mathrm{Ci}$ 
TABLE 3-17

CHEMICAL COMPOSITION OF ZIRCALOY ALLOY $5^{49}$

Concentration, Weight Percent

\begin{tabular}{lccc} 
& \multicolumn{3}{c}{ Concentration, Weight Percent } \\
\cline { 3 - 4 } Element & Zircaloy-2 & Nominal & Typical \\
\cline { 3 - 4 } Tin & & & \\
Iron & $1.20-1.70$ & $1.20-1.70$ & 1.60 \\
Chromium & $0.07-0.20$ & $0.18-0.24$ & 0.225 \\
Nickel & $0.05-0.15$ & $0.07-0.13$ & 0.125 \\
Fe $+\mathrm{Cr}+\mathrm{Ni}$ & $0.03-0.08$ & -- & -- \\
Zirconium & $0.18-0.38$ & $0.28-0.37$ & -- \\
& Balance & Balance & Balance
\end{tabular}




\section{TABLE 3-18}

NOMINAL COMPOSITION OF INCONEL $5^{49}$

Concentration, Weight Percent

\begin{tabular}{|c|c|c|}
\hline \multirow[b]{2}{*}{ Series 600} & \multicolumn{2}{|c|}{ Series 718} \\
\hline & Minimum & Maximum \\
\hline 76 & 50 & 55 \\
\hline 0.05 & - & 0.10 \\
\hline 0.20 & - & 0.50 \\
\hline 7.20 & 11 & 22 \\
\hline 0.2007 & -- & 0.03 \\
\hline 0.20 & -- & 0.75 \\
\hline 0.10 & -- & 0.75 \\
\hline 15.8 & 17 & 21 \\
\hline - & 2.8 & 3.3 \\
\hline - & 4.75 & 5.75 \\
\hline - & 0.30 & 1.30 \\
\hline - & 0.20 & 1.00 \\
\hline
\end{tabular}


TABLE 3-19

MAXIMUM IMPURITY CONTENT OF ZIRCALOY ALLOYS

\begin{tabular}{|c|c|c|c|}
\hline \multirow[b]{3}{*}{ Element } & \multicolumn{3}{|c|}{ Concentration, pom } \\
\hline & \multirow[b]{2}{*}{ Zircoloy-2 } & \multicolumn{2}{|c|}{ Zircaloy-4 } \\
\hline & & Nominal & Typical \\
\hline Aluminum & 75 & 15 & 24 \\
\hline Boron & 0.5 & 0.5 & 0.33 \\
\hline Codmium & 0.5 & 0.5 & $<0.25$ \\
\hline Carbon & 270 & 270 & 120 \\
\hline Chromium & a & a & a \\
\hline Cobalt & 20 & 20 & $<10$ \\
\hline Copper & 50 & 50 & $<20$ \\
\hline Hafnium & 200 & 200 & 78 \\
\hline Hydrogen & 25 & 25 & 13 \\
\hline Iron & a & a & a \\
\hline Manganese & 50 & 50 & $<20$ \\
\hline Nickel & 0 & 40 (max.) & $<20$ \\
\hline Nitrogen & 80 & 80 & 39 \\
\hline Oxygen & - & -- & 950 \\
\hline Silicon & 200 & 120 & 35 \\
\hline Titanium & 50 & 50 & $<20$ \\
\hline Tungsten & 100 & 100 & $<20$ \\
\hline Uranium (total) & 3.5 & 3.5 & $<0.2$ \\
\hline Vanodium & NA & NA & $<20$ \\
\hline
\end{tabular}

- See Table 3-17 
TABLE 3-20

SOURCES AND QUANTITIES OF NON-HIGH LEVEL FUEL. REPROCESSING PLANT TRU-WASTES ${ }^{53}$

\begin{tabular}{|c|c|c|}
\hline Wastc Category & $\begin{array}{l}\text { Estimated } \\
\text { Woste Volume } \\
\mathrm{m}^{3} / \mathrm{MTHM}^{\text {(a) }} \\
\end{array}$ & Waste Description \\
\hline \multirow[t]{2}{*}{ Solt Solutions } & 0.3 & $\begin{array}{l}\text { Composited, concentrated ILLW } \\
\left(\mathrm{Na}_{2} \mathrm{CO}_{3}, \mathrm{NaHCO}_{3}, \mathrm{NaNO}_{3}, \mathrm{Na}_{2} \mathrm{HPO}_{4},\right. \\
\text { miscellaneous decontamination ogents). }\end{array}$ \\
\hline & 0.03 & $\begin{array}{l}\text { lodine scrub solutions }[0.2 \cdot 0.4 \mathrm{M} \\
\left.\mathrm{Hg}\left(\mathrm{No}_{3}\right)_{2}, 8-10 \mathrm{M} \mathrm{HNO}_{3}\right] .\end{array}$ \\
\hline
\end{tabular}

2. Precipitates and Slurries

Water treatment slurry (iron hydroxides, clays, miscellaneous precipitates).

Slurry from $U F_{6}$ off-gas treotment

(iron hydroxides, $\mathrm{K}_{2} \cup \mathrm{O}_{4}$, potassium/ calcium fluor ide, efc.).

3. Surfactant/Detergent --

Miscellaneous surfactant-containing Solutions decontamination solutions. (Volume included in I, obove.) Loundry wastes may also be included in this category.

4. Organic Liquids

0.008

Degroded TBP solvent.

0.005

Miscellaneous lubricants, oils, hydroulic fluids, lab solvents, etc.

(a) MTHM - Metric Tons Heavy Metal. Volumes are based on annual throughput of MTHM at a large ( $\sim 1500$ MTHM/yr) reprocessing plant. Amounts ore representative of typical focilities, but not all facilities will have the full spectrum of wastes. 
TABLE 3-20

(CONTINUED)

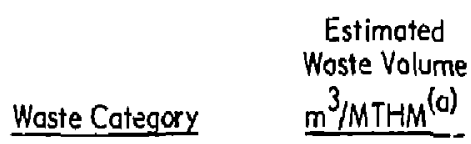

0.01

5. Wet Particulates
$0.005-0.01$

\section{Waste Description}

Bead ion exchange resins used to purify solvent and process condensates.

Adsorbents/ion exchonge minerols used for condensote and (NNH purification (silica gel, zeolites).

0.0002-0.006 lodine removal adsorbents, zeolites.

0.002

Ruthenium adsorbeni beds $\left(\mathrm{Fe}_{2} \mathrm{O}_{3}\right.$, $\left.\mathrm{SiO}_{2}\right)$

$0.034 \quad \mathrm{UF}_{6}$ adsorbent beds $\mathrm{Al}_{2} \mathrm{O}_{3}, \mathrm{NaF}$, $\mathrm{CoF}_{2}, \mathrm{MgF}_{2}$ ).

$0.038 \quad U F_{6}$ fluorinator beds and fine;

$\left(\mathrm{Al}_{2} \mathrm{O}_{3}, \mathrm{CaF}_{2}\right)$.

7. Combustible Solids $\quad 0.2$

0.9

0.16

Miscellaneous cumbustible trash (uncompacted).

Miscellaneous combustible trash (uncompacted).

Ventilation filters (up to 60 wto combustible).

8. Noncombustible Solids 0.03

General trosh.

0.02-0.4 Failed equipment, packaged deep bed filters.

TOTAL $\quad 2.6-3.0$ 
linearly from the value of 0.007 (early 1980's) to 0.0025 in 1990's, after which it remains constant. The steody-state value of 0.0025 was estimoted for largescole production.

The volume of solid alpho-containing waste which will be generated in the future is similarly uncertain and depends upon such factors as changes in regulations and incentive for volume reduction.

\subsection{ENRICHMENT PLANT OPERATIONS}

While lasei enrichment and gos centrifugation offer olternatives for future enr ichment, the present discussion is limited to the gaseous diffusion plants.

Gaseous diffusion operating experience has been very limited in terms of large throughputs of power reactor returns. Although there has been considerable production reactor material refurned to the coscade, irradiation exposure of that material hos been ten- to twenty-fold less than that for power reactors. Experience to date has indicated the following:

- A significant quantity of all non-uronium radioactivity (neptunium, plutonium, and fission products) is retained in the feed cylinder (UF, tank) and will be removed when and where the returned cylinder is washed.

- $\quad \mathrm{PuF}_{6}$ and $\mathrm{NpF}_{6}$ are easily reduced and therefore removed by tropping with $\mathrm{CoF}_{2}, \mathrm{MgF}_{2}, \mathrm{NaF}$, cryolite, etc.

- Technetium, compared to other fission or alpha emission products, is less likely to be removed by any process. Experience at Oak Ridge Gaseous Diffusion Plant indicates that technetium release to the environment would be 10 percent of feed to the liquid effivent and or . percent of feed to the gaseous effluent.

- Experience also indicates that other fission products and alpha radioactivity release fractions should be no more than one-tenth of that for technetium. Measurernents of goseous and liquid effluents have failed to identify any other sission products. However release froctions of one percent to the liquid effluent and 0.1 percent to the gaseous effluent for other fission products will be used below to estimate environmental releases. 
- Coboltous fluoride trops exhibit deconiamination foctors of 400 for neptunium and $10^{5}$ for plutonium prior to feeding to the coscode a conversion focility.

- A large portion of the radioactivity entering o settling pond will be entroined in the sludge of the pond.

The bilk of the rodionctivity will be released as solids, either entrained on odsorbate or equipment removed from service for disposal. Liquid waste will be generated by rinsing (decontaminution) of recycled equipment. The first rinse solution, which contains the bulk of the rodioactivity, is saved to be used as the dilute ocid wash solution. Subsequent rinses are sent to the primory holding pond.

Gaseous wastes can result from purge system venting, venting of evoporator overheads at the uranium recovery focility, and venting of decontamination hoods in the recycle focility. However, the exact breakdown for retention and release factors for each step is not known. One can only moke assumptions bosed on experience with gaseous diffusion. The limited experience ovoilable wos used to arrive at the estimates in Toble 3-21 about goseous, liquid, and solid dischorges for non-uranium radioactivity. It is worth niting that the Paducah Gaseous Diffusion Plant dia generate and dispose of 2.6 cubic meters of waste containing 0.277 kilograms of TRU isotopes.

\subsection{OTHER POTENTIAL SOURCES}

\subsubsection{LIGHT-WATER REACTOR WASTE ${ }^{21}$}

A logical source of TRU waste would appear to be the radwaste generated by the present generotion of operating LWRs. However, as painfed out below, all studies and evaluation have shown TRU content below the $10 \mathrm{nCi} / \mathrm{gram}$ limit and substantially be' 'w the anticipated limit which should be an order af magnitude or more higher concentration of TRU isotopes. 


\section{TABLE 3.21}

ASSUMED DISTRIBUTION OF FISSION PRODUCTS

AND TRANSURANIUM ISOTOPES TO ATMOSPHERE,

PRIMARY HOLDING FOND, AND BURIAL GROUND

\begin{tabular}{|c|c|c|c|}
\hline Isotope & $\begin{array}{c}\text { Fraction } \\
\text { Releosied } \\
\text { to Atmosphere }\end{array}$ & $\begin{array}{c}\text { Froction } \\
\text { Released } \\
\text { to Primary } \\
\text { Molding Pond } \\
\end{array}$ & $\begin{array}{c}\text { Froction Input } \\
\text { to Buriol/Storoge }\end{array}$ \\
\hline$N p-237$ & $2 \times 10^{-7}$ & $4 \times 10^{-6}$ & $\sim 1.0$ \\
\hline Other Transuronium & $8 \times 10^{-10}$ & $1.6 \times 10^{-8}$ & $\sim 1.0$ \\
\hline Tc-99 & 0.01 & 0.10 & 0.89 \\
\hline Fission Products & 0.009 & 0.01 & 0.989 \\
\hline
\end{tabular}


Prior meosurements of the levels of transuranics in rodwoste are sparse. Westinghouse (HEDL) made some measurements of activities in one somple each of evaporator botloms, resin, and filter cortridges from a reoctor coolont system, fuel pool, and wasle holding tank from an unnomed PWR. Only gross alpha counts were made, and the results reported were only that each sample contained less than $10 \mathrm{nCi} / \mathrm{gram}$.

A study by Domes \& Moore for EPA and the New York State Energy Reseorch and Development Authorify examined wosfe frorn four reactors in New York State: Fitzpotrick, Nine-Mile Point, Cinna, and Indion Point Unit $\$ 2$. In this study, somples of evaporator bottoms were taken from all four sites and no plutonium, americium, ar uranium wos found in any of the samples with reported detection limits of $0.1 \mathrm{nCi} / \mathrm{gram}$. No onalysis results were reported for curium octivities on any of the samples from these four plants. Samples of spent resin were taken from Nine-Mile Point and Ginna. No tronsu:anic activities were found in the sample from Nine-Mile Point within the quoted detection limit. In the somples from Ginno, activities for $\mathrm{P}^{\prime}-238, \mathrm{Pu}-239$, and $\mathrm{Am}-241$ were found of $0.4,0.8$, and $0.7 \mathrm{nCi} /$ grom, respectively. Additionally, some filter sludge ond smear somples of filters were taken from each of the plants. Activities of Pu-238 and Pu-239 were found on these samples from Nin-Mile Point and Ginna. The activity levels were below $/ \mathrm{nCi} /$ sample.

General Electric made some anolyses of reactor woter insolubles and scropings from fuel rods at Manticello in 1973. They found total activities of tronsuranics of from 1.5 to $9 \times 10^{-4} \mathrm{nCi} / \mathrm{gram}$ of reoctor water with nearly 95 percent of the octivity being $\mathrm{Cm}-242$, about one percent $\mathrm{Cm}-244$, and the remainder equally divided between Pu-238 and Pu-239+240. The fuel scropings showed on olmost identical nuclide distribution and total alpha levels of about $100 \mathrm{nCi} / \mathrm{cm}^{2}$ on the rod surfoces.

In 1975, three samples of reactor coolant from Indian Point Units $\# 1$ and $\# 2$ were anolyzed for Power Aithority of the State of New York (PASNY) by ERDAJHASL. The results showed the presence of Pu-238, Pu-239+240, Am-24I, $\mathrm{Cm}-242$, and $\mathrm{Cm}-244+243$ at levels varying from $10^{-6}$ to $10^{-4} \mathrm{nCi} / g r a m$ of 
reactor coolant. The biggest axtivity level was that of Cm.242. Nass spectrometr was used to identify the Pu-23\%+Pu-240 activity as being $2 / 1$ in favor of Pu-23\%. From Unit $\| 1$, the $\mathrm{Cm} \cdot 242$ activity was about 80 percent of the iolol, whereas from the Unit $1 / 2$ decay heat loop Cm-242 represented obout 45 percent. in each case. the bulk of the remoining activity was split hetween $\mathrm{Pu}-238$ and $\mathrm{Pu}-239+240$.

Studies have been made for the I.PRC of transuranics in sediments and biological specirmens in and around the discharge creas by the Woods Hole Oceonographic Institute. Aiaine Yonkee. Pilgrirn. A'illstone Point. and' Inlvert Cliffs were included in this study. At present, the only plutonium that can be associated with a plant discharge has been fourd! in a quarry that serves as the vischarcle conol for the Nillstone Point complex. The levels reported for the quary were about five times the background level from fallout.

In onother progrom sponsored by the litRr, two samples of concentrated waste. once of spert resin and one of centrifuge sludg: token from Oyster Creek. were analyzed for trar suranics. In addition. two samples eoch of spent resin were

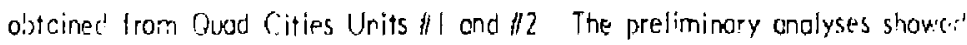
sor: e inconsistencies in the results. and the analyses ore scheduled to he redone.

3.4.2 WEDICAL. APPLICATIOI: $5^{75}$

Isotopes with energetic emissions. such as Co 60 and Cs-137. are used in therapeutic situations where the radiation is used to destroy lacolized malir: noncies. No TRU rodioisotopes are presently utilized in these applications. Small quantities of Am-24! are utilized by various hospitals and teaching institutes. $^{86}$ Further. the current oeneration of heart pocemakers does utilize plutonium as an energy source and as such can be considered a source of TPU. contaminated waste. 
Typically, an omericium-beryllium neutron source of tive to 20 curies and a Cs. 137 gomma-ray source of several curies are used in well-logging operations. 48 Each source is enclosed inside two small. stoinless-steet cylinders, one inside the other, with welded end caps. Sources are fabricated in o hot cell by a service company. which purchases the rodioisotopes from a company having access 10 a production reactor. Thus the americium-beryllium source is a TRU vraste source.

\subsubsection{PADIOACTIVE GAUGHIG SOUPCES}

A number of different isolopes. usvally in seoled source form ond including $\mathrm{Po}$ 226. (s-137. Co.60, K.r-85. Sr-90. Ani-241. Pri-147, and Th-2(14. are used in incividual radioactive gauging sources, which contain from a few millicuries up. to severol curies of activity. The rationctive materials used by the sourc manufacturers cre abtained from suppliers of hy-product material.

\subsubsection{RADIOISOTCPE THERM OELECTPIC GE'IEP.ATOIS}

Crri-244 is a potentially economic fuel material in heat sources for radioisolepe thermolectr ic generators. when recovered from LW.P. spent fuel. Fequirell, nts for the curium include 97 percent minimum product purity.

\subsubsection{OTHEP NUCLEAR POWEP APPLICATIOI \$S}

The Naval Nucleor Propulsion Progrom uses highly enriched uraniul: ( >90 percent U-235) in o PWR system. Like other reactor types. uraniu'.. : enriched as UF ${ }_{6}$ by gaseous diffusion for fabricotion into fuel elements. Recouss very little $U-238$ is present in the fuel. only very small quantities of plutor : irr: are produced by neutron irradiation in the reactor. The recovered U-235 is reens iched for recpplicotion to the fuel cycle. 


\subsection{DOE TRU WASTE CHARACTERISTICS $68,28,77,92$}

This section summarizes available data on the characteristics of the transuranic (TRU) waste that was (and still is being) produced by defense programs (primarily nuclear weopon production) and olher DOE octivities. ${ }^{T \cdot} \cdot$ ase programs were conducted originally under the auspices of the Atomic Energy Commission and are now under the Department of Energy. TRU waste is defined os waste other than the legally defined, high-level woste that contains more than 10 nanocuries of transuranic alpha-emitting radionuclides per gram of waste. Characteristics of interest include quantity of transuranics per waste container, dose rate at the container surface, and the forms of the waste.

The DOE focilities represent a number of different types of operations and cover the major producers of solid tronsuranic waste and the disposal or starage sites. The Hanford complex includes several contractors performing both production work and research and development wark with plutonium. The major contractors include the Battelle Northwest Laboratory ( $\mathrm{B} i \mathrm{iWL}$ ), engaged in research and development on many aspects of nucleor energy technology as well as studies in non-riuclear areas; the Atlontic Richfield Hanford Company (ARHCO), which operates the separations plants and the waste disposal and storage facilities; and the Hanford Engineering Development Laboratory (HEDL), which carries out research and development work on advanced reactor fuels including those for the fost flux reactor. Mound Laboratory is primarily engaged in production and research work associated with $P_{U-2} 238$ heat sources for space and terrestrial applications. Savannah River is the mojor plutonium praduction plant since the Hanford reactors were shut down. In addition, Sovannah River produces and purifies the Pu-238 used for heot sources and maintoins the DOE facilities for recovery of this material from high-level scrap generafed af other locotions. Rocky Flats produces plutonium metol shapes and includes focilities for recovery of scrop. LASL is a research and development laboratory of broad atomic energy scope, including studies of the properties of the plutanium isotopes. Limited processing facilities are associated with LASL work to permit development of processing improvements and the provision of special items required for other reseorch. The INEL complex includes the capability for the recovery of uranium 
and plutenium from irrodiated fuels. However, liflle Iransuranic waste is generated at this site, and is primarily orienter, owards the disposol and storage of TRU waste. ${ }^{25}$ Appendix F presents a detoiled discussion of the various DOE facilities and woste forms generation.

There are four sources of DOE TRU waste: currently produced waste, retrievably stored waste, buried waste, and decontamination and decommissioning (d\&d) waste. The currently produced and the retrievobly stored wastes are, by for, the best characterized and documented. Much less is known about buried TRU wostes; olthough there ore estimates of volumes invoived, they may be off by as much as a factor of 1wo. The dad waste is the most poorly characterized. If the 740 DOE facilities which are currently listed as surplus, or are likely to become surplus in the next few years, were decommissioned, the volume of IRU woste generoted might ronge from $1.4 \times 10^{5}$ to $2.7 \times 10^{6}$ cubic meters. $^{68}$

\subsection{DESCRIPTION OF TRU WASTE STREAMS $25,28,68$}

The existing unprocessed varieties of DOE defense-related TRU wastes are listed in Table 4-1. Table 4-2 describes some of the physical characteristics of existing DOE TRU wostes, while Appendix F provides detailed information concerning DOE-generated wostes.

Solid wastes cansist of a wide variety of materiols originating from different places in o given work area. In order to provide some description of the general types of woste matrices generated and the voriability of their contents, an attempt was made to classify the waste streams into several categories so that these could be reviewed as individual entities.

\subsubsection{LABORATORY TRASH (ROOM TRASH) ${ }^{25}$}

This waste consists of the miscellaneous materials which are used in the laboratories or rooms outside of the direct process enclosures. It vories in composition from day to day and from room to room, depending upon the type of 
TABLE 4-I

EXISTINC DOE DEFENSE-RELATED TRIANSURAINIC WASTES ${ }^{28}$

A. Absorbent Papers and Rogs (Dry and Moist)

Protective Clothing, Wood, Other Cellulosics

Plostics, Rubbers

B. Ion Exchonge Resins Processing Sludges Solt

Cake Incinerotor Ashes Above, Cement

Stabilized

C. Spent Machinery, Tools Process Vessels

Contominated Building Moterials, Rubble

Scrop Loborotory Equipment, Glass

Contarninated Concrete and Asphalt

D. Contaminated Soils trom Burial Trenches 
TABLE $4-2$

PHYSICAL CHARACTERISTICS OF DOE TRU WASTES 28

\section{Packoging:}

Mild steel drums, 208-lifer DOT $17 \mathrm{C}$

Fiberglass reinforced plywood box, $1.2 \times 1.2 \times 2.1 \mathrm{~m}$, DOT 7A

Metal bins, approx. $1.2 \times 1.5 \times 1.8 \mathrm{~m}$, DOT $7 \mathrm{~A}$

Others acceptoble

Surfoce Dose Rates:

Average $: 10 \mathrm{mrem} / \mathrm{hr}$

If $>200 \mathrm{mrem} / \mathrm{hr}$, remote handling required

Actinide Contamination Limits:

(weapons grade Pu equiv.; Pu-238,-239,-240, U-233,-235

Average $\leq 10 \mathrm{~g} / \mathrm{drum}$

Maximum 200g/210-liter drum

$$
350 \mathrm{~g} / \mathrm{M}^{3} \text { in DOT } 7 \mathrm{~A} \text { boxes }
$$

$200 \mathrm{~g}$ weapons grode $\mathrm{Pu}-15 \mathrm{Ci}$ (alpha) $\approx 4 \times 10^{5} \mathrm{nCi} / \mathrm{g}$ of waste

\section{Thermal Power Output: (Contact-Handled TRU)}

Negligible to approx. 3.5 watt 
work being carried out and, possibly, on the work habits of the operator. Becouse the contamination level is normally low, it is difficult or impossible by present techniques to assay the material for contamination; much of it is therefore discarded as nonretrievable waste ( $<10 \mathrm{nCi} / \mathrm{g}$ ). It mokes up the bulk of the combustible wastes so that the composition is of considerable interest in defining further steps needed in an overall volume reduction progrom.

An estimote of the composition of the waste motrix was obtained from various DOE focilities (Table 4-3). These values are to be regarded only as opproximotions of the long-term overall average because of the voriations noted above.

\subsubsection{LINE-GENERATED TRASH ${ }^{25}$}

The line-generoted frash consists of miscellaneous materiols which are used inside processing enclosures, such os glove boxes. At most sites, the composition is similar to that of the room-generated trash, having o relatively high fraction of combustible material. However, the contamination level is usually considerably higher than that of the room-generated trosh. Some partion of the more highly contominated material will be recycled for recovery of the transuranic elements with reduction usually by incineration and leaching of the ash. The residue from such processes is included in the line-generated trash. A summory of the composition of this waste category of each locotion is given in Table $4-4$ with the same caveot about the accuracy os wos given for the room* generoted trosh.

\section{I.3 LIQUID EFFIUUENT TREATMENT SLUDCES 25}

At Los Alamos, Rocky Flats and Mound Laborotory, the aqueous effluents are treated by a precipitation process to remove radioactive contaminants to such a level that the remaining water can be discharged to the environs. The contaminants carried in these effluents are transferred to the precipitate or sludge, which then forms the "solid" tronsuranic waste. At Savannah River and Hanford the liquid effluents are not treated but are disposed of by other means. Hanford is planning to treat animol excrements in the future by the production 
TABLE 4-3

ESTIMATED COMPOSITION OF LABORATORY TRASH (WEICHT PERCENT) 25

\begin{tabular}{|c|c|c|c|c|c|}
\hline Material & Hanford & LASL $^{*}$ & Mound & $\begin{array}{l}\text { Rocky } \\
\text { Flots } \\
\end{array}$ & $\begin{array}{l}\text { Savannah } \\
\text { River }\end{array}$ \\
\hline Paper and rags & 18 & 46 & 50) & 30 & 53 \\
\hline Rubber & 15 & 7 & 25 & 20 & 25 \\
\hline Plostics & 20 & 9 & 20 & 50 & 4 \\
\hline Glass & I & 17 & - & -- & - \\
\hline Metal & 30 & 21 & -- & - & - \\
\hline Miscellaneous & 16 & - & 5 & -- & 13 \\
\hline
\end{tabular}

* Data obtained from a sorting experiment involving $1,100 \mathrm{~kg}$ of trash from six loboratory locations considered to be representative of the overall laboratory trash, not just the plutonium processing facilities. 
TABLE 4-4

ESTIMATED COMPOSITION OF
LINE-GENERÁTED TRASH (WEIGHT PERCENT) $)^{25}$

\begin{tabular}{|c|c|c|c|c|c|}
\hline Materiol & Hanford & LASL & Mound & $\begin{array}{l}\text { Rocky } \\
\text { F!nts }\end{array}$ & $\begin{array}{c}\text { Sovannah } \\
\text { River }\end{array}$ \\
\hline Poper and rogs & $a$ & o & + & 16 & 35 \\
\hline Rubber & + & + & + & 15 & 30 \\
\hline Plastics & $+b$ & + & + & 36 & 35 \\
\hline Miscellaneous & $-\infty$ & -- & -. & $33^{c}$ & -- \\
\hline
\end{tabular}

+ Indicates this moterial to be a major fraction but estimated percentages not ovailable.

- Generally incinerated for plutonium recovery; leoched residue becomes port of woste.

b Polyethylene bottles and lucite glove box windows.

c 6 percent wooden filter fromes; 5 percent liquid (woter and acids); 4 percent metals; and I percent usbestos filter material. 
of aluminum hydroxide sludge following initial biological treatment in a septic tank.

At Los Alamos two treotment plonts ore in operation. The first is the central plont for the laboratory complex, while the second treats the wastes from the plutonium processing site. In both cases the treatment process employs a precipitation step using ferric sulphate corrier, lime, trisodium phosf iote, and a coagulent aid. At the central liquid waste treatment plant, which serves most of the laboratory buildings, the sludge, which contains ferric hydroxide, colcium phosphate, and calcium carbonate, is vacuum filtered on diotomoceous earth. This sludge contains 35-40 percent solids with activities of 90 percent Pu-238 and 10 percent $\mathrm{Pu}-239$. The liquid effl its from this process may be passed through ion exchange columns to remove strontium and cesium if these are present. The columns are regenerated with $6 \mathrm{~N}$ nirric ocid which is neutralized with sodium hydroxide. The strontium is precipitated with sodium carbonote, lime, ferric sulphote, and strontium nitrote; and the sludge is then inclu lo. in the retrievable wastes. The sludge from the plutonium processing plant efflur treatment along with vorying quantities of neutralized strip waste, and SII quantities of other solutions, is mixed with cement for disposal.

At Mound Laboratory the tronsuranic oqueous wastes are treated by precipitotion, flacculation, and settling to produce a sludge which is mixed with cement.

At Rocky Flats the treatment is similar to that at Los Alamos with the :esulting sludge being neutral to slightly basic. These sludges are mixed with cement to produce o waste containing dictomaceous earth, water, and metal hydroxides, nitrates and chlorides.

\subsubsection{OILS, GREASES AND COMBUSTIBLE LIQUIDS $S^{25}$}

Oils and combustible liquids ore used as lubricants for equipment or machining and as solvents. These materiols, which moy become contaminated during use, comprise a waste stream of some importance because of their generally mobile and frequently flammable noture. Although they are usuolly liquids in their row 
form, oils and solvents are included in this survey becouse they are frequently mixed with a sorbing solid and placed in the same channels for disposal or storage as the solid wastes. At several of the sites visited a portion of the oils and solvents was burned. Nancombustible silicone-type fluids are finding increased use os lubricants in plutonium processing operotions. When contaminated, these are, for the most port, disposed of by means of absorption onto inert materials, followed by storage with other solid transuranic wastes.

At Hantord the major source of oils was vocuum pump oil, with some machining and cutting oils. Hanford also has an occumulation of lard oil. At Los Alames the vocuum pump oil ogain represented the lorgest volume but with contributions from Dow Corning Dielectric fluid 200 (dimethyl silicone) for heat treating, Mobil Vactro 12 hydraulic fluid for the computarized lathe, and John Craine Lupping Vehicle 3-M contsining suspended silicone corbide. Rags socked with oils or solvents also originate in the dry boxes at this location. Similar types of oils and solvents ore found of Rocky Flats with Lothe coolant being the major constituent. Several drums of paint thinner are being held on-site pending a decision as to their disposol. At Sovannah River the tributyl phosphate with a kerosene diluent used in the solvent extraction process is the primary source of combustible liquids. The small amount of other oils is mixed with the kerosene for burning.

\subsubsection{EQUIPMENT AND METAL5 25}

At all locations, discarded equipment constitutes o significant portion of the wastes. At most of the sites, small items which will fit into the solid woste packoge are handled along with the room- or line-generated trast. A more troublesome problern is the large equiprnent such as glove boxes, obsolete lathes, and similar massive devices, They ore neither easily reduced in size nor easily manitored for contomination. In some coses, it would be possible to store this equipment for future use in contominoted work. However, the lack of adequote warehouse facilities for such potentially contaminated items and the regulations on the length of time that unused equipment can be stored essentially preclude its reuse; and the equipment is discarded as waste. Rocky Flats has a size 
reduction operation for breakdown and decontamination of equipment and machinery.

\subsubsection{BUILDING DEBRI5 25}

Building debris covers a wide variety of materials including building materials and built-in equipment such as blowers and filter housings. It results either from the renovation of a building or portion of a building or from the complete demolition of a structure which has lost iis usefulness. Thus, it is characterized by its intermittent occurrence and by the diversity of materials found in the matrix. This type of waste may assume greater importance in the future as current focilities are decommissioned or are upgraded to meet new, more rigorous, safety standards.

\subsection{TRIJ WASTE FORMS}

The forms in which woste comes is of considerable importance in assessing operationol and lang-ferm risks. The combustibility and dispersibility of the waste are important factors in operational accidents. The tendency of waste to produce gas and its susceptibility to leoching ore important foctors in long-term risk assessments. 68

It is estimated that between 20 and 2.5 percent of the waste by volume in retrievable storoge ot Idaho, excluding the woste retrieved from the burial grounds, is combustible. At Savannah River, about 60 percent of the 354 cubic meters of waste generated by them since July 1, 1974, and about 10 percent of the 255 cubic meters of the Pu-238 waste from Mound Loboratory and LASL are combustible. ${ }^{5}$ These data should be used with caution because there seems to be o consensus that, in spite of regulations, considerable rnixing of combustibles and noncombustibles occurred in the past. ${ }^{68}$

Many of the DOE TRU waste generators have developed fairly detailed codes to describe the various waste forms in their containers. Tables 4-5, 4-6 and 4-7 list, in order of contribution the top ten contributors to the volume, weight, and 
TABLE 4-5

RANK ORDERING OF WASTE FORMIS BY VOLUME FOR WASTES STORED AT IDAHO

FROM SEPTENBER I, 1971 , TO DECEMBER 21, $1976^{68}$

Ronk

Waste Form

iMetal scrap

Paper and rags - dry

Paper and rags - wet

Filters - CW'S

5 Second stage sludge

$\underline{f}$

6 LSA metol, glass, etc.

7 First stage sludge

8 Organic setups (solidified oils)

9 Unknown

10 Concrete, asphalt, etc.

Average for all waste forms

\section{t6 of \\ Total \\ volume}

36

9

7

7

6

5

5

3

3

2

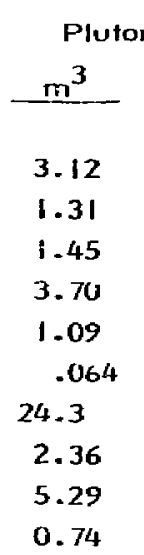

\begin{abstract}
Cuntent
$\mathrm{g} / \mathrm{kg}$
\end{abstract}

$7.5 \times 10^{-3}$

$3.7 \times 10^{-3}$

$3.3 \times 10^{-3}$

$13.9 \times 10^{-3}$

$0.9 \times 10^{-3}$

$0.2 \times 10^{-3}$

$22.7 \times 10^{3}$

$2.2 \times 10^{-3}$

$18.3 \times 10^{-3}$

$0.7 \times 10^{-3}$

$6.37 \quad 11.9 \times 10^{-3}$

Density*

$\mathrm{kg} / \mathrm{m}^{3}$

Fraction

of Volume

in Urums

416

352

0.04

0.50

0.98

0.01

1.00

$0.0 z$

1.00

1.00

1.00

0.33

544

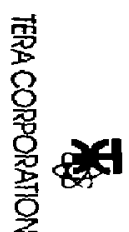

* The volume of waste assumes the nominal contuiner volumes and the weights of the containers are included. In addition to plutonium, first stage sludge contains an average of $953 \mathrm{~g} / \mathrm{m}^{3}$ and $8.8 \times 10^{3} \mathrm{~g} / \mathrm{kg} \mathrm{Am-24l)}$. 
TABLE 4-6

RANK ORDERING OF WASTE FORMS BY WEIGHT FOR WASTES STORED AT IDAHO FROM SEPTEMBER 1, 1971 , to DECEMBER $31,1976^{68}$

\begin{tabular}{clc} 
Rank & \multicolumn{1}{c}{ Woste Form } & $\begin{array}{r}\text { \%of } \\
\text { Totol } \\
\text { Weight }\end{array}$ \\
& Melal scrop & 28 \\
2 & Second stoge sludge & 12 \\
3 & First stage sludge & 9 \\
4 & Organic setups (solidified oils) & 6 \\
5 & Paper and rags - dry & 6 \\
6 & Poper and rags - wet & 5 \\
7 & High-level sludge/cement & 4 \\
8 & Concrete, asphalt, etc. & 4 \\
9 & LSA, metol, glass, etc. & 3 \\
10 & Filters - CWS & 3
\end{tabular}

*High-level sludge/cement is generated by Mound Laboratory. Hence the plutonium is heat source rather than the weopon plutonium. 
TABLE 4-7

RANK ORDERING OF WASTE FORMS BY PLUTONIUM CONTENT

FOR WASTES STORED AT IOAHO
FROM SEPTEMBEER I, 1971, TO DECEMBER $31,19766^{68}$

\begin{tabular}{clc} 
Rank & \multicolumn{1}{c}{ Waste Form } & $\begin{array}{r}\text { \%o of } \\
\text { Total } \\
\text { Pu Cont }\end{array}$ \\
\cline { 3 - 3 } 1 & Metal scrap & 18 \\
2 & First stage sludge & 17 \\
3 & Leaded rubber gloves ond aprons & 9 \\
4 & Metal - leached & 9 \\
5 & Raschig rings unleoched & 7 \\
6 & Insulation and CWS & 4 \\
7 & Graphite & 4 \\
8 & Filters - CWS & 4 \\
9 & Cement insulation & 3 \\
10 & Gloss & 3
\end{tabular}


plutanium confent for waste stored of Idaho between September 1, 1971, and December 31, 1976. These ten waste forms occount for about 80 percent of the totals. In developing this ranking, no effort was made to combine waste forms with similar descriptions. Table 4-5 also gives the volume fraction of each woste form that is in drums; the remainder being in boxes. 68

The rank orderings in Tables 4-5, 4-6 and 4-7 provide voluable insights on the character of the waste stored at Idaho or, more specifically, of the waste generated by Rocky Flats since all but one of the waste forms was generoted by Rocky Flats. The following observations can be made. ${ }^{68}$

- The plutonium concentrations of the different waste forms vary widely. The plutonium concentrations for the waste forms on the volume and weight rankings range over two orders of magnifude. Inclusion of waste forms in the plutonium content ranking adds onother order of magnitude to the range.

- A large portion of the waste, by either wegight or volume, has a gross density of 320 to $480 \mathrm{~kg} / \mathrm{m}$. Low-density wastes ore those waste forms with on inherent low density, such os paper and rags, and those with a high-void fraction such as scrap metal. High density wastes are predominately sludges. The gross densities listed in Table 4-5 are nat the actual densities of the waste forms because the actud weights and volumes of the waste in contoiners were not used in calculoting the densities. The volumes that were used were the gross volumes of the containers with no ollowance for practical fill froctions, and the weights that were used included the weighis of the coniainers.

- With the exception of scrap metal, the waste forms in the plutonium content ranking ore characterized by small to moderate quantities (only three appear in the weight and volume rankings) of waste that contain very high plutonium concentrations. Eleven percent of the waste by volume or seven percent by weight contains 60 percent of the plutonium.

- Scrop metal, ronking first in all three cotegories, is a relatively benign waste form because it is not combustitle and produces little gos. However, its hozard potentiol is somewhat increased becouse most of it is packaged in combustible gas-producing Rocky Flats plywood boxes. 
- The typical combustibles, such os poper and rogs, tend to have plutonium concentrations that are lower than overoge by a factor of obout three. This mitigates their hazard potential somewhat in the event of fire as well as their potentiol for generoting gos.

- First stoge sludge presents a relatively law short-term hozard becouse it is noncombustible and is packoged in steel drums. However, its high plutonium content ond high water content, may create a significant potential for producing gas.

- From Table 4.5 it is evident that certain waste forms are placed almost exclusively in either boxes or drums.

- The overage density and plutonium concentrations for all woste forms should not be used to calculate the overoge weight or plutonium content of a box or drum. Based on the overoge volues on overage box should contain 20 grams of plutonium and weight $1,727 \mathrm{~kg}$. Actualiy on overoge box contains about 7 grams of plutonium and weighs obout $1,273 \mathrm{~kg}$.

During the yeors 1954 through 1970 , opproximately $65,000 \mathrm{~m}^{3}$ of waste contaminated with transuranic elements were buried at Idaho's Radioactive Waste Management Complex (RWMC). This includes about 149,000 steel drums and 17,000 cartons and boxes. An additional $14,000 \mathrm{~m}^{3}$ of beta-gamma waste are intermixed with the transuranic (TRU) waste. Since the beta-gamma woste connot be identified and segregated from the TRU waste, the beta.gammo waste will have to be retrieved, handled, and processed with the TRU waste. While retrieving the buried waste, it is certain that soil has or will become contominoted and hove to be incorporated with the woste. Estimates of the volume of soil included with a cubic meter of waste range from 1 to $2 \mathrm{~m}^{3}$. 55 Table $4-8$ presents the estimated composition of the waste af Idaho.

The existing waste forms in Table 4-1, part A, present several potential concerns or problems: these inhamageneous materials are combustible and are subject to rodiolytic, thermal, and bocterial degradation mechanisms which yield gases, water, and residual arganic products. These products may also serve to enhance radionuclide migration. Waste forms in Table 4-1, part $B$, contain significant amounts of sorbed woter which will, in time, be ieleosed. Cement stabilized 
TABLE 4-8

ESTIMATED AVERAGE COMPOSITION OF COMBINED RETRIEVED

AND STORED TRU WASTE ${ }^{55}$

\section{Component}

Weight

Uronium sludge $\left.140 \% \mathrm{H}_{2} \mathrm{O}, 30 \% \mathrm{FE}(\mathrm{OH})_{3}, 30 \% \mathrm{SiO}_{2}\right)$

24

Buried combustibles ( $30 \%$ cordboard, 30\% plostic, $40 \%$ wood)

Buried noncombustibles ( $20 \% \mathrm{Fe}, 80 \%$ concrete)

Stored combustibles ( $30 \%$ cardboard, $30 \%$ plostic, $40 \%$ wood)

Beta-Comma combustibles ( $30 \%$ cardboard, 30\% plastic $40 \%$ vood)

Self-generated woste ( $45 \%$ plastic, $27 \%$ paper, $18 \%$ cloth, $9 \% \mathrm{Fel}$

D\&D waste (5\% cloth, $5 \%$ plastic, $90 \%$ noncombustibles)

\section{I}

Soil

Stored noncombustibles (same as buried noncombustibles)

Buried beta-gomma noncombustibles (same as stored noncombustibles)

Sodium carbor.ute

Filter cake from off gas treatment system 
processing sludges form Rocky Flots Plont, for exomple, con contoif up to about 70 weight percent of water. Spent ion exchange resins (organic) are also potentiolly degradable. Incinerator oshes from processing ore in a highly dispersable form (vio oir currents or oqueous mobilization) if not further encopsulated. Solt coke from chemicol processing (nitrote solts) is very soluble, has a moderote water content, generotes gases, and can be quite corrosive to waste pockoging materiols. 28

The contaminjted waste materiols in Table 4-I, parts $C$ and $D$, are not amenable to simple processing. Most of the contamination on these wastes is on the surfoce, being more amenable to leaching. Metallic woste materials con corrade, potentiolly yielding significant quantities of gos. These wostes oppeor, hovever, more stable for isolation than the combustible, organic varieties.

The potential waste matrices hove been tested or utilized for encopsulating lowand intermediate-level wastes (see Appendix C, D and E). Such homogeneous matrices genera!ly have o low leachability and are more readily characlerized. Glass encopsulation of TRU incinerator ash is under development at the Rocky Flats Plant. Reaction of clays with contaminated solt cake to form a ceramic matrix is being studied at Rockwell Hanford. Encapsulation of TRU incinerator oshes in concrete is being evaluated of Sovannah River Loboratary. Concerns regarding concrete relate to radiolytic and thermal degradation of the free and bound water which yields gos and water. Bitumen encapsulation of radionctive salts and residues (low-level, non-TRU, predominantly) has been used and studied extensively in Europe for approximately ten years. Concerns regarding bituminization include flammability, microbial degradation, enhanced migration capacity of leached radionuclides due to organic degradation byproducts, and alpho radiolysis producing gas.

\subsection{TRANSURANIC ISOTOPE CONTENT AND CONTAMINATION LEVELS $5^{25,68}$}

Vorious different processes operated by DOE, each with a specific isotopic makeup, generate TRU waste. In general, waste from a given process will not be 
mixed with waste from other processes. Although nol all processes hove been identified, some characteristics of the major ones con be described.

\subsubsection{WEAPON PLUTONIUM}

A large portion of all TRU woste is generated in yorious processes associated with the fabrication of nuclear weopons. Toble 4-9 lists typical isotopic content of weapon plufonium and indicates the potential TRU isotopes which may be encountered in woste from weopon fabrication.

The weight froction is dominated by the $\mathrm{Pu}-239$. The $\mathrm{Pu}-241$ dominates the curie content which determines if waste quolifies os TRU waste Igreoter than $10 \mathrm{nCi} / \mathrm{g}$ ) or as Low Specific Activity (LSA) material (less than $100 \mathrm{nCi} / \mathrm{g}$ ). (Becouse $\mathrm{Pu}-241$ is a short-lived beta emitter it does not have to be included.but apparently is in colculating TRU content.) Finally, 60 kev gammo roys from Am-24l account for a large portion of the surfoce dose. The weight froction of Pu-239, os shown in Toble 4-9, will not vary more than o few percentoge points from sample to somple. However, the Pu-24I and Am-24I froctions are not known as well and vary significantly with time.

\subsubsection{HEAT SOURCE PLUTONIUN}

Heat saurce plutonium is used to fobricate radioisotope tharmoelectric generators. Toble 4-10 lists the typical isotopic content of plutonium produced for this purpose. This table identifies the major TRU isotopes which moy be encountered in fabrication wastes. Unlike weapon plutonium, the $\mathrm{Pu}-238$ dominates both the weight fraction and the curie content.

\subsubsection{HEAT SOURCE CURIUM}

Savonnah River Loborotories has conducted several compoigns to create Cm-244 for use as heat sources in radioisotope thermoelectric generators. No isotopic breakdown is availabie. Unlike the two categories discussed above, curium wastes tend to contain a considerable amount of fission products and are, 


\section{TABLE 4-9}

ISOTOPIC COMPOSITION OF WEAPON PLUTONIUM ${ }^{68}$

$\begin{array}{lll}\text { Isolope } & \begin{array}{c}\text { Weight } \\ \text { Fraction }\end{array} & \text { Ci/gPu } \\ \text { Pu-238 } & 0.0003 & 0.005 \\ \text { Pu..239 } & 0.939 & 0.058 \\ \text { Pu-240 } & 0.057 & 0.014 \\ \text { Pu-241 } & 0.003 & 0.347 \\ \text { Pu-242 } & 0.0003 & 0 \\ \text { Am-241 } & 0.0002 & 0.0006 \\ & & 0.424\end{array}$


TABLE 4-10

ISOTOPIC COMPOSITION OF HEAT SOURCE PLUTONIUM ${ }^{68}$

\begin{tabular}{lll} 
lsotope & $\begin{array}{c}\text { Weight } \\
\text { Fraction }\end{array}$ & Ci/gPu \\
Pu-238 & 0.802 & 13.95 \\
Pu-239 & 0.159 & 0.01 \\
Pu-240 & 0.0302 & 0.007 \\
Pu-24i & 0.0064 & 0.72 \\
Pu-242 & 0.0013 & 0 \\
\hline
\end{tabular}

14.7 
therefore, placed in Sovannah River concrete boxes whirh provide considerable shielding.

\subsubsection{THORIUM FUEL CYC!.E}

Bettis has a program to develop a breeder reactor based on the thoriumuronium-233 fuel cycle. Although U-233 is not a tansuranic, it is of ten included in the definition of TRU woste. No isotopic braokdown is ovailoble.

\subsubsection{MISCELLANEOUS SOURCES}

Some waste does not fall into any of the categories discussed, insch of this miscellaneous woste is probobly ossociaint with the creotion of specific transuronic isotopes such os $\mathrm{C} f-252$. Also, there are activities which con alter the isotopic content of one of the obove processes. For insiance, the process at Rocky Flats that creotes first stage sludge greatly increases the Am-24l content of the woste.

Table 4-11 lisis praducers of various cutegories of waste.

Table $4-12$ lists the totol weight of the vorious tronsuranic isotopes in retrievable storage at Idaho as of December 31, 1977, and Savannah River as of October 1, 1977. About 90 percent of the Pu-238 of Sovonnah River originally come irom either Mound Loboratory or Los Alcmos. Over $10 \mathrm{~kg}$ of the Am-241 of Idaho is in the firct stoge sludge generoted by Rocky Flots.

Eoch process category listed can include many different activities that generate waste including creating and refining the material, fobricating the weapon, heat source; or fuel assembly that uses the material, and recovering the material from obsolete assemblies. Although thu isotopic fraction of the content may not be affected by these activities, the chemical form and the totol quantity of the tronsuranics may vary drastically from container to container. Little dato hove been found an the chemical form of the transuranics. There is some inforination on how the TRU content vories from packoge to pockoge. Figures 4-1 and 4-2 
TABLE 4. 11

PRODUCERS OF DEFENSE TRU WASTE BY CATEGORY 68

\begin{tabular}{llll} 
Weopon & $\begin{array}{c}\text { Heat } \\
\text { Source }\end{array}$ & $\begin{array}{c}\text { Heat } \\
\text { Source }\end{array}$ & Thorium \\
Producer & $\mathrm{Pu}^{\mathrm{Pu}}$ & $\mathrm{Crm}$ & U-233 \\
\hline
\end{tabular}

Hanford

?

$x$

Sovannah River

$x$

$\mathbf{x}$

$x$

$x$

Los Alamos

$x$

$x$

Oak Ridge

$x$

Rocky Flats

$?$

$x$

$x$

Mound Lobs

$x$

Argonne

$x$

Bettis

$x$ 


\section{TABLE 4-12}

TRANSURANIC CONTENT OF IDAHO AND
SAVANINAH RIVER TRU WASTE IN RETRIEVABLE STORAGE

$\begin{array}{lrr}\text { Isotope } & \begin{array}{r}\text { Idaho } \\ \text { (grams) }\end{array} & \begin{array}{c}\text { Sovannoh } \\ \text { River } \\ \text { (grams) }\end{array} \\ \text { Am-241 } & 14,500 & 330 \\ \text { Cm-244 } & 14 & 15,000 \\ \text { Pu-238 } & 1,000 & 32,000 \\ \text { Pu-239 } & 190,000 & \\ \text { Pu-240 } & 13,000 & \\ \text { Pu-241 } & 800 & \\ \text { U-233 } & 56,000 & \end{array}$




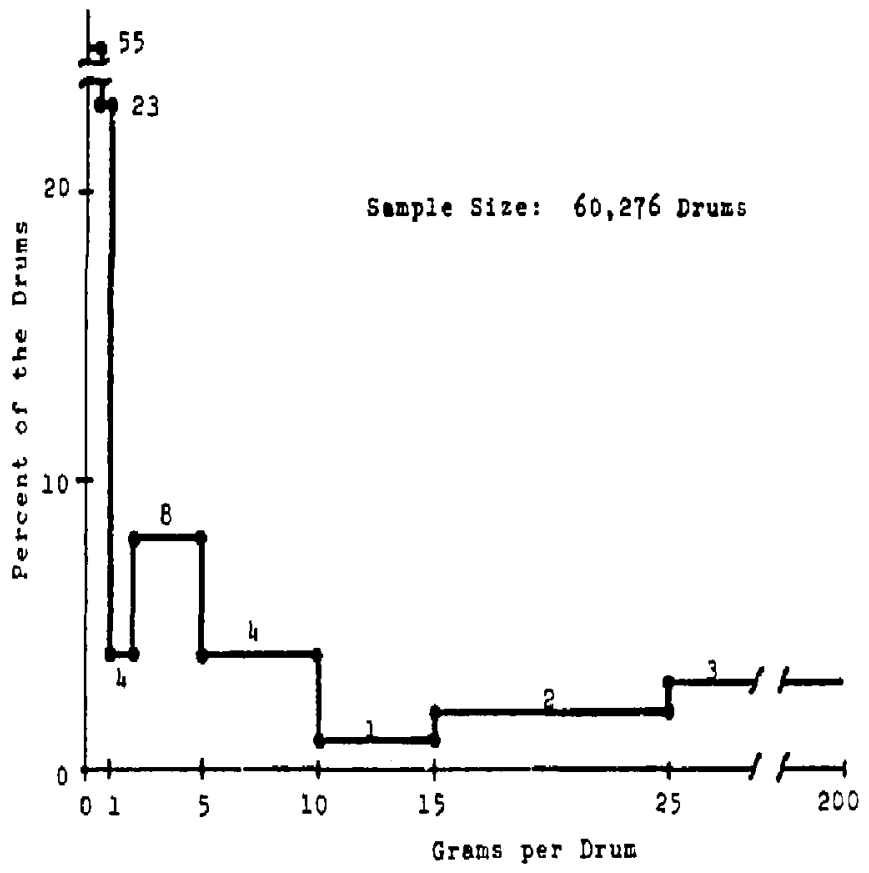

FIGURE 4-1

HISTOGRAM OF PU CONTENT IN DRUMS STORED AT IDAHO FROM SEPTEMBER I, 1977, TO DECEMBER 31, $1977^{68}$ 


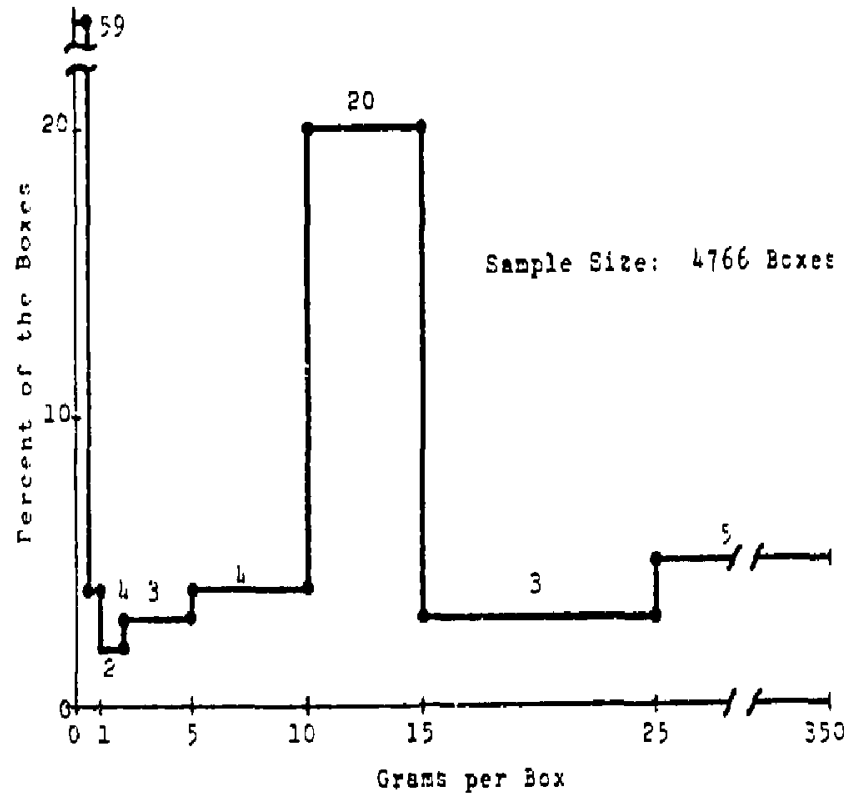

FIGURE 4-2

HISTOGRAM OF PU CONTENT IN BOXES STORED AT IDAHO

FROM SEPTEMBER I, 1971, TO DECEMBER 31, $1977^{68}$ 
are histograms showing the plutonium content of containers stared af ldaho. Figure 4-3 shows the waste generated by Savannah River between July 1, 1974, and June 31, 1977, in their weapon and heat source plutonium activities. The 255 cubic feet of waste containing over 13,000 grams of Pu-238 that was shipped from Mound Labs and Los Alomos is not included. On the overage, o 208-liter drum of this waste will contain about 9 groms of $\mathrm{Pu}-238$.

\subsubsection{TRU WASTE CONTAMINATION LEVEL}

HANFORD

The packing density of Hanford waste is $80-112 \mathrm{~kg} / \mathrm{m}^{3}$. Room- and linegenerated trosh is composed of about 90 percent by volume combustibles and comprises about 90 percent of the total transuranic waste. BNWL expects to treut liquid wastes from the Life Sciences Laboratory, the sludge produced being only $1-3 \mathrm{~m}^{3}$ per year. Honford disposes of 180-380 liters of oil per year, at least half of which is vacuum pump oil from HEQL. In addition, about 7,800 liters of lard oil has been occumulated. Small equipment from the glove boxes and HEPA filters account for 10 percent of the waste at HEDL and 5 percent of that at BNWL. While the laborotories do not keep track of the exact amount of plutoniurn per drum, BNWL estimated amounts at less than $5 \mathrm{~g}$ (with the exception of druins contoining hot HEPA filters).

\section{LOS ALAMOS}

The volume of waste $c s$ is about 8,000 liters per year, the plutonium content being about $10^{-3}$ to $10^{-4} \mathrm{~g} /$ liter. The uncompocted densities of packoged wastes (os determined from a sorting experiment) are obout $64 \mathrm{~kg} / \mathrm{m}^{3}$ paper and rags, $176 \mathrm{~kg} / \mathrm{m}^{3}$ rubber, $80 \mathrm{~kg} / \mathrm{m}^{3}$ plastics, $512 \mathrm{~kg} / \mathrm{m}^{3}$ glass, and $288 \mathrm{~kg} / \mathrm{m}^{3}$ metal.

\section{MOUND LABORATORY}

The average Pu-238 contamination levels in the wastes were $75 \mathrm{uCi} / \mathrm{g}$ for laboratory wastes in 1/4-liter drums, $30 \mu \mathrm{Ci} / \mathrm{g}$ for laboratory wostes in 208-liter 


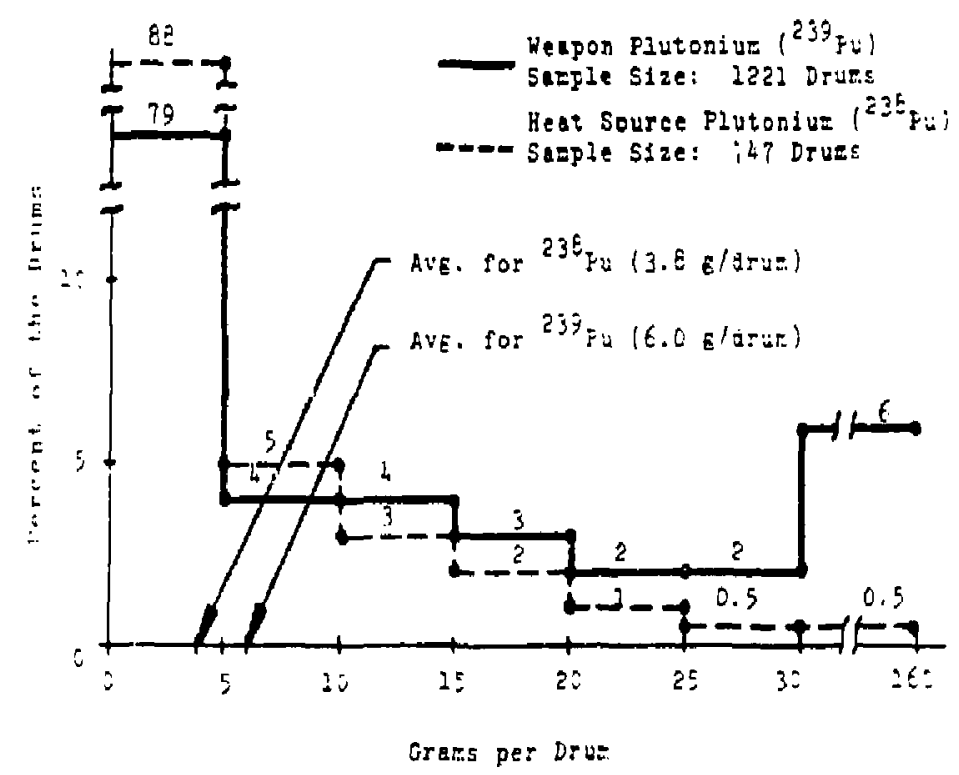

FIGURE 4-3

HISTOCRAMS OF WEAPON AND HEAT SOURCE PLUTONIUM CONTENT IN 55-GALLON DRUMS PFODUCED BY SAVANNAH RIVER FROM JULY I, 1974, TO JUINE 31, $1977^{68}$ 
drums, and $0.75 \mu \mathrm{Ci} / \mathrm{g}$ for the liquid effluent treatment sludge in II4-liter drums.

\section{SAVANNAHRIVER}

Approximately 5 percent of the totul waste volume wos metal in some form. At present, building debris olso comprises obout 5 percent of the total, but this figure is expected to increose in future yeors. The Low Specific Activity wostes ore estimated to overage $0.01 \mathrm{Ci}$ per pockoge, whereas room-generated trosh usually contains less than $0.1 \mathrm{Ci}$ per pockoge and line-generated trash greoter than 0.1 Ci per pockoge.

\subsection{TRANSURANIC WASTE CATEGORIES}

Transuranic waste is categorized in two classes: contact-handled $(\mathrm{CH})$ and remotely handled $(\mathrm{R} H \mathrm{H})$. A qualitative distinction between contact-handled and remotely handled TRU waste is made by DOE: contoct-handled waste emits so little radiation that workers can handle it without extensive shielding; remotely handled waste requires shielding and/or remote handling to protect operating personnel. Therefore, confoct-hondled TRU waste is distinguished from remotely hondled TRU waste on the busis of the surface-dose rote. A criterion endorsed by the DOE designates waste pockages with surfoce-dose rates no higher than $\mathbf{2 0 0}$ millirem per hour (mrem/hr) as contact-handled TRU wnste and those with surface-dose rates higher than $200 \mathrm{mrem} / \mathrm{hr}$ as remotely handled TRU waste. $^{92}$

\subsection{CONTACT-HANOLEO (CH) TRU WASTE}

About 98 percent (by volume) of the TRU waste produced in the DOE complex is clossified as $\mathrm{CH}$ TRU waste.

Contact-hondled TRU waste exists in a wide variety of physical forms, renging from unprocessed general trash and concrete-stobilized sludge to decomminsioned machine tools and glove boxes. Most of the pre-1970 (buried) waste is in 
208-liter drums. Although drums ore still widely used, the present trend is towurd large plywood and metal boxes, which not only cost less than drums but also make mare efficient use of storage volume. At present, about 70 percent of all CH TRU waste is put into boxes, most of it in special plywood boxes, obout $1.2 \mathrm{~m}$ by $1.2 \mathrm{~m}$ by $2.1 \mathrm{~m}$ in outside dimensions, that are covered with a threemillimeter loyer of fiberglass-reinforced polyester and lined with polvvinyl chloride and fiberboard. These boxes are coproved by the U.S. Department of Transportation and are known os DOT-7A containers.

A typical plywood box contains 13 grams of plutoniuin isotopes and produces 0 thermal output of about 0.03 watt; a typical drum contains eight grams of plutonium and produces about 0.02 watt. Surface-dose rates for drums and boxes ore very low: approximately three mrem/hr on the overage for drums and 1.4 $\mathrm{mrem} / \mathrm{hr}$ on the overoge for plywood boxes.

\subsubsection{REMOTEL Y HANDLED (RH) TRU WASTE}

A small fraction (about two percent by volume) of the TRU waste generated by the DOE facilities exceeds the 200 -mrem/hr limit on the surfoce-dose rate of $\mathrm{CH}$ TRU waste. The surfoce-dose rates of almost all packaged RH TRU waste range from a few hundred millirem per hour up to perhaps $100 \mathrm{rem} / \mathrm{hr}$. This waste will be handled by shielded equipment designed especially for the purpose.

\subsection{SUMMARY}

Some of the more important chorocteristics of defense TRU wostes are summarized below.

- Over 98 percent of the TRU waste volume in retrievable storage con be contacthandled.

- The most common woste containers for CH TRU are 208lifer órums and $1.2 \mathrm{~m} \times 1.2 \mathrm{~m} \times 2.1 \mathrm{~m}$ fiberglass-coated plywood boxes, but a wide variety of other sized containers have been used as described in Section 2 . 
- More than half of the drums ond boxes of CH TRU contain less than 0.5 grams of plutonium, but there are o few thot contain 100 groms or more.

- Scrap metal is the most common woste form.

- Eleven percent of the woste by volume contoins 60 percent of the plutonium.

- Paper and rag wastes hove lower-than-overdge plutonium concentrotions.

- First stage sludge may be a significant source of gas gene: ation because of its high water content and high concentrations of plutonium and americium.

The above apply, for the mast part, only to the waste stored of INEL. Also they only describe the waste os it exists todoy. The effects of various processing options are not included. ${ }^{68}$ Table 4-13 presents the istest information for FY 1978. The reader is directed to Appendix $F$ for a more delailed discussion of asgeneroted TRU wostes. 
CONTRACTOR

Ulasfe Type
Cubic

Meters Kilograms
Kilogroms/

Eu. meter

UNIVERSITY OF CALIFORIVIA

LOS ALAMOS SCIENTIFIC LABORATORY

Contaminated Equipment

Decontaminated Debris

Dry Soids

Solid Sludge

$\begin{array}{rrr}64.6 & 54.4 \times 10_{3}^{3} & 842.1 \\ 5.8 & 5.6 \times 10_{3}^{3} & 965.5 \\ 144.6 & 57.6 \times 10_{3}^{3} & 398.3 \\ 214.0 & 356.1 \times 10^{3} & 1664.0\end{array}$

LOVELACE FOUNDATIOH'

Biological Woste

Dry Solids

Not Clossified

$0.2 \quad 21.7$

$1.9 \quad 173.8$

108.5

$0.2 \quad 21.7$

91.5

108.5

MONSAINTO RESEARCH CORPORATIOIN

Decontominated Debris

Dry Solids

Solid Sludge

46.2

70.8

67.9

$17.6 \times 10^{3}$ $57.7 \times 10_{3}^{3}$

381.0

$90.1 \times 10^{3} \quad 1,327.0$

ROCKWELL INTERNATIONAL

Dry Solids

Solid Sludge

$1,009.0$

$386 \times 10^{3}$

383.3

$270.4 \quad 284.0 \times 10^{3} \quad 1,050.3$

UNION CARBIDE NUCLEAR DIVISION

Contaminated Equipment

Decontaminated Debris

Dry Solids

Not Classified

$\begin{array}{rcr}1.5 & 358.3 & 238.0 \\ 0.9 & 263.1 & 292.3 \\ 25.1 & 5.0 \times 10^{3} & 190.2 \\ 0.7 & 136.1 & 194.4\end{array}$

$8.5 \quad 3.6 \times 10^{3} \quad 423.5$

$23.6 \quad 7.2 \times 10^{3} \quad 305.1$

$\begin{array}{lll}578.6 & 150.2 \times 10^{3} & 259.6\end{array}$ 
TABLE 4-13

(CONT.)

CONTRACTOR

Woste Type

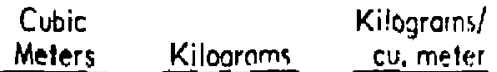

UNITED NUCLEÁR INDUSTRIES

Not Clossified

$19.0 \quad 4.8 \times 10^{3} \quad 252.6$

UNIVERSITY OF CALIFORIIIA

LAWRENCE LIVEPIMORE L.ABORATOPY

Contaminated Equipment

Dry Solids

Not Classified

$\begin{array}{ccc}1.1 & 250.4 & 227.6 \\ 10.1 & 3.4 \times 10^{3} & 336.6 \\ 15.1 & 7.9 \times 10^{3} & 523.2\end{array}$

ARGOINNE NATIOINAL LABORATORY

Dry Solids

$102.8 \quad 26.8 \times 10^{3} \quad 260.7$

BATTELLE MEMORIAL INSTITUTE

Contominated Equipment

$\begin{array}{lll}1.8 & 648.6 & 360.3\end{array}$

EG\&G IDAHO, IIC.

Dry Solids

$3.8 \times 10^{-3} \quad 2.3$

605.3

WESTINGHOUSE HANFORD CO.

Contominated Equipment

Solid Sludge

Not Classified

$13.1 \quad 453.6 \quad 34.6$

$18.7 \quad 28.4 \times 10^{3} \quad 1,518.7$

$\begin{array}{lll}32.3 & 14.7 \times 10^{3} & 455.1\end{array}$

E.I. DUPONT DE NEMOUT.

Contaminoted Equipment

Dry Solids

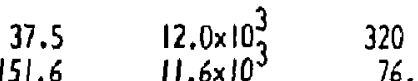




\subsection{POTENTIAL TREATMENT TECHNOLOGY FOR GENERATED TRU WASTE}

The TRU waste problem is being resolved by considering fechnological. economic, institutional. sociol. environmental and sofety aspects. A review is presented of the technical olternatives which are ovoilable and on which economic. environmental. and sofety evaluations can be mode. The purpose of the section is to summorize the technologies avoiloble for potenticl treatment of TRU wostes arising from commercial and DOE operations. Appendix $K$ provides additional information on various technologies ovalable for TRU vicste treot. ment.

TRU wostes can be treoled and pockoged to accomplish several purposes:

- To reduce the vclume of waste required for storcge and disposol

- To increase the marain of safety associated with hondling and storing of wastes

- To recaver tronsuranic elements las discussed in Appendix () ). and

- To reduce the mobility of the wastes during prolonged storage and final geologic disposol

Generol treotment of TRU wostes is shoun in Figure 51 The selection of treatments of, and fingl solidified forms for woste go hond in hand becouse of numerous synergistic factors. Because of the broco scope of TRU waste treatment; only volume reduction and decontamination technologies will be discussed in this section Section 60 discusses immobilization technology. Transuranic $m_{4}{ }^{+}$erial recovery and non-destructive assay are discussed in Appendices ti and l. respectively.

For purposes of this section treatment technology for wastes will be discusset according to types of waste and independenlly of the radioactivity content. The technology in general is the some for any level of radionctivity. However, o high 


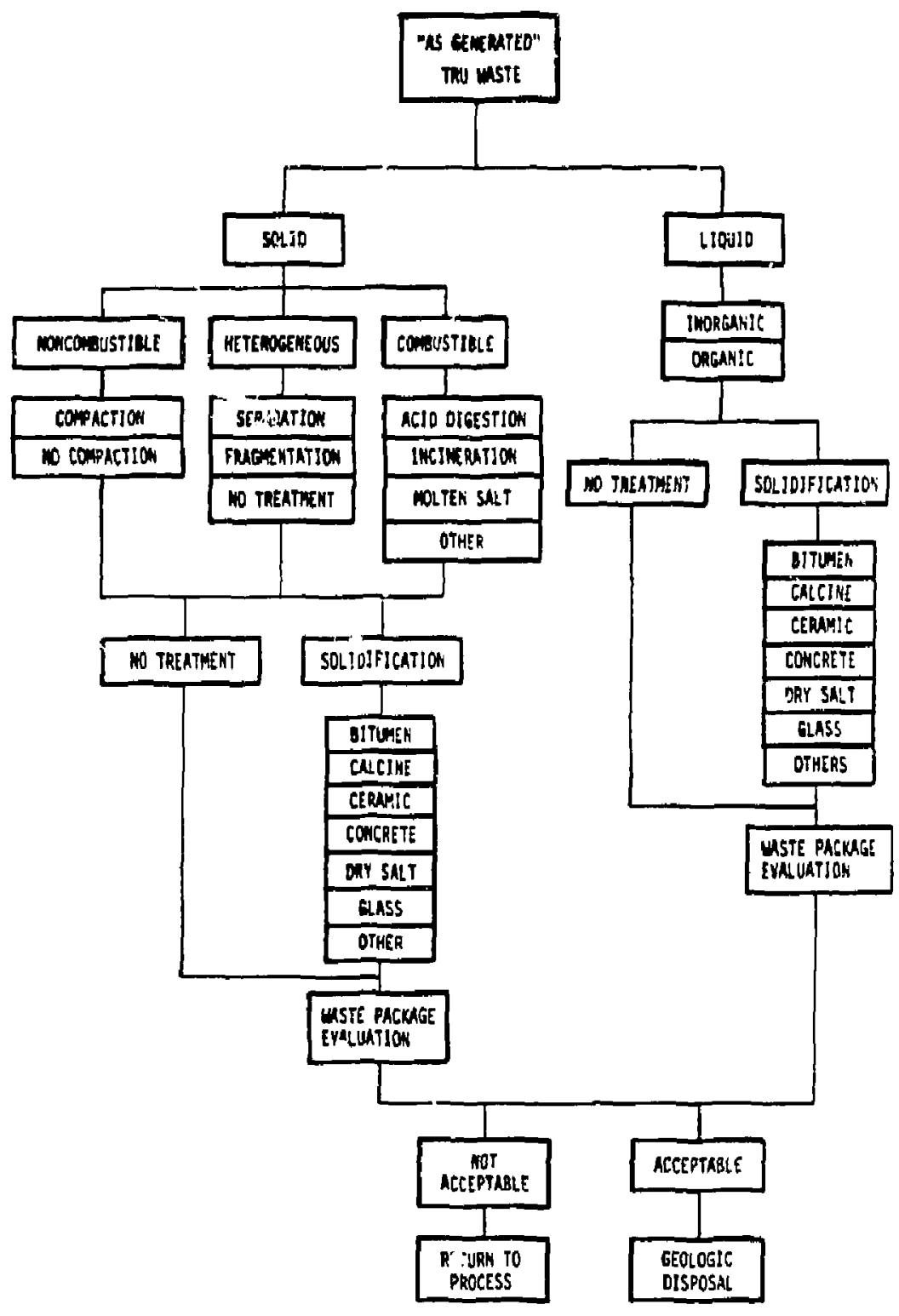

FIGURE 5-1

TREATMENT OPTIONS FOR "AS GENERATED" TRU WASTE 
content of beta-gammo rodioactivity requires special shielding for remote operation of equipment.

\section{I SOUR.CES AND CHARACTERISTICS OF NON.HICH. LEVEL TRU WASTES}

For the purpose of discussing treatment technologies. TRU wastes will be grouped occording to the broad generic cctegories lisfed below:

- Generul trosh

Combustible and noncombustible trash which inclures such rnaterials os cellulosics. plastics, rubbers. HEPA filters. metal and glass items. hand tools. miscellonenus consiruction and insulation materials. etc.

- Discarded equipmierit

Failed equipment and major items from: facility nondification or renovation.

- iNet wastes

Aqueous solutions and slurries: ion exchange resins: filtering aids and sludgesi arganic liquids such os lutricating ails. greases. ano organic solvents.

The quontities and charncter istics of these uostes vory oppreciably from focility to facility, ever, within comparable sections of the fuel cycle. depending laraelv on the maintenance and operational philosophy used of eoch site.

In general. wastes can be identified and treated as shown in Figlre 5-I. Each cotegor y of waste can be processed occording to o selected treotment to produce an immobile product which can be disposed of appropriately. T"entment of any primary woste generates additionul waste (secondary wasie) which is similar in characteristic to one of several types of origginal (primary! waste. For example. incinerotion of combustibie wastes praduces. as part of the operation. additional combustible wostes which art also processed. The net result of such a 
treatment is a significant reduction in the volume for disposal even after treating (recycling) secondary wastes. Accordingly, becouse of the smaller volume, considerable economy in the cost of disposal results.

\subsection{TECHNOLOGIES FOR GENERAL TRASH ${ }^{54}$}

General trash consists of many materials being discorded from a facility. It contains both combustible and noncombustible materials.

Combustible solids consist of a large variety of items such os paper, rags, plastic sheeting, protective clothing, gloves, rubber shoes, wood, filter cartridges, etc., as well as some partially combustible items such os HEPA (high-efficiency particulate air) filters encased in wooden fromes. The octual constituents in combustible waste vory depending on the location of operations generoting the wastes. For example, wastes generated outside of a glove box include primarily cellulosic materials (i.e., paper, cotton clothing and rags, etc.). Wostes generated inside glove boxes, on the other hand, contain primorily rubber or plastic moterials because cellulosic materiols are generally excluded from glove box installations. Typicol compositions used for development purposes are $20-50 \mathrm{wt} \%$ cellulosics, $10-40 \mathrm{wt} \%$ rubbers and $20-40 \mathrm{wt} \%$ plostics. These wastes vory widely between facilities but may be cotegorized on the basis of origin: laboratory, line or process and construction.

The noncombustible froction consists typically of metal, glassware, construction and insulation materials (concrete, graphite, etc.), metal-encosed HEPA filters, small discarded equipment, tools, metal filters, and other mechanical devices.

General trash can be treated for several purposes:

- Ta segregate combustibles from noncombustibles

- To reduce the chemical reoctivity of the wastes

- To reduce the volume 
- To recover quantities of TRU material, and

- To decontaminate it by removing rodioactivity

The treatment technologies either ovailable or being developed for generol trosh are shown in Figure 5-2.

\subsubsection{PRETREATMENT (SORTING, SHREDDING, CLASSFICATIOIN)}

General trash olmost always consists of both combustible and noncombustible moterials, and pretreatment operotions are often required prior to further treatments. Pretreatment of waste, i.e., the physical or chemical processes necessary to prepore woste for primory treotment ond/or disposal, includes operations such as assoy, sorting, shredding and classification. In generol, the technologies for pretreatment operations are readily available and have been used at DOE and/or commercial sites.

\subsubsection{SORTING}

Hand sorting is the simplest method of segregating mixed wastes into constituents which are omenable to treatment by a particular technology. Although this moy best be done of point of origin, the wastes are often sarted ofter collection as part of a waste treatment operation. The categories into which the wastes ore sorted will be determined by whotever primary treotment options are selected and used. Hand sorting is used to assure separation of combustiole from noncombustible materials; it is also used to identify and remove hazordous moterials (e.g., pyrophoric or explosive substances) in the waste treatment area. Sorting of plutonium contominated wostes occording to the plutonium content has been used for a number of years ot DOE operating sites.

Typically it is desirable to segregate solid wastes into combustible and noncombustible fractions. Following suitable preireatment, combustible wostes can be combusted, decontaminated, compacted or packaged. Similarly, noncombustibles can be decontaminated, compacted, melt-cost, dissolved, and/or packaged. 


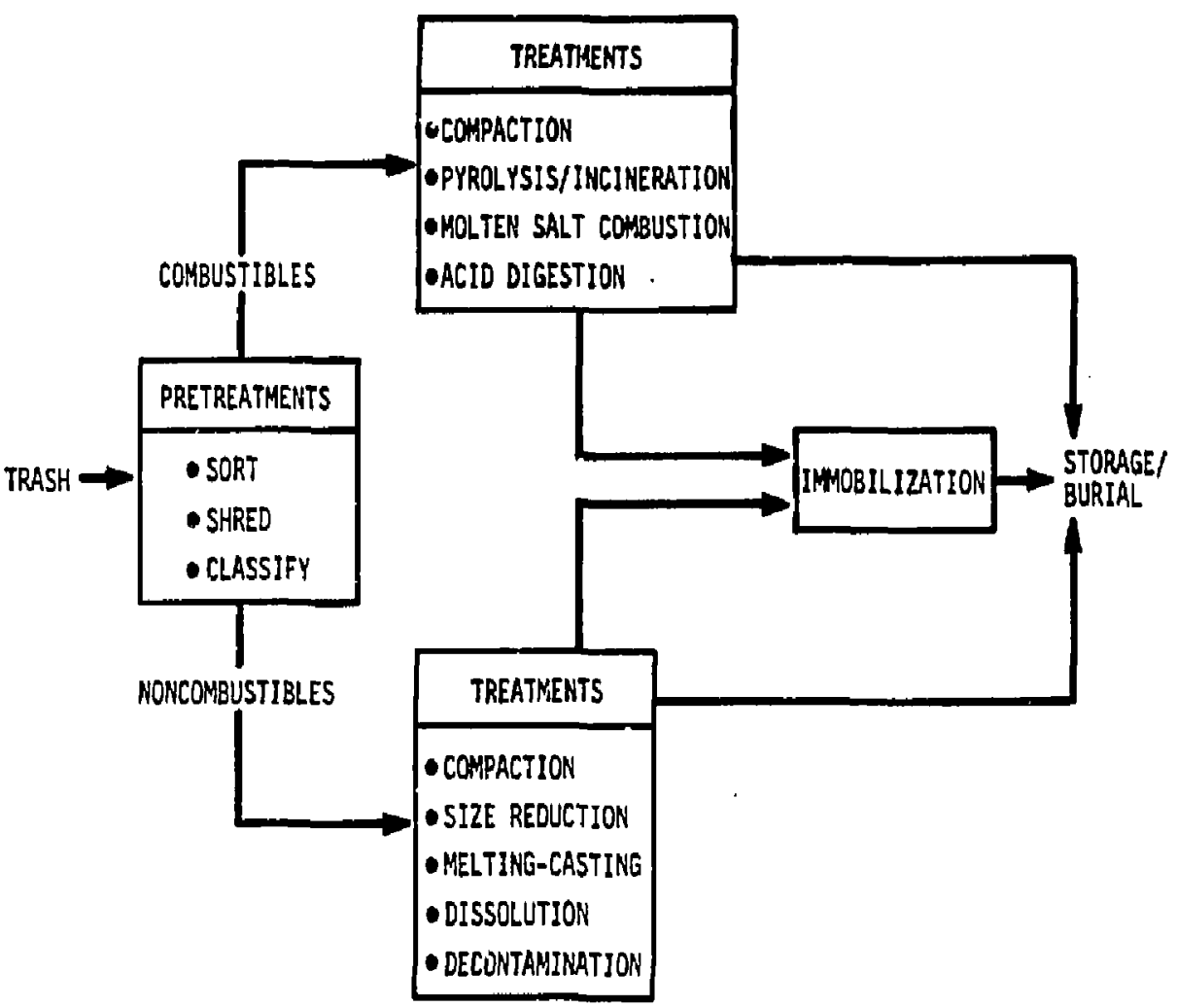

FIGURE 5-2

VOLUME REDUCTION OF GENERAL TRASH 
Decontamination and melt-casting are discussed under technologies for treatment of discarded equipment. Dissolution in salis is being developed as an extension of the molten salt combustion technology discussed later under combustion. Alternatively, noncombustibles are sometimes incorporated directly into cement and other agents for immobilization.

\subsubsection{5HREDDING}

Shredding is used on potentially zombustible waste materials to produce small pieces for subsequent processing or disposal. The principol types of shredding equipment are knife cutters, hammerrrills, and voriations or combinations thereof.

Commercially ovailable knife cutters used for size reduction ore grouped into three brood cotegories:

- Fly knives mounted tangentiolly on a rotor to work against stotiongry bed knives

- Finger knives mounted axiolly on a rotor to work agoinst stotionary anvils

- Finger knives mounted axially on tvio counter-rotating rotors

Fly knite cutters hove the disadvontage of being susceptible to damage from. tramp metol in the feed. The knives must be shorpened or replaced periodically.

Shredders of the counter-rototing rotor type are being tested at HELL and Rocky Flats for application to TRU contominated combustible wastes. It is noted that dust explosions hove proven to be o problem in shredders and the potential for such explosions should be considered in any system design.

Hammermills consist of pivoted or rigidly mounted hammers on a vertical or horizontal shaft or rotor. The hammers moy be rectangular or chisel shaped. Crushing or shredding takes place by impoct between the hommers and a breaker plate. These shredders are more effective on brittle and noncombustible wastes. They are less useful for shredding plostics becouse of the tendency of these 
materials to bind the hammers. SRP is planning to utilize a hammermill to process vo:ious TRU woste of its TRU Woste Focility, ${ }^{47}$

\subsubsection{CLASSIFICATIUN}

Classification by air or inert gases (pneumatic sorting) can be used following shredding to segregate woste materials by density difference. The principal application is in the separation of combustible (law-density) fron, noncombustible (high density) wostes.

Rocky Flats has a pneumotic classification system under development in support of combustion process demonstration plants. Closed system preumatic sorting has not been demonstrated for handling nuclear process wastes. However, air classification is used for separating municipal refuse into noncombustibles (glass, metal, etc.) and combustibles (poper, plastics, etc.), the latter then being used as a source of energy. Other than radioactivity and the smaller operating scole of the treatment focility, no major differences exist between nuclear fuel cycle wostes and municipal wastes.

\subsubsection{COMPACTION}

Compaction is the simplest process for reducing the volume of trosh for disposal. Compactors are widely used in the nuclear industry for reducing the volumes of general trash and combustible wastes. The technology is well established for commercial applicotion and is discussed in detail in Appendix K. In compaction the waste is compressed inside of a contoiner which then is closed. Some wastes are also amenable to $\mathrm{a}$ baling operation in which the wastes are compressed and then banded so that they cannot expand; the bale can be subsequently packaged for further disposition.

A typical dry waste compactor consists of a hydraulic system with a ram operating vertically downward, a contoured support plate, frame and safety enclosure with a loading table, vent, and filter system and associated fan, gouges and controls. 
A special application combining shredding and baling has been tested of the Rocky Flats Plonts. The shredder-boler system shreds and compocts combustible, compressible wastes. Combustible wastes which ore callected outside the dryboxes are placed in 208-liter drums. These drums are then counted using sodium iodide defectors for measuring quontities of plufonium. All drums containing nondetectoble amounts of plutonium are sent to the shredding operotion. 54

\section{2. $\quad$ COMBUSTION TECHNOLOGIES}

Combustion treatments under development for radiooctive wastes include incineration, pyrolysis, acid digestion, and molten salt combustion as indicated in Table 5-1. Incineration involves the burning of combustible materials in air or in an oxygen-rich atmosphere. Pyrolysis implies burning in ap oxygen-deficient atmosphere which provides gasification of part of the waste material. Acid digestion involves oxidation of moterials by nitric acid in a concentrated sulfuric acid media. Molten salt combustion involves air oxidstion of combustible materials in a nolten salt environment. These technslogies nave evalved from numerous combustion system design and operating experienc: some of which is given in Toble 5-2.

The application of combustion or incineration to the treatment of combustible solids requires the coupling of several processes or unit opercitions into a total waste treatment system which includes feeding, incineration, off-gas treatment and ash/residue packoging and/or immobilization. Some waste materials such as chlorinated rubbers or plastics pose more stringent requirements on the design becouse of the generation of soot and because of corrosion by hydrochloric acid vopor produced during combustion. Special design feotures are required to contain the radioactivity and to provide adequate personnel protection.

The necessary conditions for achieving complete combustion in any incinerator ore;

- Adequate residence time

- Adequate temperature (to promote complete combustion) 
TABLE 5-

BRIEF DESCRIPTION OF CANDIDATE SOLID WASTE PRCCESSING CONCEPTS

\begin{tabular}{|c|c|c|c|}
\hline CONCEPT & PURPOSE & BRIEF DESCRIPTION & PRODUCTS FROM PRIMARY PROCESS" \\
\hline SORTING & $\begin{array}{l}\text { Clossify mixed solid woste } \\
\text { in occordonce with pro- } \\
\text { cessing requirement. }\end{array}$ & $\begin{array}{l}\text { Momal physical clossification of } \\
\text { mixed solid wost fs. }\end{array}$ & $\begin{array}{l}\text { (1) Solid wasie suitoble for treot- } \\
\text { (2) Sont by ceitid woste unsuiton processes. } \\
\text { ireaiment by combustion processes. }\end{array}$ \\
\hline COMPACTION & $\begin{array}{l}\text { Increose bulk density of } \\
\text { solid woste to rectuce } \\
\text { volume. }\end{array}$ & Mechomical compression & High bulk dernity solid woste \\
\hline $\begin{array}{l}\text { CONVENTIONAL } \\
\text { INCNERATION }\end{array}$ & $\begin{array}{l}\text { Reduce volume of combustible } \\
\text { solid woste ond convert to } \\
\text { inert residue. }\end{array}$ & Conventionol combustion & $\begin{array}{l}\text { (1) Condersible and nomoondentible } \\
\text { (2) Sostid residue. }\end{array}$ \\
\hline $\begin{array}{l}\text { CONTINUYOUS } \\
\text { PYROLYSIS }\end{array}$ & $\begin{array}{l}\text { Seporate more volatile } \\
\text { cormponents ond thereby } \\
\text { reduce volume of combustible } \\
\text { solid waste. }\end{array}$ & $\begin{array}{l}\text { Solid waste heated in oxyger } \\
\text { telicient almosphere te thive } \\
\text { off more volotile components: } \\
\text { combustihle ollquses burned in } \\
\text { sepornte chombers }\end{array}$ & $\begin{array}{l}\text { (1) Condersible and noncondenatble } \\
\text { (2) Soseous products of comt -tid resindue. }\end{array}$ \\
\hline $\begin{array}{l}\text { PRESSUFIZED } \\
\text { AGUEOUS } \\
\text { COMBUSTION }\end{array}$ & $\begin{array}{l}\text { Reduce volume of combustible } \\
\text { solid waste and convert to } \\
\text { inert residue }\end{array}$ & $\begin{array}{l}\text { Batch process in which waste is } \\
\text { reacted with oxyoer under water in } \\
\text { o pressure vessel. (Coutd be } \\
\text { designed for contimous operation }\end{array}$ & $\begin{array}{l}\text { (1) Noncondensible goweous products } \\
\text { of combustion. } \\
\text { (2) Liquid woste comilioning solutile } \\
\text { ond condensible combustion } \\
\text { (3) Srowhels. } \\
\text { solid residur. }\end{array}$ \\
\hline $\begin{array}{l}\text { PRESSURIZED } \\
\text { OXYGEN } \\
\text { COMBUSTION }\end{array}$ & $\begin{array}{l}\text { Reduce volume of combustible } \\
\text { Solid waste mo convert to } \\
\text { inert residue. }\end{array}$ & $\begin{array}{l}\text { Fufch processs in which waste is } \\
\text { burned in oxparn-rich ofmosphere } \\
\text { in presseme vessrl. }\end{array}$ & $\begin{array}{l}\text { (1) Condersibte ond moncondensible } \\
\text { (2) Solit residue. }\end{array}$ \\
\hline $\begin{array}{l}\text { MOLTEN SALT } \\
\text { DI JPNING }\end{array}$ & $\begin{array}{l}\text { Reduce volume of combasstible } \\
\text { solid waste nnd convert in } \\
\text { ipert residue. }\end{array}$ & $\begin{array}{l}\text { Thitch process in which woste is } \\
\text { twirned with oxyoen uncter irmeri } \\
\text { molten solf. }\end{array}$ & $\begin{array}{l}\text { (1) Condensible ond noncondensible } \\
\text { (2) insert funed solts of combustion. } \\
\text { (3) Solid resiche. }\end{array}$ \\
\hline
\end{tabular}

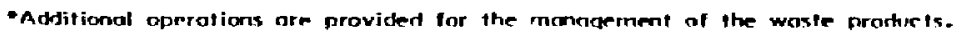


TABLE $5-2$

INCINERATORS USEU FOR COMBUSTION OF RADIOACTIVE SOLIO WASTES ${ }^{10}$

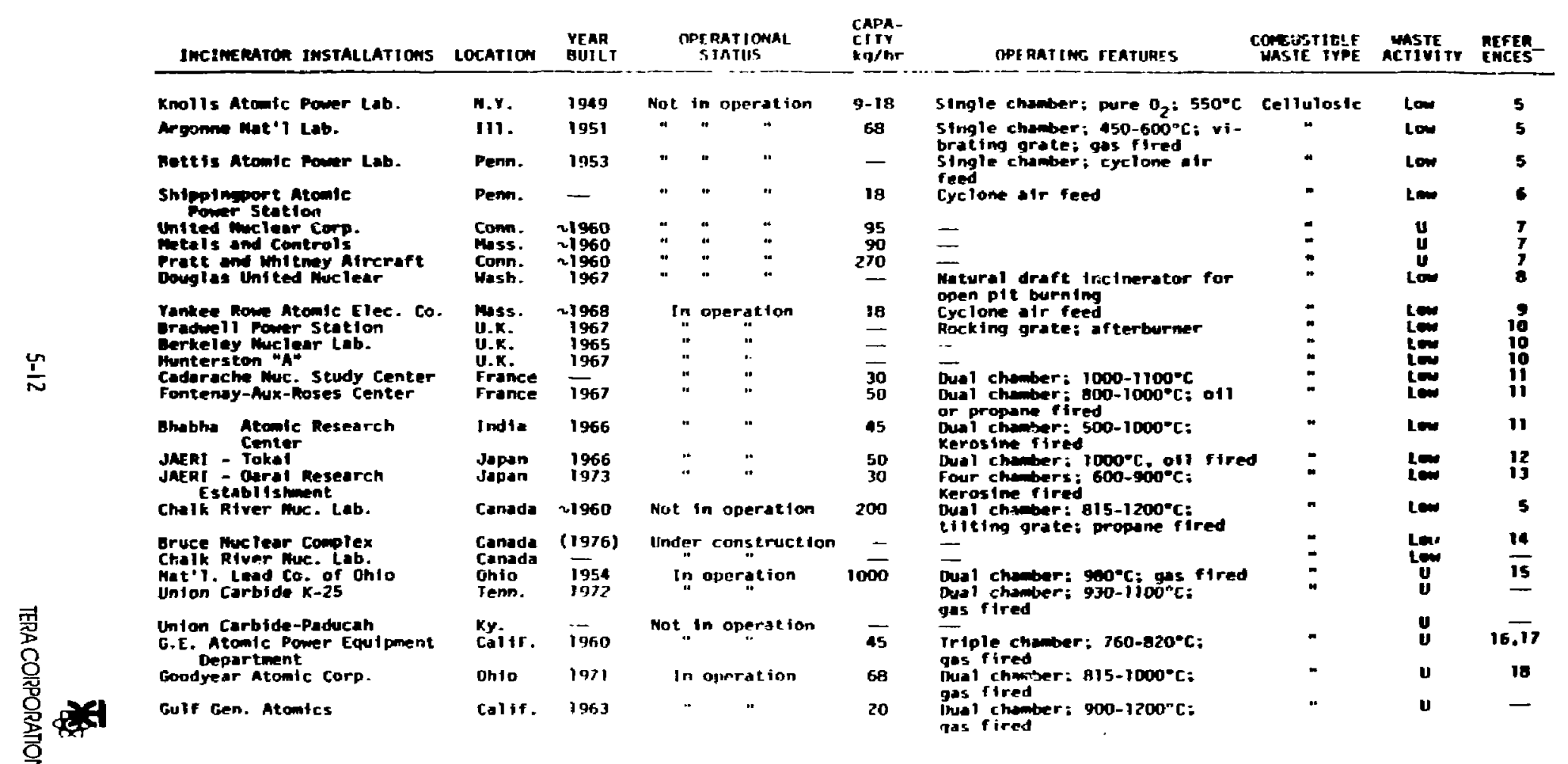




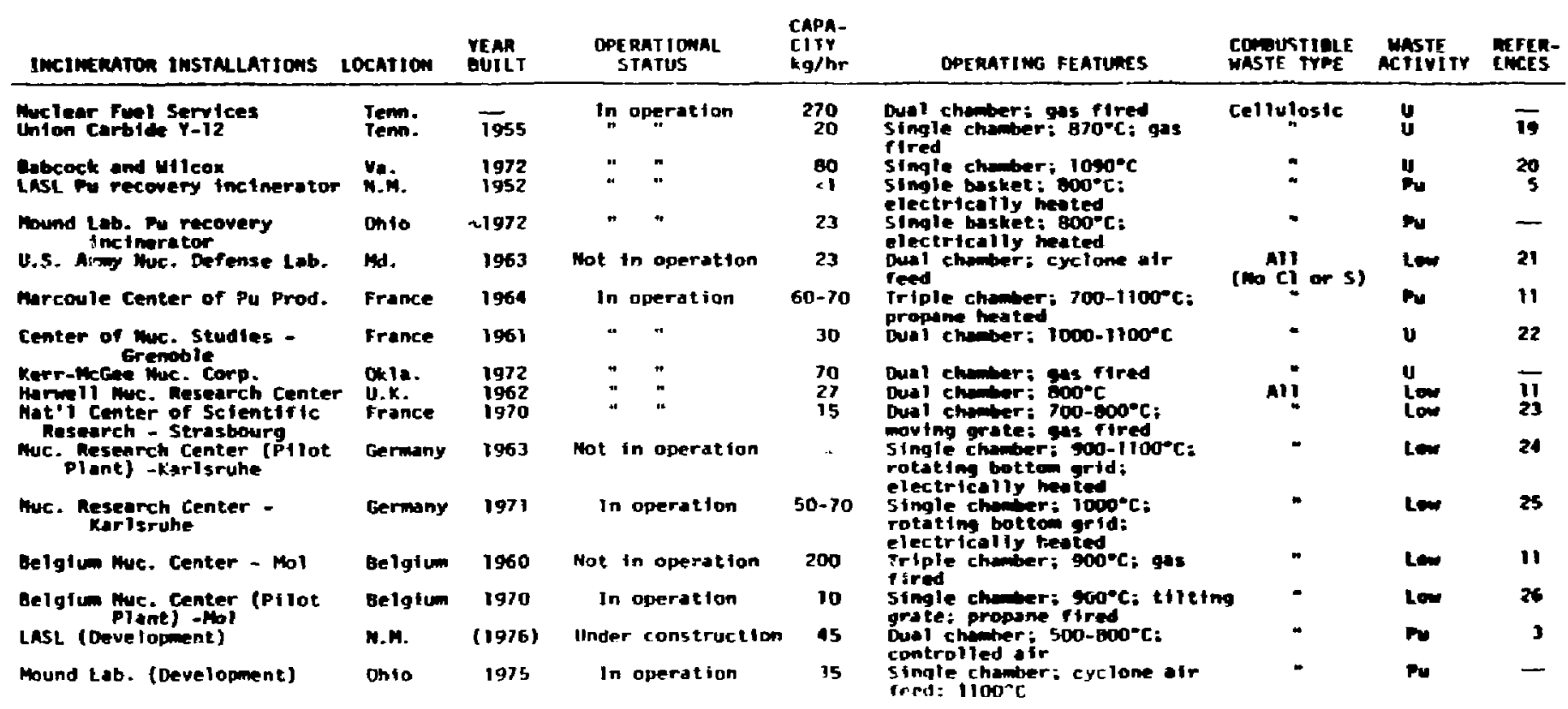


TABHL 5-L

(CONT.)

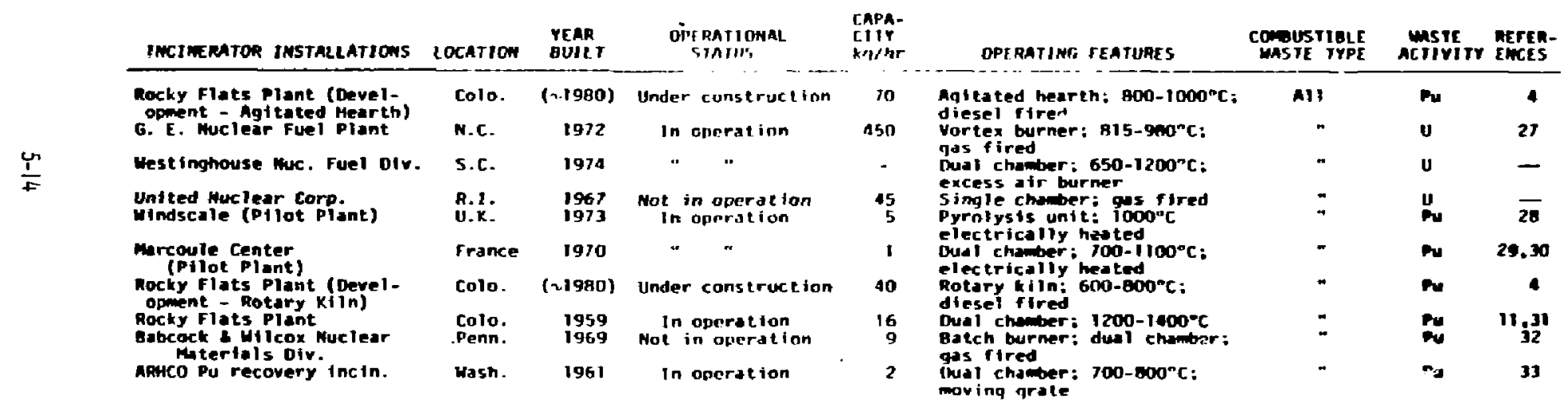

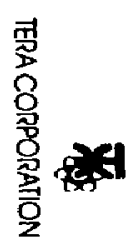


- Turbulence (to promote good mixing)

- Sufficient oxygen

Problem areos in the past hove included spolling and warping of construction materiols: incomplete combustion clogging fires outside the furnace chamber inadequate ash handling and off gos cleanup systems and corrosion Experier.ce with rodiaactive incinerator systems hos shown a need for improved performance. Toble $5-3$ presents a brief list of technologies which ore or have been under development recently by DOE.

The following discussion covers the distinguisning features of comijustion devices in use or being developed. A more detailed discussion of the various technologie's is provideo in Appencix K.

\subsubsection{CONTFIGLLED AIR INCINEPATOR}

A controlled air incinerotor hos been installed at LASL and is undergoing testing. Controlled air systems use rrultiple-chamber burning to ochieve comiplete combustion of solid waste. Charges of waste enter the first chamber where they bum in the presence of substoichiometric quantities of air at about $500-800^{\circ} \mathrm{C}$. The products of portiol oxidation and volatilizotion flow into o second heated combustion chamber where excess air provides complete combustion at 1000 $1500^{\circ} \mathrm{C}$. This mode of operotion produces a nonturbulent cambustion environment in the first chamber and minimizes the entroinment of fly osh.

\subsubsection{CYCLONE INCINERATOP.}

Older single-chamber incinerators supply excess air in addition to that required for combustion. The use of surplus air results in lower burning temperafures and more fly ash carryover into the combustion gases than are obtained in contralled air incinerators. At Mound Laboratory, an advanced design of an excess air cyclone incinerator is being demonstroted in a cold pilot plant. A distinctive feature of the unit is the combustion of wastes directly in the drum by using the drum as a combustion chamber. The gaseaus effluent has shown no detectable radioactivity after filtration through a deep bed fiber filter. This technology is ovailable for commercial application. 
TAIHLI. S-I

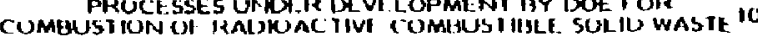

\begin{tabular}{c} 
Process \\
\hline Acid \\
Oigestion \\
Agllored \\
Heorth \\
Incineration \\
Centrolled \\
Air
\end{tabular}

Contralled

Pyrolysis

Crelone

Fluldized-thed
Incineration

Molren Solt

Ratory Kiln

Incineration
Proces:

Design

Sulfuric-nitric ocid oxidation of
waste af $230^{\circ} \mathrm{C}$; liquid system

Stationory circulor heosth with

robble orrm rotating per icdically

to disctiors owh. Primot chamber

Uual combustion chomber; pr irrany chamber $500-600^{\circ} \mathrm{C}$; seccondary

Limiled oir combustion in a verti-

cal retor distiHs volatile moter -

iads which bum in a second git:-

rich zane: primor zane 6100

Verfical combust ion chomber t air swirls and cools the mill. Temperolure 1,100 $\mathrm{C}$.

Pretheated gas mixture, fluidizes waste in $\mathrm{Na}_{2} \mathrm{CO}$ solt bed; $\mathrm{pr} \mathrm{i}$ -

mory bed $356.600^{\circ} \mathrm{C}_{i}$ in sits

meutralization of $\mathbf{H K i}$.

Air axidation in molten $\mathrm{NH}_{2} \mathrm{CO}_{3}$

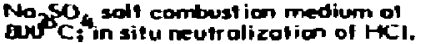

Inclined rotating hor izontol cylinder; ralory heorih increoses oxidotion by exposing rew wastes primory chomber $1,000^{\circ} \mathrm{C}$
Volume
Pechution
Pactor:

$30-50$

30.50

30.54

30.50

$30-50$

20-40

$30-50$

30.50
Product

Non-corntbustible sulf utes and oxides

Non-combustible

refroctory oxide

Non-combuslible, highly

refroctory axide

Non-cornbuntitive

refroc lory oxide

Non-combustible, highly

Non-combust ible

refrector y oxide

Non-combuntibte saltis lewerhed

\section{Non-combust ibte}

Assurnes the same mixed waste tor each process and initial processing only fi.e., no final canversion of residue nor ine process itseli).

-. Pal currently lunded; est imaled ither yeors needed to develop procest for conmerciol applicalion. 


\subsubsection{AGITATED HEAP.TH INCINERATOR}

An agitoted heorth incineralor is being fabricated for combustion of low-level contaminated wastes at Rocky Flats. The ogitated heorth incinerator uses the motion of the grate to move waste material and constantly expose new unburned material for combustion. Combustibles ore charged by a ram feeder onto a circular hearth and moved through the incinerator by rotating rabhle arms. The chamber is heoted to $600-8000^{\circ} \mathrm{C}$ by oil-fired burners. Ash is dischorged on o batch bosis tollowing completion of combustion. Cases and fly osh are further combusted in an ofterburner at $1000^{\circ} \mathrm{C}$.

\subsubsection{FLUIDIZED-BEU INCHERATCK}

Fluidized bed incinerotion has been demonstroted at Rocky Flats in a cold pilot plant, now used to burn TRU nonline-genercted solid and liquid wastes. In the fluid bed incinerator the shredded wastes are introduced into o vertical, fluidized bed of inert material of $525-625^{\circ} \mathrm{C}$. The highly ogitated fluidized systen improves mixing and combustion efficiency. It also provides improved tempero. ture control aue to the heot dissipotion properties provided by the fluidized iner: material. Use of pelletized sodium carbonale as the inert bed material provides odditional benefits through neutrolization of acidic combustion procucts, such os $\mathrm{HCl}$, thus permitting use of less expensive construction moterials in the incinerotor and off-gos ireatment system.

\subsubsection{NOVIVG GELT INCIINERATOK}

A moving belt incinerator is being used at Hanford for plutonium recovery froml scrop. Combustitile wastes are burneo of $700-800^{\circ} \mathrm{C}$ by possing them through an electrically-heoted, horizontal cylindrical furnone on a noving woven wire belt. Volatile components ond fly ash are burned in a secondary fubular furnace surmaunting the primary furnoce. 


\subsubsection{PYROLYSIS-INCINERATOF,}

The pyrolysis-incinerator or vertical refort process has been demonstrated by Pocific Northwest Loboratory with simulaked, nonrodiooctive woste. Develop. ment for use on radioactive woste is not being conducted at this time. In a pyrolysis-incinerator, combustible .raterial is thermolly decomposec in an oxygern-deficient afwosphere to yield a volatile gos which is subsequently combined with excess oir and burned in o secondory combustion chamber. A pyrolysis-incinerator depends on accurate control of the amount of air fed to the burning chambers for efficient operation.

\subsubsection{ROTAPY KILN IN:CINEPATOR}

A rotary kiln demanstration plent is now teing Jesıgned to process wirstes at the Focky Flats Plant. The primary combustion chamber is a tilted horizontal cylinder that ratates on its longifudinal axis to provide o tumbling action for inproved combustion efficiency. Combustible solid woste. HEPA filters. ion exchange resins and liquid wostes from onalytical loborotories will be burned or calcined in the diesel-fuel fired rotory kiln at $600-800^{\circ} \mathrm{C}$, Git-gases poss through an afterburner operatec o! $1000^{\circ} \mathrm{C}$.

\subsubsection{VOFTEX NNCINEFATOR}

General Electric at Wilmington. North Corolina, has hod a vortex or suspenced burning type incinerolor in service on uronium fuel fobricotion wostes since 1972. Cambust ible wostes ore shredded and blown tangentially olong with excess air into a cylindrical thomber. Centrifugal forces provide turbulence required for complete oxidation and to cssist in separation of the ash from the chamber.

\subsubsection{ACID DICESTION}

Engineering feasibility of an xid digestion process hos been demonstrated by HEDL. In the acid digestion process, shredded cambustible wastes are added to a simmering $\left(250^{\circ} \mathrm{C}\right)$ concentrated sulfuric ocid solution which carbonizes the woste. Nitric acid is added to the carbonaceous mixture to vamplete the 
oxidation to carbon dioxide. A shallow tray is used as the principal design feoture to keep the system sofe from nucleor criticality while handling runti. ties of fissionable materials. Solids which accumulate in the system are removed during operation by periodic transfer of a portion of the acid slurry to a separate evaporator pot, from which sulfuric acid is evoporoted at $350^{\circ} \mathrm{C}$ and returned to the digester for reuse. The resulting dry powder is compo: ad primarily of inorganic sulfoles and oxides and is thermally stable when heated in oir.

Plutonium (including refractory plutonium oxide) is converted to a sulfote precipitate during ocid digestion and remains with the process residue. Following evaporation of sulfuric ocid trom the residue. the plutonium can be dissolved from the residue by leaching with dilute nitric ocit. The nitric and sulfuric ocids in the off-gas can be recovered and recycled for reuse.

\subsubsection{NOLTEN SALT COMAUSTION}

The molten salt combustion process has been investigated at Atomics Internotional since 1969. The process has been tested for the destruction of chlorincted liquid wasies, destruction of toxic sind lethal chemicals, and destruction of other combustible moterials. Combustion has been demonstrated on a bench-scale with plutonium and beta-gamma contaminated wastes and on pilot plant scole with uncontaminated waste. The molten salt combustion process uses a molten mixture of sodium carbonate and sodium sulfate salts, contained in an oluminabrick-lined steel furnace, os a medium for air oxidation of combustible wastes. Shredded combustible waste materiols are fed with oir (100 percent excess) beneath the surfoce of the molten salt: which is mainfoined at $800-8.50^{\circ} \mathrm{C}$ Ly the com? istion process. Combustion residues occumulate in the salt. A portion of salt is removed periodically from the furnace and cast directly into storage drums. Alternatively: the melt-ash mixiure can be processed to recover sodium carbonate and sodium sulfate for recycle to the combustor: and to produce an ash and sodium chloride fraction for storage. Plutonium is readily dissolved from the ash with nitric or hydrochloric ocid. 


\subsubsection{SLAGGING PYROLYSIS 77}

The incinerator would be a vertical furnace composed of a gosifier and a secondary conbustion chamber. Solid waste material would be fed into o happer ot the top and introduced into the gasifier through a sealed air lock. Solids from the off-gas treatment system would olso be introduced in this manner. The gasifier would hove three vertical zones: the drying zone. the pyrolysis zone, and the combustion zone. The combustion zone, operating of about $1650^{\circ} \mathrm{C}$. would be refractory lined and could be mounted on rails and provided with flanges to facilitate removal for rebricking. In the molten slag partion of the gasifier. water would flow through a cooling jacket around the slag to prevent deterioration of the metal walls of the vessel. The slog would be cooled considerobly by this woter. Therefore, fuel oil would be burned above the slag surface to prevent further loss of heof by rodiotion. Excess air and fuel oil would be added there to ensure complete combustion of the waste gas from the gosifier.

Becuuse of the relatively low heat content of the TRU wasle material, it would be necessary to odd supplementary heat to the gusifier to produce a molten slag. This heat would be produced primarily by adding cool and bark to the process feed and by using combustion oir preheated to $1040^{\circ} \mathrm{C}$. Even if most of the supplementary heat were supplied by fuel oil, it would be necessary to add scrite quantity of a bulky solid fuel to increase porosity of the feed and enhance the flow of gases upward through the charge of moterials.

The resultant slog would be poured i:ito molds and moved to a cooling chamber. After cooling, the castings would be removed from their molds and transferred to an assay and inventory station. Any defective costings would be returned to the incinerator feed stream for remelting. From the assay and inventory station, acceptoble castings would be pockaged into steel drums.

\subsubsection{DOE INCINERATOR CONPARISON $14 \%, 150$}

Recent andyses by DOE of various incinerator options have been performed in the development of DOE's Waste Monagement Program. Tables 5-4 through 5-11 present summary tables of these analyses. A more extensive discussion of DOE evaluation, especially oriented towerd TRU Waste at INEL. is presented in Appendix K. 
TABLE $5-4$

CAPSULE DESCKIPIIUNS OH MAJOK COMIUSTIUN PIROLESSE $5^{149}$

Corribustion

Process

Acid Digestian

Controlled Air

Crclone

Incincerator

Fluidized Eled

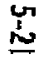

Malten Solt

Comrolled-Ai (Electrie)
Site/Developrnent

Honford Fngineering Develoument Laboratory.

active unil constructed.

Los Alamos Seientific Laborgtory. $45 \mathrm{~kg} / \mathrm{hr}$ unit operational.

monnd Laboratory. $23 \mathrm{~kg} / \mathrm{hr}$ unit for $\mathrm{Pu}$ waste operaled since February 1976.

Hacky Flois.

$92 \mathrm{~kg} / \mathrm{hr}$ unil under construction.

Idaho Notionol Engineering Lobora$45 \mathrm{~kg} / \mathrm{hr}$ unit designed for INEL.

Sovomah River Laboratory.

$0.5 \mathrm{~kg} / \mathrm{hr}$ pillat $1 \mathrm{mit}$ in operation.

$50 \mathrm{~kg} / \mathrm{hr}$ production unit alan.

1502
Description of Combustion Proces

Combustible wostes ore converted io gosecous products acid at $250 \%$ c. Process vielos nonrodionctive gases ond dry salt cake containing thermally stable inorganic sulfates and oxides. Acid goses ore oxidized and recycled to the process.

Combustible wastes go incinerated in starved oir primary chomber at $800^{\circ} \mathrm{C}$. Oxidation of volatile comporents and entrained solits is corrote secondary chomber of $950-1200^{\circ} \mathrm{C}$. A high-energy aquecus off-gas cleoning system is used.

Combust ible and noncombust ible wastes ore procesent batchwise in a steel deum. Air, fed in at lop of the drum, creates a vorten. bustion and cocis the drum wall. Aqueous off-gas cleaning is utilized.

Waste is bumed at $550^{\circ} \mathrm{C}$ in o fluidized bed of sodium corbongte grames sthot provide in sinf neutratization of acidic gases such os Hel. Caidyric afterburning and sintered melof filtration ore utilized in the dry off-pos leaning system.

Combustible wostes and air ore led cantinuously beneath a surfore of molten mixture of alkoti metol corboricles of $100^{\circ} \mathrm{C}$. Ash and ocidic goses ore retained in the meif. Completely dy off-gos system catches

Combust ibte wosses ore pyrolyzed and burned in ssor ved air. A secordory oviner is employed to oxidize rotatice cornbeustion products. An osh dischorge is without

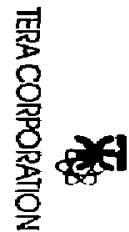


TABLL 5-5

CUMPARISON OF COMBUST HON TECHNOLOGIES: PHETREATMENT 'HA

\begin{tabular}{|c|c|c|c|}
\hline & $\begin{array}{c}\text { 1. } \\
\text { Removal of } \\
\text { incompatible materials }\end{array}$ & $\begin{array}{c}\text { OP E K A T I O N } \\
\text { 2. } \\
\text { Size reduction } \\
\end{array}$ & other \\
\hline Acid Digestion (HEDL) & Mand sort & Double stredding & $\begin{array}{l}\text { Air classification proposed } \\
\text { to separate noncombustibles } \\
\text { froin shredded waste }\end{array}$ \\
\hline $\begin{array}{l}\text { Controlled Air } \\
\text { Incinerator (LASL) }\end{array}$ & $\begin{array}{l}\text { X-ray inspection, hand sort } \\
\text { high-density materials }\end{array}$ & $\begin{array}{l}\text { Optional sturedding of high- } \\
\text { density combeust ibles only }\end{array}$ & \\
\hline $\begin{array}{l}\text { Cyclone incinerotor } \\
\text { (Mound) }\end{array}$ & Not required & Not required & \\
\hline $\begin{array}{l}\text { Fluidized bed Incinerator } \\
\text { (Rocky Flats) }\end{array}$ & $\begin{array}{l}\text { Hond sort to remove metal } \\
\text { scrop }\end{array}$ & Double shredding & $\begin{array}{l}\text { Air elassification to re- } \\
\text { move dooncombustibles from } \\
\text { sturerided waste }\end{array}$ \\
\hline $\begin{array}{l}\text { iMolten Soll Combustion } \\
\text { (Al/HNEL) }\end{array}$ & Hand sort & $\begin{array}{l}\text { Shredder followed by tam- } \\
\text { mermill }\end{array}$ & Transfer to storoge hopper \\
\hline $\begin{array}{l}\text { Electric Controlled Air } \\
\text { (SRL) }\end{array}$ & Hand sort & Shred & Place in poper corton \\
\hline
\end{tabular}

Shred

Place in poper corton 
TABLE 5-6

CUMPAKISON OF COMBUSIIUN TECHNOLOC,IES: FELU SYSTLMS ${ }^{149}$

Acid Digestion (HEDL)
Controlted Air
Incinerator (LASL)
Cyelone Incinerolor
(Mound)
Fluidized Bed Incineralor
(Rocky Flats)
Molyen Sols Combustion
(Al/INtL)
Electric Contralled Air
(SRL)

Ironster system
Extrusion feeder
Rom teeder (trosh in $2 \mathrm{ft}^{3}$
boxes)
Use drum os bum chamber
Toper ed screw teeder
Pneumatic ironster
Rom feeder (trash in cor-
lons)

O PERATION

Inler foce wilh combustor Direct disdrarge to tray

Operat ion mode (e.g., botdh,
continuous, etc.)

Continerous

Air lock with guillotine Semicantinuous

Bum chomber is removoble Botch

from heod

Direcs disctorge into bot- Continyous

fom of fluidized bed

birect disctorge (with oir) Confinuous

below melt surfoce

Double guillotine doors

Semicontinuous 
TABLE 5-7

COMPARISON; OF CUMEUSTION TECHMOLOGIES: PHIMANEY COMBUSTION 1:99

\begin{tabular}{|c|c|c|c|c|c|c|c|}
\hline & Operotion & $\begin{array}{c}\text { Acid } \\
\text { Digestion } \\
\text { (HEDL) }\end{array}$ & $\begin{array}{c}\text { Controlled Air } \\
\text { Incinerafor } \\
\text { (LASL) }\end{array}$ & $\begin{array}{c}\text { Cyclone } \\
\text { incinerotor } \\
\text { (mourad) }\end{array}$ & $\begin{array}{l}\text { Fluidized bed } \\
\text { Incinerater } \\
\text { ('rocky Fluts) }\end{array}$ & $\begin{array}{l}\text { Molten Salt } \\
\text { Combustion } \\
\text { (Al/tNEL) }\end{array}$ & $\begin{array}{c}\text { Electri- } \\
\text { Comfrolled Air } \\
\text { (5RL) }\end{array}$ \\
\hline & $\begin{array}{l}\text { 1. General } \\
\text { deseription }\end{array}$ & $\begin{array}{l}\text { Shollow hor izontal } \\
\text { iray located within } \\
2 y_{2} \text { flt diom hor i- } \\
\text { zontal cyl. shell }\end{array}$ & $\begin{array}{l}1.8 \mathrm{~m} \text { OD } \times 1.8 \mathrm{~m} \\
\text { hor izontol cylinder }\end{array}$ & $\begin{array}{l}\text { 55. gal. drum , ith } \\
\text { seporatile heas con- } \\
\text { taining oir inlet ond } \\
\text { off-gos oultet }\end{array}$ & $\begin{array}{l}\text { Fluidized ted } \\
\text { reoctor } \\
3 \text { ff diam } \times 6 \text { f1 of } \\
316 \mathrm{ss}\end{array}$ & $\begin{array}{l}5.5 \mathrm{fl} \text { diom } \times 1211 \\
\text { high ref roctory } \\
\text { lined vessel }\end{array}$ & $\begin{array}{l}\text { Horizonte: Shamber } \\
\text { about } 6 \mathrm{ft} \text { lo: }: \text { ? }\end{array}$ \\
\hline & $\begin{array}{l}\text { 2. Combustion } \\
\text { medium }\end{array}$ & $919 \mathrm{H}_{2} \mathrm{SO}_{4}$ & Air & Air & $\begin{array}{l}\text { Granular bed of } \\
\text { Noa } \mathrm{CO}_{2} \text { fluidized } \\
\text { by uir plus } \mathrm{N}_{2}\end{array}$ & $\begin{array}{l}\text { Molten solt mixture, } \\
\mathrm{No}_{2} \mathrm{CO}_{3}, \mathrm{~K}_{2} \mathrm{CO}_{3}\end{array}$ & Air \\
\hline & $\begin{array}{l}\text { 3. Oxidizing } \\
\text { ogent }\end{array}$ & HNO 3 & $\begin{array}{l}\text { Contralled air } \\
\text { to = stotichiometric } \\
0_{2}\end{array}$ & Excess air & Stoichiometric oir & Air & $\begin{array}{l}\text { Substoichiometric } \\
\text { air }\end{array}$ \\
\hline & 4. Tempent ..te & $250^{\circ} \mathrm{C}$ & $750-870^{\circ} \mathrm{C}$ & $1100-1300^{\circ} \mathrm{C}$ & $525-575^{\circ} \mathrm{C}$ & $800-850^{\circ} \mathrm{C}$ & $850-900^{\circ} \mathrm{C}$ \\
\hline & $\begin{array}{l}\text { 5. Materials of } \\
\text { construction }\end{array}$ & Glass-lined steel & $\begin{array}{l}\text { Corbon stee1 lined } \\
\text { with most ic, re- } \\
\text { froctory molerials }\end{array}$ & $\begin{array}{l}\text { Stainless steel or } \\
\text { cot bon-steel dr uns }\end{array}$ & $\begin{array}{l}31 e^{\prime} 304 \text { stainless } \\
\text { sleel }\end{array}$ & $\begin{array}{l}\text { Sieel lined with } \\
\text { lused cost alumiin } \\
\text { bricks }\end{array}$ & $\begin{array}{l}\text { Brick and coslable } \\
\text { refroctory }\end{array}$ \\
\hline & 6. Capocisy (kg/hr) & 8 & 45 & 25 & $\mathbf{8 2}$ & 45 & 5 \\
\hline 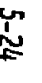 & $\begin{array}{l}\text { T. Exiernal } \\
\text { supply }\end{array}$ & $\begin{array}{l}\text { Recirculated liquid } \\
\text { from secundary } \\
\text { combustor }\end{array}$ & $\begin{array}{l}\text { Gos or ail bumer } \\
\text { on demand }\end{array}$ & $\begin{array}{l}\text { None required alter } \\
\text { inilial ignition }\end{array}$ & $\begin{array}{l}\text { Electrically heoied } \\
\text { air for stortup only }\end{array}$ & $\begin{array}{l}\text { Propone for storsup } \\
\text { only (coke used to } \\
\text { heot when idle }\end{array}$ & Electric \\
\hline & $\begin{array}{l}\text { B. Comitustion } \\
\text { controt }\end{array}$ & $\begin{array}{l}\text { Feed role, } \mathrm{HNO}_{3} \\
\text { rate }\end{array}$ & $\begin{array}{l}\text { Steam injection } \\
\text { leed rale, air rate }\end{array}$ & None & Feed rate, oir rote & Feed rate & Feed rate, oir rote \\
\hline
\end{tabular}

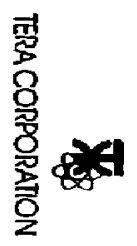


TABLE S-B

CUMPARISON UF COMBUSTIUN TECH NULUKIES: SECUNDAHY COMBUSTOR ${ }^{149}$

\begin{tabular}{|c|c|c|c|c|c|c|c|}
\hline & Operation & $\begin{array}{c}\text { Acid } \\
\text { Digestion } \\
\text { (ItEDDL) }\end{array}$ & $\begin{array}{c}\text { Comiralled Air } \\
\text { Incinerolor } \\
\text { (LASL) }\end{array}$ & $\begin{array}{c}\text { Cyclome } \\
\text { tncinerator } \\
\text { (Mound) }\end{array}$ & $\begin{array}{l}\text { Fluidized Hed } \\
\text { Incinerator } \\
\text { (Hocky Flats) }\end{array}$ & $\begin{array}{l}\text { Malten Salt } \\
\text { Combustion } \\
\text { (Al/LNEL) }\end{array}$ & $\begin{array}{l}\text { Electeic } \\
\text { Controlled Air } \\
\text { (SKL) }\end{array}$ \\
\hline I. & $\begin{array}{l}\text { General } \\
\text { deseription }\end{array}$ & $\begin{array}{l}\text { Corbon residue com- } \\
\text { bust jon completed in } \\
\text { verilcal } 2 \%-f t \text { diom } \\
\text { onwular vessel }\end{array}$ & $\begin{array}{l}1.6 \mathrm{~m} \text { OD } \times 1.8 \mathrm{~m} \\
\text { hor izontal cylinder }\end{array}$ & $\begin{array}{l}\text { Nome } \\
\text { required }\end{array}$ & $\begin{array}{l}\text { Fluidized bes of } \\
\text { chromium oxidef } \\
\text { alumina colalyst }\end{array}$ & $\begin{array}{l}\text { thone } \\
\text { required }\end{array}$ & $\begin{array}{l}\text { U-shoped path of } \\
\text { refroctory bricks }\end{array}$ \\
\hline 2. & $\begin{array}{l}\text { Combust ion } \\
\text { medium }\end{array}$ & $93 \% \mathrm{H}_{2} \mathrm{SU}_{4}$ & Air & N/A & Fluidized catalyst bed & N/A & Air \\
\hline 3. & Oxidizing ogen1 & $\mathrm{NNO}_{3}$ & Excess air & $N / A$ & Excess air & N/A & Exces air \\
\hline 4. & Temperature & $250^{\circ} \mathrm{C}$ & $950-1200^{\circ} \mathrm{C}$ & $N / A$ & $525-625^{\circ} \sim$ & N/A & $900-1000^{\circ} \mathrm{C}$ \\
\hline 5. & $\begin{array}{l}\text { molerials of } \\
\text { construction }\end{array}$ & Glass-lined steel & $\begin{array}{l}\text { Some as primiory } \\
\text { chamber }\end{array}$ & $N / A$ & $\begin{array}{l}\text { Some os primory } \\
\text { chamber }\end{array}$ & N/A & $\begin{array}{l}\text { Brick and castable } \\
\text { refroctory }\end{array}$ \\
\hline 6. & $\begin{array}{l}\text { External } \\
\text { theat supply }\end{array}$ & Electric fumoce & $\begin{array}{l}\text { Gos or oil bumer on } \\
\text { demond }\end{array}$ & N/A & None required & N/A & $\begin{array}{l}\text { Silicon corbide electric } \\
\text { hed? ing elements }\end{array}$ \\
\hline
\end{tabular}

岕

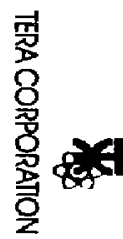

N/A - Nol Opplicable. 
rAtile: 5-9

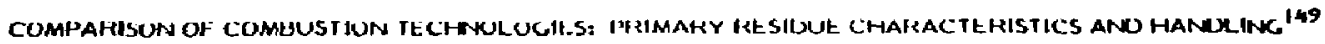

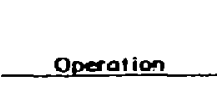

1. Kemoval method

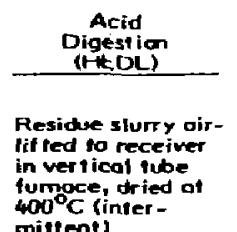

$4000^{\circ} \mathrm{C}$ (initer -

2. Residue charoc ter ist ics
a. Form

b. Bulk density g/cc

\section{Approximate} residue compo-
sifion wit $\% *$

\section{Frioble coke of dry sult ate and}

$0.5-0.85$

40\% mineral ash $60 \%$ sulfate
Confrolled Air

$$
\begin{aligned}
& \text { Incinarator } \\
& \text { (LASL) }
\end{aligned}
$$

Batch vacuum remowal

rstem

em lcallith

nat ic tronesport system

is being developed?

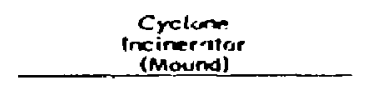

Dry Iroction (75\%): Vocuur pneumotec tronster system

at end of bum

Wei fraction (2S:): Discherryed as met hilter cake to

\begin{tabular}{|c|c|}
\hline $\begin{array}{l}\text { Fluidized Bed! } \\
\text { Imcineritor } \\
\text { (Rocky r:ols) }\end{array}$ & $\begin{array}{l}\text { Molfen Solf } \\
\text { Combustion } \\
\text { (Al//NLLL) }\end{array}$ \\
\hline
\end{tabular}

Grovity dischorge (contimuus)

Molien solif/osh sherry drained periodically to cast ing moig

Electric

Entrolled Air

\section{Eatch gravity} dischorge

1) - ines

1.).56

A4to mineral ash 1.5' corbon
$\sim 16$ scrute solts
F ine gronulor mixfure of sol:

0.97

$0.1-1.0 \%$ corbon
$>99 \%$ mi reral ash
12\% mineral ash

$15 \% \mathrm{No}_{2} \mathrm{CO}$

$18 \% \mathrm{NkO}_{2} \mathrm{SO}_{4}$

$54 \mathrm{C}$
Massive solt coke

2.2

25\% mineral ast 5 wit $\% \mathrm{C}$ $60 \% \mathrm{Ha}_{2} \mathrm{CO}_{3} \quad 954$ minerat on

Dry oshes

0.5

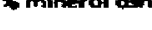

When oxidizing woste containing $\sim 15$ wi b $\mathrm{Cl}, 2$ w/ 85 , and 6 wi 9 inineral ash, bulk density $=120 \mathrm{~kg} / \mathrm{m}^{3}$. 
1 AlJLE. $5-10$

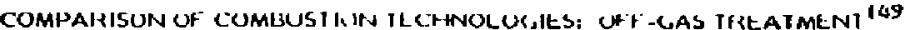

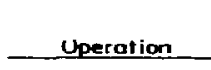

l. Ceneral description

\section{Apprax, comp. of treated of ! To (mel Hipa filtra- tion)}

尛

3. OIf-gos volume," mper kg woste
a. Leoving fino
$\sim 7$
TOMEPA
$-13$
filter

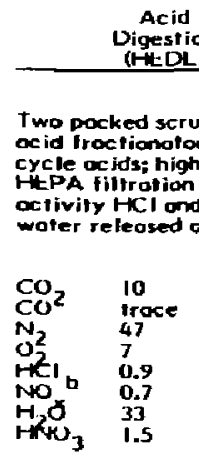

Acid
EDtion

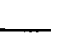

Incilverdfor
(LASL)

Gue- : h column Genivi scrubber screiser, HotA filtration.

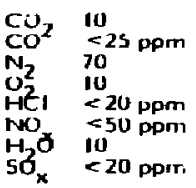

$\begin{array}{ll}\mathrm{CO}_{2} & 9 \\ \mathrm{~N}_{2} & 66 \\ \mathrm{O}_{2} & 14 \\ \mathrm{H}_{2} & 1.26 \times 10^{-3} \\ \mathrm{NO}^{2} & (1-60) \times 10^{-3} \\ \mathrm{H}_{2} \mathrm{O} & 11 \\ \mathrm{SO}_{2} & \mathrm{NO}\end{array}$

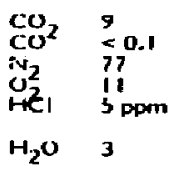

Cyclone Incinerator

Utuench spray lonk to cool and scrubber HepA filtration. beds; sintered Pilters;
tibiers.

luidized Sed (rocinerator

\begin{tabular}{|c|c|}
\hline \multicolumn{2}{|c|}{$\begin{array}{l}\text { Molten bolt } \\
\text { Combustion } \\
\text { (Al/IVEL) }\end{array}$} \\
\hline $\begin{array}{l}\text { Bogh } \\
\text { filier } \\
\text { filter }\end{array}$ & $\begin{array}{l}\text { use. pre- } \\
\text { and HEPA }\end{array}$ \\
\hline $\begin{array}{l}\mathrm{CO}_{2} \\
\mathrm{CO}^{2} \\
\mathrm{~N}_{2} \\
\mathrm{O}_{2}^{2} \\
\mathrm{NO}_{1} \\
\mathrm{NO}_{2} \\
\mathrm{SO}_{2}\end{array}$ & $\begin{array}{l}10 \\
<0.1 \\
74 \\
13 \\
<5 \mathrm{ppm} \\
30-300 \mathrm{ppm} \\
3 \\
\leq 2 \mathrm{ppm}\end{array}$ \\
\hline
\end{tabular}
\begin{tabular}{c}
$\begin{array}{c}\text { Eieciric } \\
\text { Conirodled Air } \\
\text { (SHL) }\end{array}$ \\
\hline
\end{tabular}

Pocked quench sproy, colvm and IEPA ilitrotion.

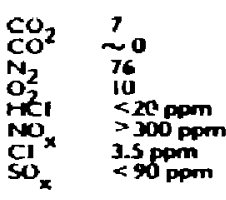

11.33
(20 nominal) $\quad 15-20$

$14-35$

$16-22$

(2) nominal)
16.5

16.5

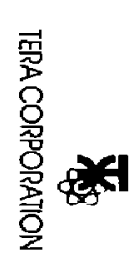

Gest estimates, not necessorily on o common busis.

b $|\cdot|_{x}=$ nitrogen ox ides. 
1 ABLE S-11

COMPARISON OF COMUUSTIUN TECHNOLOGIES: SECUNUAKY WASTES FROM OFF-GAS TREATMENT IL9

\begin{tabular}{|c|c|c|c|c|c|c|c|}
\hline & Operotion. & $\begin{array}{c}\text { Acid } \\
\text { Digestion } \\
(1+t D L)\end{array}$ & $\begin{array}{c}\text { Contralled Air } \\
\text { Incinerotor } \\
\text { (LASL) }\end{array}$ & $\begin{array}{l}\text { Crelone } \\
\text { Incimetala.r } \\
\text { (Mrouted) }\end{array}$ & $\begin{array}{l}\text { F luidired Bed } \\
\text { Inciterolor } \\
\text { (Hocky Flats) }\end{array}$ & $\begin{array}{l}\text { Molien Sall } \\
\text { Combustion } \\
\text { (Al/RVEL) }\end{array}$ & $\begin{array}{c}\text { Electric } \\
\text { Controlled Air } \\
\text { (SHL) }\end{array}$ \\
\hline i. & $\begin{array}{l}\text { wgt moste valurne } \\
\mathbf{m}_{/ \mathrm{kg} \text { waste os }} \\
\text { generated }\end{array}$ & N/A & 0.0048 & 0.0015 & None & N/A & 0.00131 \\
\hline 2. & $\begin{array}{l}\text { Approx. conp. wel } \\
\text { wailes, wits as } \\
\text { genteroled }\end{array}$ & & 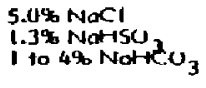 & 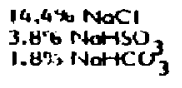 & N/A & N/A & $\begin{array}{l}7.24 \mathrm{NaCl} \\
2.34 \mathrm{Nat}_{-15 \mathrm{O}} \\
8.2 \% \mathrm{~N}+\mathrm{N}-\mathrm{U}_{3}\end{array}$ \\
\hline 3. & Treatment melthod & & $\mathrm{Fe}(\mathrm{OH})_{3} \mathrm{PPt}$ & FE $(\mathrm{OH}-)_{3} \mathrm{PPt}$ & & & Exoporation \\
\hline 4. & Final waste form & & Wet sludgeb & Wet sludge & & & Dried solp \\
\hline
\end{tabular}

When process waste contoins -15 wt $90 \mathrm{Cl}, 2$ w1 45 , and 6 wt 96 mineral ash.

b the resulting solid residue may be $c 10 \mathrm{nCi} / \mathrm{g}$ THU cond con be disposed of in conventional burial siles.
} 
Processing equipment used in rodiooctive service fails or becomes obsolete during the operoting life of the nuclear facility and becomes a woste requiring disposal. Discarded equipment normally is flushed ond decontaminated prior 10 its removal from service. Combustible components are removed wherever it is practical to do so and processed os described previously.

The reprocessing plont provides the largest and most radiaactive pieces of discarded equipment. Typical large items from reprocessing plonts consist of dissolvers. columns and concentrators which might be up to three meters in diameter and 10 meters in height. Such items can be disassembled ut predetermined points to permit removol from their operating positions. Further disassembly may be required for removal from the facility. As an alternative to removal. discarder equipment moy be stored temporarily in unused cells or in specially designed starage areas on-site for decay of short-lived radioactivity. Discorded equipment is frequently radiouctive enough to require shielding equivalent to one or more meters of concrete.

Discarded equipment of a MOX fuel fabrication plant includes such lorge items as gloveboxes as well as the smaller equipment used in gloveboxes. Elaborate containment systems are required to prevent any possible release of plutonium and transuranics to the envirans during decontamination and size reduction operations.

As shown in Figure 5-2, treatment cptions for noncombustible wostes include size reduction, compaction, melting-costing, dissolution and decontamination.

\subsubsection{DECONTAMINATION}

The decontamination of rodioactive equipment is commonly practiced by nuclear facilities prior to maintenance or storage to reduce the radiation levels and thus minimize personnel exposure during subsequent operations. The extent of decontamination which is sought has been held to reducing the radiotion to levels 
which focilitate hondling of equipment as a waste. More extensive decontaminotion can be ochieved but each decontomination operation generates additional volumes of woste which must be balanced with the net ochievable reduction in contamination levels.

A wide variety of deconfaminating agents and procedures ore ovoilable and the chosen method depends on the nature of the wostes, compotibility with handling systerns at the facility, etc. Typical decontamination solutions include alkaline permanganate, mineral acids, detergents, organic acids and cheloting compounds. Also, the use of high pressure steam has been effective os a decontumination procedure. Electro-decontamination is currently under development and is used at present to clean tools, small components, etc. SRP is planning a major electro-decontomination facility for the TRU Woste Facility. ${ }^{47}$ Technology exists to perform almost any desired degree of surfoce deconfamination.

\subsubsection{MECHANICAL DI5ASSEMBLY}

Mechanical disassembly of discarded equipment becomes necessary if it is too large to transport directly to disposal. The dismontling serves both to reduce the volume and 10 simplify handling. Disassembly may also be desirable as a prefreatment for melting, packaging, etc. Technologies for mechanical disassembly operations emplay various types of fixed apparatus (e.g., shearing machine, guillotine) and commonly used tools such as saws, shears, impact tools and culting torches. Typicolly, the operotions tend to be time consuming and require excessive amounts of lobor and can result in substantial radiological exposure to personnel.

\subsubsection{MELTOOWN AND CASTING}

Meltdown and casting of discarded equipment, ofter any required decontamination and/or mechanical disassembly operations are treatment options under development. The resulting ingot represents the minimum volume for the waste and pravides a means of fixing the radionuclide contamination.

The rodionuclides contaminating the metol equipment ore generally on the surfoce. Melting the metal incorporates most of the radionuclides into the metal mairix where they ore immobilized. Some radionuclides such os plutonium will 
be preferentiolly included in the slog covering the melt. This presents possibilities for concentrating such rodionuclides. The slog from meltdown represents o secondary waste for treatment.

Technole for metal scrap melfdown and the production of ingats is well ke.eloped in non-mucleor industries; however, the behavior of radionuclides in such processes is not fully understood. Areas under development of present include: definition of radionuclides thut will vaporize of the molten metal temperatures; distribution of radionuclides in the final ingot and slag; and development of adequate auxiliary systems (e.g.s off-gas treatment). Furnoce concepts being considered are: vacuum furnace, induction heating, autogenous melting (e.g., thermite heat source), electric orc, plasma arc and electroslog methods. Currently two melting processes, inductaslog melting and graphite crucible meltina are being investigated for densification of spent fuel bundle residues. $^{81}$

\subsection{TECHNOLOGIESFOR TREATMENT OF WET WASTES}

Wet wawes consist mainly of aqueous solutions and slurries, evoporator concen:rates, spent demir,aralizer resins, filters and filter sludges, and orgonic oils and solvents. Tregtment options for rndiooctive liquids and other wet wastes are shown in Figure 5-3.

Evaporotive processes ore generally used on aqueous wastes with high total solids content. Wastes with Jow total solids are generally treoted by nonevaporative processes to remove contaminants from liquids in order to recycle or discharge the liquid as an effluent. Organic wastes are sent to a combustion process similar to iscinerators previously described. The treutments for aqueous sols tions and slurries with high total solids contents (both dissolved and undissolved) are shown in Figure 5-3. Evaporators, drying and colcination are used os the principal treatment methods.

At reprocessing focilities, the high total solids streams with intermediate levels of radiooctivity are colled intermediate level liquid wastes (ILLW). Typical sources of ILLW at a fuel reprocessing plant include scrubber solutions from process vessel off-gas treatment systems, ion exchanger regeneronts from spent 


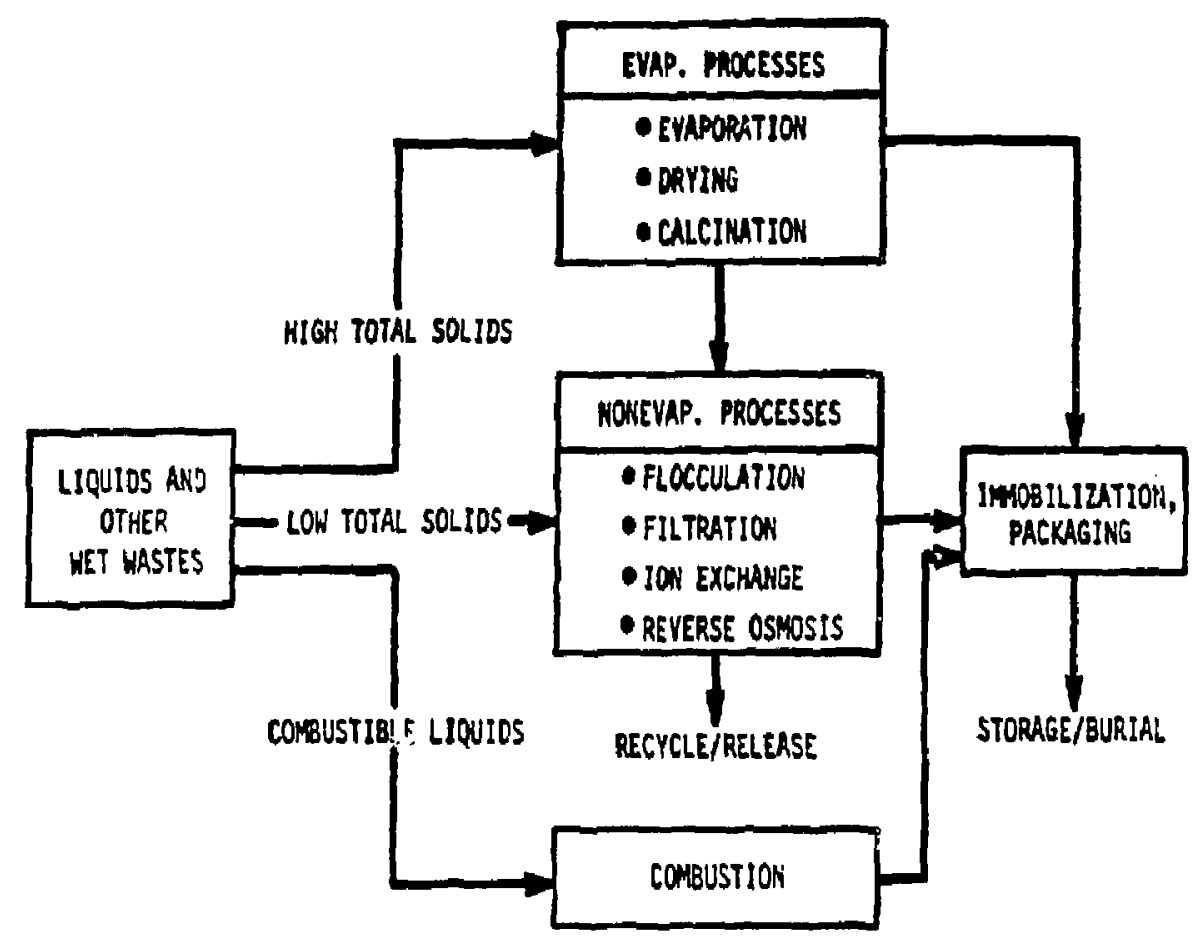

FIGURE 5-3

OPTIONS FOR RADIOACTIVE LIQUIDS AND OTHER WET WASTE TREATMENT 
fuel and/or solidified high-level woste storage bosin cleanup systems cask and plant decontamination solutions, waste solutions from solvent washing systems. and miscelloneous waste solutions from maintenance and laboratory operations. Similarly, aqueous wastes with high solids content orise from ion exchange regeneration. decontamination aperations, floor and equipment drainage systerns.

Typical organic liquid wastes from fuel cyele operations consist of process solvents (tr ibutyl phosphate diluted with $\mathrm{c}$ refined hydrocorbon diluent) labora. tory solvents. cleaning solvents and lubricants of various kinds. Waste orgonic liquids can be burned by spraying into specially adapted oil burners or conventional incinerators used for combustible wostes. The special nature of spent solvents containing radioactivity and phosphorus pose demanding requirements for off-gas treatment. Although the technology is generally available for incineration of solvents. it has mit been fully reduced to operating practice. Alternatively, evoporation of small volumes of volatile organic liquids is also a viable decontamination option.

Organic ion exchonge resins, while o combust ible yasie. ore difficult to process by conventional incineration and will require processes such os ocid digestion. fluid bed incineration and molten solt combustion. Cumbust ible filters and filter ends can be processed by conventional incinerotion techniques.

Examples of technology in use or under development for treating wet wostes are discussed below. Further discussion is found in Appendix K.

\subsection{EVAPORATION}

Evaporation is a process whereby a solution or slurry is concentroted hy vaporizing or boiling away the sulvent, normally water or mineral ocid. Evaporators; coupled with efficient deentrairment devices, provide capability for a high degree of separation for most radioactive materials. However, the inherently high operating cost of evaporation limits the applieations to those liquids which have a high concentration of dissolved solids and require high decontamination foctors. 
An evaparator consists basically of a device to transfer heat to the snlution and a device to separate the vapor and liquid phases. The principal elements involved in evaporator design are heat transfer, vopor-liquid separation, and energy utilization. Careful design of equipment is mandatory for the evaporation of waste liquids with potential for foaming, corrosion, or severe scaling. To resist corrosion and attach from acids, evoporators are usually constructed of stainless steel, inconel or other similar material and are operated at os low a temperature as is proctical. Several variations in evoporotion equipment design are available and have been used for many years in nuclear and non-nuclear industry. A more extensive discussion is provided in Appendix K.

\subsubsection{COLL OR POT TYPE EVAPORATOR}

This type of evaporator is used primarily for batchwise operation. The equipment is simply a vessel in which the liquid to be evaporated is contained and heated, normolly by steam flowing through a coil. Vapors leaving the vessel poss through an external vapor-liquid deentrainnent device and a water-cooled condenser. This evaporator has had substantial problems in the past and is typically not used in the nuclear industry.

\subsubsection{FORCED CIRCULATIONEVAPORATOR}

In a forced circulation evaporator, liquid is recirculated by a pump through the heat exchonger's tubes. Circulation rates are high. The heot exchanger is normally a separate unit to facilitate maintenance and replacement. Forced circulation evaporators are increasingly favored in nuclear applicotion because of improved performance and maintainability.

\subsubsection{MULTIPLE EFFECT EVAPORATOR}

These evaporators utilize the vapor from one effect as the heoting medium for another sffect in which boiling takes place of a lower temperature and pressure. Normally, this type is anly used for large-scale application and is not appropriate for nuclear application. 


\subsubsection{NATURAL CIRCULATION EVAPORATOR}

These are generally heated by condensing steam in shell-and-tube heat exchangers. Both vertical and horizontal fube designs are used, although the vertical design is more common. In the latter, the steam is condensed in the shell side of the exchanger and liquid circulation is induced in the vertical tubes by vopor formation. Becouse of extensive performance and maintenance problems, this evaporator is not utilized in new applications in the nuclear industry.

\subsubsection{VAPOR COMPRESSIONEVAPORATOR}

In this type of evaporator, the vopors are compressed and combined with fresh steam input, thereby making the latent heat of condensation guailable at a higher temperature and utilizing energy potential of the vapors which is otherwise discarded. This evaporator design, while oftroctive, has not yet been used in nuclear applicotion.

\subsubsection{WIPED-FILM EVAPORATOR}

This design permits evaporation of liquids to a much higher concentrotion of solids than other evaporators. Mechanical energy is used to improve heat transfer efficiency. Liquid waste is fed into o heated cylinder which contains rotating biodes or wipers. These reduce the liquid to a film by centrifugol force. The blades also serve to break up form. Wiped-film evaporators can also be operofed as dryers for waste compositions which are compatible with this mode of operation. Both vertical and horizontal wiped-film evaporators have been used for reducing Savannah River Plant wastes to salt cake products.

\section{4 .2 DRYING}

Drying involves removal of liquid through application of heat to leave o dry solid. Drying has had litfle application thus far in the disposal of liquid wastes, but increased disposal costs are expected to favor increased use of this technology in nucleor facilities. Vorious types of dryers have been used or tested to convert radiooctive liquid wastes to dry solid residues. The in-drum ar in-tank drier 
consists of a heating element immersed in the liquid to promote evaporation. This method has been used at Hanford in the in-tank solidification process for stored high-salt liquid wastes. In the spray dryer design, the solution is sprayed into o drying chamber and energy for voporization is supplied by radiant heating or by heated air. This technology has been under development at Rocky Flats for disposal of waste salt solutions. Another alternative is the fluidized bed drier, under development for LWR radioactive wastes. Modifications of all of these units are or could be made ovailable for TRU liquid waste applications.

The dried product from treatment of aquecus solutions/slurries with high solids content is generally a dry or nearly dry salt coke or powder. In many situations this material is considered suitable for storage but not disposal. The material would be inmobilized further by one of the techniques for cement, bitumen, glass, etc.

\subsubsection{CALCINATION}

Colcination, in controst to drying, is a high temperature process in which liquid wostes are dried and thermally decomposed to form stable, nonfused compounds such as oxides. Most of the calcination process development work with radioactive wastes has been directed toward treatment of high-level wastes, but the technology is also applicable to low- and intermediate-level wastes. In reprocessing focilities, some $I L L W$ streams might be combined with high-level liquid wostes as feed to a calcination process. Options include spray, fluidized bed, pot and rotary kiln calcination. The product form can range from powdery dusts to free-flowing granular material to a porous friable cake.

\subsubsection{REVERSE OSMOSIS}

Reverse osmosis is o method of purifying waste streams bosed on the phenomenon known as asmotic pressure. The process involves the seporation of solutions of different solute concentrations by a semipermeable membrane. When pressure is applied to more concentrated solution in excess of its osmotic pressure, solvent will flow across the membrane to the less concentrated side. Reverse osmosis and the related membrane technology - ultrafiltrotion - have potential rules for processing TRU contaminated liquid waste. 


\subsubsection{FLOCCULATION}

Flocculation and corrier precipitation processes have been used extensively for cleanup of non-high-level liquid wasies commonly os pretreatment to filtrotion and ion exchange palishing. Chemicals are odded to the liquids to produce flocculant precipitates. The radioactivity may be rem aved by direct precipitation, by absorption on the resultant flocs, or by entroinment in the settling precipitates. The effect is to concentrate the radioactivity into a small volume of insoluble sludge which can be separated by settling or filtering. The solution can be further treoted, if needed, by ion exchange. Flocculation and precipitation methods have been used for treatment of low-level liquid wastes at ERDA facilities and Nuclear Fuel Services (NFS). Use of this technology for LLLW at reprocessing plants is exemplified by the treatment system in place at NFS which is used to treat evaporator and acid fractionator condensates, cooling water, building drains, laundry wastes, and similar LLLW.

\subsubsection{FILTRATION}

Filtration is the most commonly used method for the removol of precipitates and particulate matter from liquid waste streams. Other methods used to separate solids fron liquids include liquid cyclones (hydroclones), and centrifugation, settling and decantation. Centrifuges are mechonically driven devices of variable design; solids-bearing fluids are fed into a rotating section which imparts rotational motion to the suspension. Centrifuges have been used to concentrote and dewater waste slurries (including resins) at reactors. A hydroclone is a simple device in which fluid pressure energy is used to create rotational fluid motion in a cyclone thus separating solids from liquids.

The porous media used in filtration can be fobricated in a multitude of physicol forms. Granular media employed in deep beds for filtering aqueous wastes include sand, diatomaceous earth, anthracite and activated carbon. Combinations of the various filter medio are sometimes used. Typicol examples of filters with nongranular media include: 
- Disposable filters

- Precoat filters

- Metallic non-cleanable filters

- Metallic reclaimable filters

\subsubsection{IONEXCHANGE}

Ion exchange methods have been widely used for removing dissolved rodioactivity from LLLW. The process involves exchonge of ions between the liquid ond 0 solid metrix confoining ionizable polar groups. Both cation and anion exchange resins and zeolites ore used. When the exchongers have become fully looded they ale removed from service and treated as radiactive waste or, alternately. they may be regeneroted by strong acids and strong bases: thus yielding radionctive liquid wastes of high salt content. Development of a promising nev process for decontaminating liquids by use of inorganic ion exchange resins has been reported recently by Sondia Laboratories. Natural chromotographic seporation of simulated wastes hos been demurstrated in passing through the pocker bed af sadium "titarate" ion exchanger. Actinides show a particularly high affinity for these materials and future interest in waste partitioning could spark. on interest in the process for that purpose.

\subsection{VR TECHNOLOGY ANALYSIS}

The potentiol role of any volume reduction (VR) technology in the treatrient of low-level waste generated either of nuclear fuel cycle facilities or at various non-fuel cycle facilities will depend upon o combination of design economic, and regulotory criterio. Any technology that is seriously proposed must be copable of providing o safe, reliable, and cost-effective means of processing waste and result in a concentrated woste stream that can be readily treated with availoble technology. Whether this technology is utilized at the woste generotor's focilities is dependent upon both regulatory and economic ec nsiderations. The evoluation of a VR technology should include the factors given in Table 5-12. 
TABLE 5-12

VR EVALUATION FACTORS

Design Basis

- Application

- Process Flow Sheets

- Equipment Configuration

- Pretreatment Requirements

- Copacity

- Materials Processed

- Materials of Construction

- Operating Parameters

- VR Copobility

- Decontamination Factor

- Design Costs

- Copitol

- Installotion

- Operoting

- Secondary Woste Streams

- Auxiliaries Requirements

Porameter Descriptions

- Secondary Woste Stream

- Product Characteristic

- Operaily Snnditions

- Accidents/Upset Conditions

\section{Operating Foctors}

- Operoting History

- Performance Dato

- Limitations

- Reliability

- Availability

- Maintainability

Cost Factors

- Equipment Copitol Cost

- Installotion Cost

- Operating Cost

- Processing Cost

- Cost Effectiveness

Applicability to TRU Woste

- Wastes

- Design Factors

- Retrofit/New listallation

- Compatibility

- Operability

- Licensability 
The two major incentives for volume reduction ore economics and regulatory criteria. These two incentives include number of considerations and are closely coupled. Becouse of changing regulatory critieria, previous proctices may become economically and/ar regulatively unattroctive. In addition, with the increose in the number of nucleor plants and other radionctive waste generotors. and the increase in operoting costs associated with woste management, the operoting philosophies and proctices of waste management come under close scrutiny and a means of reduçing these costs, such os volume reduction (VR). becomes more attractive.

In evoluating the econamics of systems for rodioactive waste management, oll system activities must be identified and estimates of capital, operating and maintenonce costs made for each of them. These activities may include:

- Collection of waste

- Tiransport of the waste to the treatment center

- Nonitoring ond sorting before treatment

- Treotment

- Nonitoring of the treated waste before disposal

- Disposal of treated vioste

- Conditioning of the concentrated radioactive material before storage or disposal

- Starage or final disposal of the conditioned concentrated material

As with other chemical pracess systems. the costs of treating radwaste are made up of two companents - capital costs and operating costs. The capital costs art mode up of the items listed: Table 5-13. These include the costs of process equipment and piping. the building costs including the structure and building facilities, and the other items classically consideres in capital cosi itemization. The operoting costs include all non-capital costs; o portial list is presented in Table 5-14. 
TABLE 5-13

MAJOR DIRECT CAPITAL COSTS

- Process Equipment

- Building Costs

- $\quad$ Piping

- Instrumentation and Controls

- Electricol Service

- Spare Parts

- Contingency 
TABLE 5-14

MAJOR IN-PLANT OPERATING COSTS

- Row materials

- Utilities

- Stearn

- Electricity

- Fuel

- Cooling water

- Labor

- Supervision

- Payrall overhead

- Supplies (including spore ports)

- Laboratory

- Maintenonce

- Depreciation

- Insurance and property taxes

- Plant overhead 
Operating costs are subject to two classifications. One of these relotes to whether the operating expense is constont, and therefore "fixed," in a given plant when operating of different froctions of copacity. Those costs which change with the level of operation in a given plant are colled "variable" costs. In process plants, the costs of row materials and utilities tend to be variable costs while all other costs tend to be fixed costs. Operating costs con also be classified as "direct" or "indirect." A direct cost is one which can logically be assigned clearly to one particular product, and an indirect cost is one which can only be ossigned to a particular product on some orbitrary basis. In a singleproduct plant, e.j., electricity, all costs are direct costs. In today's operotions, direct waste disposal casts include:

- In-plant processing costs (includes maintenance)

- Personnel cost

- Moterial cost

- Energy cost

- Transportation

- Buriol Cost

- Handling

- Perpetual burial fees

- Surcharges

In determining the potential rcle of volume reduction in a rodwaste management systern, it is important to determine the cost/benefit ratio of volume reduction. If we assume a case where a volume reduction system is added to a nuclear plant in between the waste concentrate tanks and solidification system, and a case where no such system is used, the cost/benefit ratio is defined in terms of the increased copitol cost of such o system versus the reduced operoting costs.

In order to fully evaluote the economics of combining VR components into specific process treatment systems, consideration must be given to the ultimate disposition of concentrated radioactive woste streams. Normally, cuncentrated 
rodioactive wostes ore solidified and prepared for eventuol off-site shipment and disposal. The cost factors associated with the pockoging and disposal of solid wastes ore important. Volume reduction equipment will vory, depending upon the specific philasophy of the overoll rodwaste manogement scheme, and might include simple dewatering equipment, evaporators, film dryers, and/or more complex components such os colcination units. For example, evoporative type woste treatment systems may be well suits $d$ to the direct adaptation of a colcination unit, whereas reverse osmosis systems may require additional postprocessing equipment to increase the colcination unit inlet solids concentrations to a level suitable for efficient operations ( $\sim 10$ percent). Such faclors shauld be considered in economic analysis.

Solid waste disposol costs ore greatly affected by the regulatory requirements for packaging, transportation, and buriol. Tha selection of a typicol processing system is tied to the disposal site and must include a detailed evaluation of bath operating and capital costs and encompass the following critical items:

- Quantity, size, and type of consumable containers required

- Quantify of solidification agents, cotalysts, and additives required

- Plant labor costs for processing ond handling

- Freight charges bosed on volume rodioactivity, weight, and shielding requirements for each type of woste material

- Leasing of reusable shipping casks and containers (if casks are to be purchosed, the cost should be included as a copital cost)

- Burial fees including container surcharges for caik unlooding and radiation surchorges

- Decontamination requirements for shipping contuiners and cosks

- General shipping logistics 
- Power requirements

- Support services such as steom, control oir, flushing woter, ond cooling woter

\subsection{DOE EXPERIENCE WITH VR TECHNOLOGY}

DOE has numerous programs under development for TRU waste processing; howeves. present TRU waste reduction is limited to compaction as indicated in on onalysis of DOE's Woste Information Manogement System. 129 of the facilities providing such information it was indicated that in Fiscal Year 1978 Monsanto Research Corporation had realized o volume reduction foctor for its compactibie waste of 4 . Rockwell International a factor of 1.76 and Lowrence Livermore Laboratory by a factor of 2.5 . 


\subsection{MMOBILIZATION TECHNOLOCIES FOR TRU WASTES ${ }^{5134,31.53747682-84}$}

The term "immobilizotion." as used in this report, refers to a treatment designed to reduce the mobility by fixation of the "os generated" and/or final treated forn of the TRU wastes. This is typically accomplished by incorporating the wastes into a monolithic solid of law dispersibility.

The processes and schemes currently being developed to reduce the volume of the combust ible alpho wostes will likely generate residues from which the bulk of the plutonium con be recovered by aqueous leaching methods. However. in oll coses there will probobly still remoin vorious plutonium-contoining solid residues that do not merit further processing for plutonium recovery. These residues-powders. ashes, precipitates-will be characterized by their large surface arec and will require densification and incorporation into some immobile. nonleachable form for sufe, long-term storage. In addition to combustible waste liquid waste, especially that produced by small volume generators. may be directly fixed.

Immobilization technologies can be divided into those that are commerciolly avaiiable and in use. and those under development to provide improved produc: integrity. The najor immobilizing agents in use include urea-formoldehyoe resins, hydraulic (portland) cement and cernent plus additives. and biturnen (espholt)

Two other processes used to immobilize waste liquids involve the use of absorbents and evuporotion to a salt cake. The lotter process is not used commercially, but it is being used at Hanford to irrmobilize sodium salt solutions occumuloted during DOE's plutor.Jm-production operations. Atomics Inter nationol olso proposes to use the salt me lio of its molten-solt combustion preress to encopsulate the osh product. Other immobilization technologies under de =lopment that will be discussed include clay fixation. glass formation. and pel'atization. 


\subsection{ABSORPTION ${ }^{51,31}$}

Absorbents have been widely used in the nuclear industry to immobilize liquids (by fixation with a sorbent material) for transportation and storoge of low-level liquid wastes. The product is quite leachable and for from monolithic. Therefore this technique is now largely reserved for oils, solvents, and other organic and incrganic liquids that are difficult to immobilize by other available means. Widely used absarbents include vermiculite, diatomite, and various dehydroted clays. Toble 6-I provides fixation data on three common sorbent materials. This technique would be utilized to obsorb TRU- and fission-product contaminated aqueous and non-aqueaus liquid waste. While it is not expected that lorge volumes of TRU-contominated liquids would be absorbed, sorbents would be used, e.g., with compacted waste to absorb small quantities of liquid from spills, efc.

\subsection{SALT MATRIX ${ }^{51}$}

Hanford has been converting DOE-generated liquid wastes stored in underground tanks to massive solt cakes by the in-tank solidification process. The woste liquid, typicaily containing about IM NaOH, 2.5 M $\mathrm{NaNO}_{3}, 0.4 \mathrm{M} \mathrm{NaNO}_{2}$, $0.3 \mathrm{M} \mathrm{NaAlO}$, and $0.1 \mathrm{M} \mathrm{Na}_{2} \mathrm{CO}_{3}$, is transferred to on external evcporator for water removal. The concentrated slurry is tronsferred to the final storage tonk for cooling and crystollization. Liquid remaining after crystallizotion is returned to the evaporator, along with fresh feed, until the desired fill of the final storage tank is obtcined. The resulting salt cake is damp and contains about 20 to 30 vol\% concentrated liquor.

Recent work at both Hanford and the Savannah River Loborotory has shown that wiped-film evaporators can reduce the water content of stored salt wastes sufficiently for the product to solidify on cooling. Application of this fechnology would eliminate the recycle of mother liquor from the crystallizer-storage tank back to the evaporator and result in a one-step evoporation process. Wiped-film evaporotion technology was briefly discussed in Section 5 . 
TABLE 6-1

FIXATION OF LIQUID WASTES USING SORBENTS ${ }^{31}$

\begin{tabular}{|c|c|c|c|c|c|c|c|c|c|c|c|}
\hline \multirow[b]{2}{*}{$\begin{array}{r}\text { Sorbent } \\
\text { Material }\end{array}$} & \multirow[b]{2}{*}{$\begin{array}{l}\text { Liquid } \\
\text { Tested }\end{array}$} & \multirow{2}{*}{$\begin{array}{l}\text { Volume } \\
\text { Ratio. } \\
\text { Sorbent } \\
\text { Liquid }\end{array}$} & \multirow{2}{*}{$\begin{array}{l}\text { Liquid } \\
\text { Volume, } \\
\text { me }\end{array}$} & \multirow{2}{*}{$\begin{array}{c}\text { Sorbent } \\
\text { Vol ume, } \\
\text { mp }\end{array}$} & \multirow{2}{*}{$\begin{array}{c}\text { Sorbent } \\
\text { Weight } \\
g\end{array}$} & \multirow{2}{*}{$\begin{array}{l}\text { Liquid } \\
\text { We ight, } \\
9\end{array}$} & \multirow{2}{*}{$\begin{array}{c}\text { Test } \\
\text { Period, } \\
\text { hr }\end{array}$} & \multicolumn{2}{|c|}{ Free Liquid } & \multicolumn{2}{|c|}{$\begin{array}{l}\text { Net Sorbent } \\
\text { Sorbed Liquid }\end{array}$} \\
\hline & & & & & & & & $\begin{array}{c}\text { Votume. } \\
\text { me }\end{array}$ & 7 & $\begin{array}{l}\text { Vot } \\
\text { Ratio }\end{array}$ & $w t$ \\
\hline Vermiculite ${ }^{(a)}$ & wa ter & 2.06 & 1000 & 2062 & 167 & 1000 & 24 & 260 & 26 & 2.79 & D. 23 \\
\hline Vermiculite & water & 2.06 & 1000 & 2062 & 167 & 1000 & 72 & 250 & 25 & 2.75 & 0.22 \\
\hline Vermiculite & water & 2.0 & 1000 & 2000 & 162 & 1000 & 0.5 & 400 & 40 & 3.33 & 0.27 \\
\hline Vermiculite & $\mathrm{N \Gamma H}$ (b) & 3.0 & 1000 & 2000 & 162 & 762 & 0.5 & 360 & 36 & 3.13 & 0.33 \\
\hline Vermiculite & NPH & 2.0 & 500 & 1000 & 80 & 382 & 24 & 140 & 28 & 2.78 & 0.29 \\
\hline Vermicul ite & $\mathrm{NPH}$ & 3.0 & 500 & 1500 & 123 & 382 & 24 & 0 & $\mathbf{0}$ & $<3.00$ & $<0.32$ \\
\hline Vermiculite & water & 2.0 & 500 & 1000 & 82 & 485 & 72 & 70 & 14 & 2.33 & 0.20 \\
\hline Vermiculite & water & 3.0 & 500 & 1500 & 120 & 485 & 72 & $\mathbf{0}$ & 0 & $<3.00$ & 0.25 \\
\hline Zorb-A1) & water & 2.0 & 500 & 1000 & 611 & 485 & 72 & 109 & 22 & 2.56 & 1.63 \\
\hline Zorb-AII & water & 3.0 & 500 & 1500 & 953 & 485 & 72 & $\mathbf{0}$ & $\mathbf{0}$ & $<3.00$ & $<1.96$ \\
\hline $\operatorname{San}-i-\operatorname{cel}^{(0)}$ & water & 2.0 & 500 & 1000 & 363 & 485 & 72 & 23 & 5 & 2.10 & 0.79 \\
\hline Sars-i-cel & water & 3.0 & 500 & 1500 & 541 & 485 & 72 & 0 & D & $<3.00$ & $<1.15$ \\
\hline
\end{tabular}
(b) NPH - normal paraffin hydrocarbon
(c) Dried clay granules - Wyandotte corp.
(d) Processed corn cobs - Paxco, Inc. 


\section{UREA-FORMALDEHYDE RESINS 51537076}

The urec-formoldehyde (UF) used in radwoste applications is o viscous. watersoluble liquid containing partially polymer ized monomethylol urea and dimethylol urea. It is mixed with neutral waste solutions in the proportion of $1: 3$ volumes of woste liquid per volume of UF. Polymerizotion is initiated by the addition of on acid cotalyst to lower the $\mathrm{pH}$ to abcut 2 . A concentrated solution of a weok acid such os sodium bisulfate is normaliy used.

The waste liquid or slurry is mixed with the desired amount of the resin by pumping the two streans through cti in-line stotic mixer. The cotolyst is blended separctely os the waste mixture enters the storage drum. The preferred formulations begin to gel within one or two minutes, and the woste is generally well solidified within half an hour. Curing to a reasonably hard. free-stonding solid continues over a period of severd hours. during which time a small omount of free, slightly acidic water is often releosed. Absorbents; cement, or more urea-formaldehyde liquid have been added atter gelling to obsorb this residual water.

Water is physically entrapped in products prepared from oqueous salutions. In an open system: the block can dry out and become friable. The tendency to dry out is much less severe with solidified ion-exchange resins. While this agent is used in the commercial reactor industry. its problems with free-stonding woter ma; make it unattractive for new applicotions such as for TRU waste. Appendix $D$ provides a more complete description of UF.

\subsection{CEMENT}

Immobilization of rodioactive wastes by incorporotion into hydroulic cements. os typified by portland cement, has been practiced for many years. The optimum proportions of cement and waste vory with the type of waste to be immobilized. For solid waste materials, such os oshes or colcines. the solidified cement products can contain up to about 75 wt $\%$ waste. Solidified products made with aqueous waste solutions and slurries are limited to about $33 w+\%$ waste, including 
the water fraction of the waste. A certain minimum proportion of water is required to obtain a workable mix. Minimum water/cement weight ratios for typical cements are about 0.22 to 0.25 . Some waste solids, such as ferric hydroxide sludges and ion-exchange resins, will absorb large amounts of water. This excess water must be supplied with the solid to prevent the latter from sequestering the required water from the cement and producing a dry unworkable mix. Too much water. however will reduce the strength and may result in a layer of free water on the surface of the solidified product.

Several additives have been used to improve the setting properties, leachability. or the volumetric efficiency of cement. These include absorbents ond ionexchange materials such as vermiculite cloys. plaster of paris, and socilum silicate.

Despite the years of experience. solidification with cement is still an ort. Eoch new waste application must be considered individuolly becouse of possible interactions between the woste constituents. Appendix $E$ provides a more complete discussion of cement.

\subsection{EITUMEN 51.74 .83 .84}

Bituminization systerns for immobilizing both liquid and solid radwostes are used in several foreign countries. but experience with bitumen in the United States hos been limited to developmental siudies. primarily of ORML. Bitumen, or asphalt. has certain properties that are odvantageous for immobilizing low-and intermediote-level wastes: it is chemicolly inert; it has good cooting properties: and it possesses a certain degree of plasticity.

Perhops the greatest advantoge of bituminization is thot of the operating temperature of 150 to $250^{\circ} \mathrm{C}$ over 99 percent of the woter evoporotes, resulting in a volume reduction of up to fivefold compared with conventional cementing techniques for products made with evaporator concentrates. Typical bitumen 
products contoin 40 to $60 \mathrm{wt} \%$ waste solids. Bitumen is also on effective seolant for other waste forms, such as concrete, as well as for sealing wasie containers internally to minimize contact with the waste form.

Several techniques have been developed and used for incorporoting waste into bitumen. These include a stirred-evaporator batch process, a turbulent-film evaporator continuous process, and o screw-extruder continuous process.

The extruder consists of two or four screws operating in a steel barrel that is divided into several stages heated seporately with steam. Preheated bitumen and waste are continuously pumped into the first (cooled) stage, where the rorating, self-cleaning screws mix and knead the waste with bitumen and transport the mixture forward through the heoted stoges to the dischorge end. Water is continually evoporated and leaves as steam through large steam domes. The steam, which contains a small amount of entrained radiooctivity, is filtered to remove oil and tars, condensed, and returned to the low-level water treotment system.

Bitumen shrinks up to 30 percent on cooling, and a better fill can be obtained by allowing the receiver to cool ofter incrementol additions. A complete fill moy not be desiroble for the more radioactive wastes becouse of radiolytic swelling at accumulated doses of about $10^{7}$ to $10^{9}$ rads.

Une of the major drawbocks to bitumen is its potential fire hozard, particularly if used to encopsulate oxidonts such os nitrotes, nitrites, or manganese dioxide. The combustion problem is minimized by using bitumen grodes with high flash points. Improved safety con also be obtained by substituting more expensive polyethylene for bitumen.

A more thorough discussion of bitumen is provided in Appendix $C$. 
The previously described salt cake produced by Honford's in-tank solidification program is not considered the most desirable form for long-term storoge becouse of the leachability of salt. The Atlantic Richfield Honford Company has been developing hydrothermal processes that can be used to incorporate the salt into aluminosilicate (clay) minerals. In the basic process, concentrated alkaline solt solution is reacted with a powdered clay, such as koolin or bentonite, at 30 to $100^{\circ} \mathrm{C}$ to form the insoluble mineral cancrinite, which contains sodium nitrate as part of the minerol cagelike struciure. The stoichiometry of the reaction requires two moles of sodium hydroxide for each mole of concrinite formed. Water, fission products, and other minor constituents ore trapped within the mineral coges and in the channels enclaseo by the coges.

Three versions have been studied, the lean-cloy process, the rich-cloy prucess, and the clay-calcination process. In the lean-clay process, cancrinite crystals are formed by the stoichiometric addition of clay to the salt waste. The crystals are washed, mixed with a binder, and formed into massive shapes (e.g., bricks). In the rich-clay version, the waste solution is mixed with excess cloy, which serves as a binder for the concrinite crystals. In the clay-colcinotion process, the cancrinite product from either the lean-clay process or the rich-clay process is molded into bricks and fired at about $800^{\circ} \mathrm{C}$ to convert it to nepheline, onother durable oluminosilicote mineral. Clay can also be mixed with salt cake and fired oirectly to form nepheline bricks.

The rich-clay process has fewer and simpler processing steps than the other versions. The solt wostes from the in-tank solidification (both liquid and solic) are mixed with suifable clay minerals in an extruder-mixer to produce a soft, peanut butter-like product thot hardens on aging or curing to an adobelike block. The rich-clay praduct is generally softe:, more leachable, less cohesive, and hos a greater volume (by about 60 to 100 percent) than the product of the claycalcination process. 


\subsection{GLASS $50-52$}

Glass is often considered on ideal form for immobilizing radiooctive wastes because of its chemical durability and low leach rates. It also has the odvantage of high thermal conductivity, which is important for heat dissipotion and temperature control during the storoge of heat-generoting high-level wastes.

In some ways, glassmaking is simplified for non-high-level TRU wastis becouse of the much lower radioactivity and because many of the mojor nonmetallic constituents of such wastes are those used in conventionol glass formulations. Ashes and zeolites, for example, contoin alumina and silica. Sadium salts decompose on heating to provide sodium oxide, a major constituent of sodo-lime glasses. It is usually necessary to add glass-forming additives or frits to the woste moterial to reduce the melting temperature to the desired range of 1000 to $1200^{\circ} \mathrm{C}$, to ensure the formation of a homogeneous glass, and to provide a sufficiently low viscosity for the melt to flow into the waste container. Borax or commercially available glass frits can be used for this purpose. Various commercial melter designs can be used.

Only limited work has been done with TRU contaminated waste and glass. This has included the immobilization of Hanford contaminated soil (Hanford basalt) as well as osh from o pyrolysis-gasification process developed at Battelle PNWL. All of the products made with Hanford soil were dense $\left(2.4102 .6 \mathrm{~g} / \mathrm{cm}^{3}\right)$ glasses contoining small inclusions of white, crystalline quartz located in the top $1-$ to 2-cm portion.

Charges containing pyrolysis-gasification residues were prepared by mixing o pulverized ash residue with appropriate amounts of a zinc borosilicate glass frit that has been studied extensively for fixation of commercial high level waste. The frit/osh ratio was varied from 80:20 to 60:40. 
A variety of pelletizotion processes have been used in DOE and commercial fuelfabricotiun facilities to prepore pellets or compacts of uranium dioxide, plutonium dioxide, and mixed oxides for nuclear fuels and in other programs. Wore recently, several DOE loboratories have begun investigations of the adaptation of these processes to immobilization of solts, calcines, and ashes from radiooctive waste.

The two processes being studied most intensively are cold pressing and vocuum hot pressing. The major difference between the two processes is that the coldpressed pellets are sintered to insoluble products by o neat treatment after pressing, whereas the hot-pressed product is sintered during pressing. In both processes the sintering temperature is about $1000^{\circ} \mathrm{C}$. An optional surface "inertification" step can be considered in which the pellet surfoce is sealed wit. o cooting of ceramic, metal, or epoxy.

An odaptation of this technology is being proposed for low-level commercial woste processing of the resultant material from a fluidized-bed/calciner/ incinerator. This technology might be utilized for TRU Waste.

\subsection{NODIF IED VINYL ESTER RESINS ${ }^{76}$}

Several other organic polymers have been examined as medio for immobilizing low-level radionctive wastes. Among the polymerized resins, water-extensible polyester or modified vinyl ester resins have been developed. At present, only one rodwoste solidification process using polyester resin is offered commercially. This system, like those using UF resins, encapsulates the waste which is combined with the matrix moterial prior to oddition af a cotalyst solution that promotes solidification. However, in the polymerization of polyester resins, water is not produced as it is in the polymerization of UF resins. The waste solutions from the chemical cleaning of Dresden Unit I are schedulec to be solidified using polyester resins. This technology might be opplicable to ThL Woste. 


\subsection{COMPARISON OF AGENTS}

The leoch rote of immobilized woste in water is one of the most important criterio used to evaluate the potential hazards of rodioactive waste handling and storage operations. Leach rates are commonly determined by measuring the fraction of a given radioactive constituent that leaches from the solidified waste over a period of time using a specified leach test. The results are expressed as grams of waste solid dissolved per unit area per day. This term is perhaps a little misleading, since cerfain constifuents often leach ot o foster rote than the bulk waste solid. Table 6-2 presents limited data available on various immobilizotion ogents.

Immobilization of rodwastes by incorporation in cement has been procticed for several decades, but, despite these years of experience, solidification with cement is not completely understood. Becouse of the complex chemistry (interactions or lack of interactions between the waste constituents and cement), it is generally conceded that each new application must be considered and tested individually. Solidification with cement and urea-formaldehyde or polyester resins does not require the application of heat as does solidification with bitumen. Obviously, the flammability of organic solidification agents (especially at elevated temperotures) is a factor that connot be ignored when they are used. Speaking brogdly, the organics can accommodate a wide ronge of wastes and waste proportions, whereas cement solidification requires o rather rigid formulation.

Table 6-3 gives a qualitative comparison of cement, urea-formaldehyde resins, madified vinyl ester resins, and bitumen. Only a limited cioto bose is available on immobilization ogents and this points out the need for additional effort in this area. 


\section{TABLE 6-2}

WASTE FORM AND IMMOBILIZATION AGENT

LEACHRATES ${ }^{51}$

$\begin{array}{ll}\begin{array}{l}\text { Woste Product } \\ \text { Colcines }\end{array} & \begin{array}{c}\text { Leach Rates } \\ \left(\mathrm{g} / \mathrm{cm}^{2} \cdot \mathrm{d}\right)\end{array} \\ \text { Ceramics (Phosphates) } & 5 \times 10^{-5}-5 \times 10^{-2} \\ \text { Glasses } & \\ \quad \text { Borosilicote } & 7 \times 10^{-8}-5 \times 10^{-3} \\ \text { Phosphate } & 2 \times 10^{-8}-3 \times 10^{-3} \\ \text { Aluminosilicate } & 3 \times 10^{-8}-7 \times 10^{-6} \\ \text { Bitumens } & 5 \times 10^{-7}-3 \times 10^{-4} \\ \text { Cements }^{2} & 5 \times 10^{-6}-7 \times 10^{-2} \\ \text { Grouts }^{3} & 5 \times 10^{7}-8 \times 10^{-4}\end{array}$

1 For plutonium-amercium wastes the leach rate is $2 \times 10^{-8}-10^{-7} \mathrm{~g} / \mathrm{cm}^{2}-\mathrm{d}$

2 For plutonium-amercium wostes the leach rate is $2 \times 10^{-9}-10^{-7} \mathrm{~g} / \mathrm{cm}^{2}-\mathrm{d}$

${ }^{3}$ For plutonium-curium waste the leach rote is $7 \times 10^{-8}-2 \times 10^{-7} \mathrm{~g} / \mathrm{cm}^{2}-\mathrm{d}$

${ }^{4}$ For alkali and alkaline-earth elements 
TABLE $6-3$

COMPARISON OF CLMENT, UREA-FORMALDFHYDE RESIN, BITUMEN, POLYESTEH RESIN AND GLA5S WIEN USED AS SOLIDIFICAJION AGENTS ${ }^{76}$

\section{Comporison Foc10r}

Shelf life of immobilixing ogen! Mix Iluidtsy

Mixer cleanbility

Chemicol toletances

Borit ocid Solution

$\mathrm{Na}_{2} \mathrm{SO}_{4}$ Solution

Alkaline Solution

Landry det. Sol'n

Orgonte Liquids

Ion exch. resires

Sludges

g)

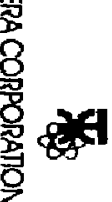

Combuntibility

Freeze/ thaw resislonce

Leoch resislonce

Without additives.
Cement'

Long

Poor

Poor

Poor

Foir

Good

Poor

Poor

Foir

Good

Low (0.5)

Monolith

1.5-2.0

Good

Seldom

Good

No

Foir to good

Moder ote 10 high
Verr pood

Good, may require
Urea formoldehyde

Short (months)

Good

Grood

Cood

Reduced Elficiency

Reduced Elliciency

Poor

Poor

Good

Moderate (0.6-1.0)

Monolith

1.0-1.3

Foir

Occosionally

Fair

Foir lloces woter and

strength in open system)

Polyester

Bifumen

Gloss$$
\text { Yestre }
$$

Poor

Low to inoderaie

Long
Good
Foir
Good
Good
Good
Foir
Foir
Good
Good
Moderate (0.6-1.0)
Mornolith
I.0-1.3
Good
Seldon
Good
Good
Yes
Untenown
High

Long

Fair

Foir

Good

Good

Coor

Foir

Fair

Foir

Good

High ( - 2)

Manolith

1.0-1.5

Waler evoporates during preporations

Never

Good

Good

Yes

Grood

Monterate to high
Long

Fair

Fotr

Good

Cood

Good

Good

Good

$\operatorname{cood}$

Good

Moderale

Monolith

I.3-1.5

Woter evoporoles

during preporation

Never

Foir

Very Cood

No

Cood

High

2 Defined as the ratio of the volume of radwaste treated to the valume of final product. 


\section{7,0 REFERENCES}

1. National Academy of Sciences, National Research Council, Commission on Natural Resources, Committee on Radioactive Waste Monagement, Ponel on Lond Burial 1976. The Shallow Land Burial of Low-Level Radioactively Contaminated 5olid Waste. Woshington, D.C.

2. Battelle Narthwest Loboratory. "Transuranium Radionuclides-A Manual of Good Proctice." BNWL-SA-3075, Jonuary 1970.

3. U.5. Environmental Protection Agency 1977. "Considerations for Environmental Protection Criterio for Radioactive Waste." December 1977.

4. Walton, R. D., et al, "Partitioning-An ERDA Overview." NR-CONF-001. Proceedings of the Nuclear Regulatory Commission Workshop on the Management. of Radionctive Waste: Waste Partitioning as an Alternative, June 8-10, 1976.

5. TERA Advanced Services Corporation. "Inventory and Sources of Transuranic Solid wastes," prepared for Lawrence Livermore Laborotory. Revision I. May 1979.

6. DOE Nianuel Chapter 0511. "Radioactive Waste Management." DOEM-05 II-01. September 19, 1973.

7. TERA Advanced Services Corporotion. "Transuranic Contaminated Waste Functional Definition and Implementation," prepored for Lowrence Livermore Lobora10ry. Fesbruary 1980.

8. Los Alamos Scientific Laboratory. "Guidelines for the Interim Storages of AECGenerated Solid Transuranic Wastes." LA-5645. June 1974.

9. U.S. Atamic Energy Commission. "Environmental Survey of the Uranium Fuel Cycle." WASH-1284. Aprii 1974.

10. U.S. Energy Research and Development Administration. "Alternatives for Mianaging Wastes from Reoctors and Post-Fission Operotion in the LWR Fuel Cycles," ERDA 76-43, Vols. 1-5. Noy 1976.

II. TERA Advanced Services Corporation. "Transuranic Contaminated Waste Container Characterization and Data Base", prepared for Lawrence Livermore Laboratory. 1980.

12. Jumps, J. J. "Current Practices for Disposal of Solid Low-Level Radionctive Waste," Radioactive Woste from the Nuclear Fuel Cycles, AlChE Symposium Series No. 154, Vol. $72,1976$.

13. U.S. Atomic Energy Commission, Division of Reactor Develrpment and Technology, "Land Burial of Solid Radionctive Wastes: Study of Commercial Operations and Facilities." WASH II43. 1968. 
14. Godbee, H. W., and J.P. Nichols. "Sources of Transuranium Solid Woste and Their Influence on the Proposed Notional Radiooctive Waste Repository." ORNL-TM3277. Jonvory 1971.

15. U.5. Nucleor Regulatory Commission. "A System for Clossifying Radioactive Waste Disposal-What Waste Goes Where?" NUREG-0456. June 1978.

16. Lowrence Livermore Laboratory. "A Review of Methods for the Detection of 10 $\mathrm{nCi} / \mathrm{g}$ of Transuranic Isotopes in Solid Waste." UCRL-52200. January 7, 1977.

17. Personal Communications with D. J. Kvam, Lowrence Livermore Laborotory. Memorandum of September 2I, 1978 (TRU Waste Inventory).

18. Sandia Laboratories. "TRU Waste Form and Packoge Criterio Meeting." SAND771178. August 1977.

19. Atomic Industrial Forum, Inc., National Environmental Studies Project 1976. "A Survey and Evaluation of Handling and Disposing of Solid Low-Level Nuclear Fuel Cycle Wastes." AF NESP-008. October 1976.

20. Colombo, P. and R.M. Neilson, Jr. "Critical Review of Properties of Solidified Radioactive Woste Packages Generated at Nuclear Power Reactors." BNLNUREG-50591. December 1976.

21. Science Applications, Inc. "Study of Transuranium Concentration Levels in Solid Radioactive Waste from Commercial Power Reactors," prepared for Electric Power Research Institute. EPRI NP-631. January 19:3.

22. Colombo, P. and R.M. Neilson, Jr. "Properties of Radioactive Wastes and Containers." BNL-NUREG-50774. January 1978.

23. U.S. Energy Research and Development Administration. "Final Environmental Impact Statement--Waste Management Operations, Idaho National Engineering Laborotory." ERDA-1536. September 1977.

24. U.S. Nuclear Regulatory Commission. "Environmental Survey of the Reprocessing and Waste Management Portions of the LWR Fuel Cycle--A Task Force Report." NUREG-01|6 (Sup. I to WASH-1248). October 1976.

25. Los Alamos Scientific Laborotory. "Transuranic Woste Research and Development Program." LA-5281-MS. January 1979.

26. Mulkin, R. "Characterization of Traisuranic Solid Wastes from a Plutonium Processing Facility." LA-5993-MS. Los Alamos Scientific Loboratory. June 1975.

27. McCurdy, D., et al, Los Alamos Scientific Laboratory. "Studies on Sorting and Characterization of Plutanium Process and Room-Generated Wastes." CONF$740406-12$.

28. Molecke, M. A. "Waste Isolation Pilot Plant Transuranic Wastes Experimentol Characterization Program: Executive Summary." SAND78-J356. Sandia Laborotories. Albuquerque, New Mexicc. November 1978. 
29. Hanford Engineering Development Loboratory. "Commercial Alpha Waste Program Quarterly Progress Report--April, May, June 1975," prepared for the U.5. Energy Research and Development Administration. HEOL-TME 75-102. Richland, Washington.

30. Blasewitz, A. G., C. R. Cooley, and G. L. Fichardson. "Quont ities and Character istics of Commercial Alpho Contaminated Solid Wastes in the U.S." HEDL-5A-705. Westinghouse Honford Company. Richland, Woshington.

31. Hanford Engineering Development Laboratory. "Nuclear Fuel Cycle and Production Programs Hrogress Report for July-December 1975," prepored for the U.S. Energy Research and Development Administration. HEDL-TME 76-22. Richland, Washington.

32. Zima, G. E. "A Brief Assessment of Some Technical and Rodiological Hazard Factors Affecting Clad Waste Monogement," prepared for the Energy Research and Development Administration. BNWL-2104. Battelle-Pacific Northwest Laboratories. July 30, 1976.

33. Holcomb, H. P. J. H. Horton, E. L, Wilhite. "Actinide-Soil interoctions in Waste Monogement of the Sovannah River Plont," DP-MS-75-118 (CONF 760214-1). Sovannah River Laboratory. Presented at the Actinide-Sediment Reoction Conference in Picnic.ad, Viashington, February 10-11, 1976.

34. Hanford Engineering Cevelopment Loboratory. "Commercial Alpho Waste Program Quarterly Progress Report--Wuctober-December 1974," prepared for the U.S. Energy Research and Development Administration. HEDL-ThiE 75-4l. Fichlond, Woshington.

35. Hespe, E.O. "Leoch Testing of Immobilized Rodivactive Waste Solids; A Proposol for a Standard Method." At. Energ, Review 9(1), 195 (1.971).

36. Hantord Engineering Development Laboratory. "Nuclear Fuel Cycle and Production Programs Progress Report for July-December 1975," prepured for the U.S. Energy Research and Development Administration. HEDL-Tirt 70-22. Fïchlond, Washington.

37. Colombo, P. ef al. "Froperties of Radiactive Wastes and Maste Containers." BNL-NUREG-50921, September 1978.

38. Turl, H. H., et al. "A Survey of Alpha Waste Generotion and Disposal as Solids in the U.S. Nuclear ruel Industry." BNWL-B-34. Batte!le hiemorial Institute. Richland, Washington. December 1970.

39. Los Alomos Scientific Laboratory. "Guarterly Repart - Transuranic Solid Waste Mianagement Research Programs April-June 1974." LA-5762-PF. October 1974. 
40. Sandia Laborator ies. "WIPP Conceptual Design Report." SAND77-0274. Albuquerque, New Mexico. June 1977.

41. U.S. Energy Research ond Development Administration. "Final Environmental Statement-Waste Monagement Operations, Hantord Reservation." ERDA-1538. Kichlond, Washington. Decemter 1975.

4?. Ohtsuka, K., ef al. "Developments in the Treatment of Solid Alpha-Bearing Wastes at the PNC Plutanium Fuel Facilities." Power Keactor and Nuclear Fuel Development Corporotion. Proceedings of the NEA/IAEA Technical Seminar: Treatment, Conditioning and Storage of Solid Alpha-Bearing Waste and Cladding Hulls, Par is, December 5-7, 1977.

43. Ziegler, D. L. and A. J. Johnson. "Fluidized Bed Incineration of Transuranic Contarninated Waste." Kockwell International. Proceeaings of the NEA/IAEA Technical Seminar, Paris, December 5-7, 1977.

44. Nickenzie, D. E., R. B. Poulson, and L. F. Crantham." "The Volume Reduction of Solid Alpho Beoring Woste by Molten Solt Combustion." Fockwell International. Proceedings of the NEA/IAEA Technicol Seminar, Par is, December 5-7, 1977.

45. Nallek, $H_{\text {. }}$ and M. Laser. "A Nev, Incinerator for Burning Radiooctive Waste." Proceedings of the NEA/IAEA Technical Seminar, Par is, Lecember 5-7, 1977.

46. Bond, W. H., J. W. Koenst, and D. F. Luthy. "The Treotment of Low-Leve! Waste af Maund Labarotory." Proceedings of the NEA/IAEA Technical Seminar, Poris. December 5-7, 1977. Mound Laboratory, Wonsanto Research Corporation. Miamisbury, Ohio.

47. Boersma, iv. D., H. E. Hootman, and P. H. Permar. "Developinent of an Integrated Facility for Processing TRU Solid Wostes at the Savonnoh River Plant." Proceedings of the NEA/IAEA Technical Serninor, Poris, December 5-7, 1977. Sovannah River Loboratory. Aiken, South Carolina.

48. Dillan, R. L. "Decontamination and ivelt Densification of Fuel Hull "Wostes." Praceedings of the NEA/IAEA Technical Seminar, Paris, December 5- $1,1977$. Battelle-Pocific Northwest Laboratories.

49. Schulz, W. W., A. L. Dressen, C. W. Hobbick. "Immobilization of Spent Cladding Hulls by Conversion to Silicate Forms-October 1974." ARH-SA-193 (CONF741086-1\%. Presented (in port) at the Winter National Meeting of the American Nuclear Society in Washington, D.C. October 27-November 1, 1974. Chemical Technology Laboratory.

50. Kupfer, N. J., et al. "Gloss Forms for Alpha Waste ivonogement," prepared for the U.S. Energy Kesearch and Development Administration. ARH-SA-239. Atlontic Richfield Hort ord Company. July 1975. 
51. Richardson, C. L. "Technologies for Recovery of Transuronics and Immobilizotion of Non-High-Level Wostes." Poper presented at International Symposium on the Monagement of Wastes from the LWF Fuel Cycle, Denver, Colorado, July 11-16, 1976. HEDL-SA 856. June 1976.

52. Kupfet, M. J., W. W. Schulz, C. W. Hobbick, J.E. Mendel. "Forms for Alpha Waste Management." Chernical Technology Loboratory, Atlontic Richfield Hanford Compony. Richlond, Washington.

53. Hanford Engineering Development Laborotory. "Division of Waste Management, Production and Repracessing Programs Progress Report for January-December 1976," prepared for the U.S. Energy Fieseorch and Development Administration. HELL-TNE 77-40. Richland, Washington.

54. Cooley, C. R., and D. E. Clark. "Treatment Technologies for Non-High-Level Wostes (USA)." Poper presented at International Symposium on the Mianagement of . Wastes from the LWR Fuel Cycle, Denver, Colorado, July 11-16, 1976. June 1976.

55. Cox, 11, D., et al., "Figure-of-Merit Analysis for a TRU Waste Processing Focility at INEL." Idoho National Engineering Loboratory. October 1978.

56. Levitz, N., et ol. "Volume Reduction and Salvaye Considerations for PlutoniumContaminated Ferrous Nietal." CONF-750902--9. Presented at 80th National Nieeting of the AlCht, Boston, Massachusetts, September 7-10, 1975. Argonne Ivational Loboratory. Argonne, lllinois.

57. U.S. Atomic Energy Commission. "Compaction of Radioactive Solid Waste." WASH 1167. A F port to the General Nianager's Task Force on AEC Operational Rodiooctive Waste Management. June 1970.

58. Andersan, K. J. "Atlontic Kichfield Hanford Company Compaction Facilities." ARH-SA-138 (CONF-721030--4), October 1972.

59. Herold, W. R. and D. F. Luthy, "Compaction of Alpho Contaminated Wastes," prepored for the U.S. Energy Research and Development Administration. MLN2282. Maund Laboratary, Monsanto Research Corporation. Miamisburg, Ohio. Jonuary $30,1976$.

60. Le:ch, R. $E_{1}$, and J. R. Divine, "woste Volume Reduction by Acid Digestion." HEDL-S.A-963. Poper presented at AIChE Meeting. Boston Massachusetts. September 7-10, 1975. Hanford Engineering Development Loboratory. Richland, Washington. June 1975.

61. Bourduin, L. C., et ol. "Controlled-Air Incinerotion of Transuranic-Contaminated Solid Woste." LA-UR-76-1515 (CONF-760S22--14\%. Presented of 14th ERDA Air Cleaning Conference, Sun Volley, Idaho, August 2-4, 1976. Los Alamos Scientific Laboratory. Los Alamos, New Mexico. 
62. Knights, L. M. "The Continuous Incinerotion of Plutonium-Bearing Scrop." ARHSA-39. Atlantic Richfield Hanford Company. Richland, Washington. September 15,1969 .

63. Lennemann, W. L, et ol. "Incineration of Fadicactive Solid Wastes." WASH-1/68. Notional Technical Informotion Service, U.S. Deportment of Commerce. August 1970.

64. Wiley, J. K. "lon Exchange Decontamination of Alkoline Solutions of Nuclear Woste." DP-ML-76-69. Poper presented at the National Meeting of the American Chemical Society, New Orleans, Louisiona, Niarch 20-25, 1977. Savonnoh River Lovoratory. Aiken, South Corolina.

65. Rockwell Internotional. "Disposul of Tronsuranic Solid Waste Using Afomics International's Molten Salt Combustion Process, II," prepared for the U.S. Energy Research and Development Administration. AL-EKDA-13169.

66. Ciork, W. E., and W. C. Ulrich. "Pressurized Aqueous Combustion of AlphoContarninated Woste, Final Program Stotus Report." URNL-TM-4366. Uak Ridge I vational Laboratory. Oak Ridge, Tennesset.

67. Los Alamos Scientific Laboratory. "Guarterly Report--Tronsuranic Woste Kesearch and Development Progrom Niorch-June 1973 and Annuol Report FY 1973 Transuranic Contaminated Solid Waste Treatment Progrom." LA-545!-PR,

68. Shefelbine, H. C. "Preliminary Evaluation of the Characteristics of Defense Tronsuranic Wostes." SAIND78-1850. Sandia Laboratories. November 1978.

69. wietzger, J. C., and A. M. Snyder. "Transport, Handling and Interim Storage of intermediate-Level Transuranic Waste at the INEL." TREE-1172. Idaho National Engineering Loborotory. September 1977.

70. Hanford Engineering Development Lahorotory. "Commercial Alpho Woste Program Quorterly Progress Report January-March, 1975." HEDL-TME 75-87. Richland, Washington.

71. Los Alomos Scientific Laborarory, "Quorterly Report--Transuranic Solid Waste Management Research Progroms October-December 1973." LA-5614-PR. Nay 1974.

72. Los Alomos Scientific Laboratory. "Quarterly Report--Transuranic Solid Waste Management Research Programs January-March 1974." LA-5666-PR. July 1974.

73. Los Alamos Scientific Laboratory. "Quorterly Report--Transuranic Solid Waste Mianogement Resecrch Programs July-September 1973." LA-55/2-PR.

74. Internationol Atomic Energy Agency. "Bituminization of Radiooctive Wastes." Technical Reports Series No. 116. Vienna. 1970. 
75. The National Research Council. "Solidification of High-Level Radioactive Wastes."

76. Kibbey, A. H., H. W. Godbee, and E. L. Compere. "A Review of Solid Radionctive Waste Proctices in Light-Water-Cooled Nuclear Reactor Power Plonts," prepared for the U.5. Nuclear Regulotory Commission. NUREG/CR-0144 ORNL/NUREG-43. Oak Ridge National Laboratory.

77. Y.S. Department of Energy. "Environmentol and Other Evaluotions of Alternatives for Long-Term Monogement of Stared INEL Transuranic Waste." DOE/ET-0081. February 1979.

78. U.S. Atomic Energy Commission. "Proceedings of the Rocky Flats Symposium on Safety in Plutonium Handling Facilities." CONF-710401

79. Emelity, L. A, and C. W. Christenson. "Processing of Plutonium-Contominoted Liquid Wastes at Los Alamos." Los Alamos Scientific Laboratory. Los Alamos,. New Mexico. April 15, 1971.

80. U.S. Atornic Energy Corrımission. "Transuranium Solid Waste Development Facility, Los Alomos Scientific Loboratory, New Mexico." ElS-NM-73-0795-F. Woshington, U.C. April 1973.

81. Battelle-Pocific Northwest Laboratories, "Chop-Leach Fuel Bundle Residues Densificotion by Melting," prepored for the Energy Research and Development Administration. BNWL-2132. November 1976.

82. U.S. Deportment of Energy. "Uraft Environmental Impoct Statement--W'aste Isolation Pilot Plant." Volume 2 of 2 Appendices. DOE/EI5-0026-D. April 1979.

83. "Nanogement of Rodioactive Wostes from Fuel Reprocessing," Proceedings. 5ymposium orgonized jointly by the OECD Nucleor Energy Agency and the International Atomic Energy Agency. Par is. 1972.

84. "Bituminizotion of Low and Mledium Level Radicactive Wastes," Proceedings. Seminar orgonized jointly by the UECD Nuclear Energy Agency and the Eurochemic Compony, Nioy 18-19, 1976.

85. U.5. Energy Research and Development Administration. "Final Environmental Impact Statement--Waste Nonagement Operations, Sovonnah River Plont." ERDA1537. Aiken, South Corolind. September 1977.

86. "Back End of the LWR Fuel Cycle." CONF-780304. Proceedings of the American Nucleor Society Topical Mieeting. Savannoh, Georgia. March 19-23, 1978.

87. Cooperstein, K., R. C. Erdmann, ond R. R. Fullwood. "Preliminary Environmental Analysis of a Generic Fuel Reprocessing Facility," prepared for the Environmental Protection Agency. EPA-520/3-75-003. Science Applications, Inc. Services. Moy 1974. 
88. Western, A. W., D. H. Hall, and John 5. Coogan. "Deepwell Disposol of Transuranic Contorninated Liquid Waste of the Nevodo Test Site." NVO-410-38 (CONF.761020. $-3) .1976$.

89. Albenesius, E. L. and W. C. Keinig. "Long Ronge Managernent of TransuroniurnConfominated Solid Wastes of Sovannah River." DP-MS-74-26 (COH.15 741026--i). Poper presented at Seminar on the Monagement of Plutonium-Contominoted Solid Wostes, Marcoule, France, Gctober 14-16, 1974. Sovonnah Kiver Laboratory. Aiken, South Corolino.

90. Duguid, J. O. "Final Keport on Assessment of DOE Low-Level Rodiouctive Solid Woste bisposal/Storoge Activities," prepared for U.5. Deporiment of Energy. BMI. 1984. Bottelle-Columbus Laborotories. Columbus, Ohia. Wovernber 30, 1977.

91. Monneschmidt, J. F, and E, J. Witkowski. "The Disposal of Rodionctive Liquid and Goseous Waste of Uak Ridge National Laborntory--December 1966," prepared for the U.S. Atornic linergy Commission, ORINL-TM-1832, Oak Ridge lvotionol Laboratory. Onk Ridge, Tennessee. August 1967.

92. Osioond, J. H., and D. L. Newcomb. "Radioactive Waste Disposal Lota for the: National Reactor Festing Station, ldaho." U.S. Atomic Energy Commission. HO. 120443-5upplement No. 3, Health Services Laboratary Report. Octaber 1906.

93. Osloond, 3. H. "Roglianctive Waste Disposal Data for the Wational Heoctor Testim, Station, idaho." U.S. Atomic Energy Commission. 100-12040-mupplement 1vo. 2, Health Services Laboratory Repart, November 1967.

94. Uslaond, J. H. and D. L. Newcomb. "Rodioactive Waste Disposal Doto fir 1"w National Reactor Testing Stotion, Idoho." U.S. Alomic Energy Cominission. I'xt. 12044-Supplement No, 4, Holth Services Loboratory Feport. April 1969.

55. U.5. Atomic Energy Commission. "Draft Environmental Statement - Mranagert it of Commercial High Level and Transuranium-Contominated Radioactive West: WASt-1539. September 1974.

46. U.5. Nuclear Regulatory Cormmission. "Proceedings of the Conference on His!" Level Rodiooctive Solid Waste Forms." INUREG/CP-0005. Uenver, Coloru. December 19m21, 1978.

97. Notionol Acodemy of Sciences. "Radiaactive Wostes at the Honford Reservotion A Technical Review." Nashington, D.C. 1978.

98. U.S. Energy Research and Development Administrotion. "Finol Environmentul Impact Statement-Waste Mandgement Operations, Idoho National Enginsiringt Loborotory." ERQA-1536. September 1977.

99. "Report to the Prestisent by the Interagency Review Group on Nuclear Wos" Manogement." THD-2\%,42. Washington, D.C. March 1979. 
100. U.S. Energy Research and Development Administration. "Droft Environmentol Statement--Manogement of Intermediate Level Fodioactive Waste," ERDA 1553D. Oak Ridge National Laborotory. Ook Ridge, Tennessee. Jonuary 1977.

101. Osloond, J. H., and B. L. Schmalz. "Radionctive Woste Disposol Doto for the Notonal Reocsor Testing Stotion, lacho." U.S. Atomic Energy Commission. IDO12040-Supplement No. I. Decernber 1966.

102. Levitz, N. Mi., B. J. Kullen, and M. J. Steindler. "Wranogement of Woste Cladding Hulls. Port 1. Pyrophoricity and Compoction." ANL-8139. Argonne Nationol Loborotory. Argonne, Illinois. February 1975.

103. U.S. Leporiment of Energy. "Draft Report of Task Force for Review of Nuclear Woste Management." DOE/ER-0004/D. February 1978.

104. Cord, U. H., and D. K. Wang. "Initial Drum Retrieval Interim Report, July 1974 to September 1976." U.S. Energy Fesearch and Levelopment Administration. TREE107\%. Idaho National Enginetring Laboratory. ivay 1977.

105. Cord, L. H. "Early Woste Retrieval Interim Report." U.S. Energy Research and Uevelopment Adrninistration. TREE-1047. Idaho Notional Engineering Loboratory. February 1977.

106. Kelley, J. A. "Incor poration of Savannah River Plant Radioxctive Waste into Glass." DP-N15-74-70 (COIVF-750535--1). Preselited of the Americon Ceromic Society iveeting, Washington D.C. Sovannah River Laborotory, Aiken, South Coroling. Nay 7, 1975.

107. Kvam, L. J. "Waste Wanagement Prcctices af Lawrence Radiotion Laborotory, Livermore, Californio ." UCRL-14320. September 28, 1965.

108. Corbit, C. D. "ineineration, Compaction, Segregation and Burial of Solid Fradioactive Wostes." DUN-6748. Louglas United Puclear, Inc. February 19, 1970.

10\%. Heold, W. R. "Atlantic Richfield Honford Company Transuranic Woste Retrievoble Burial." ART-SA-139 (CONF-721030-5). Atlontic Richtield Honiord Compony. Kichland, Washington. Octaber 1972.

110. Blomeke, J. O., and J. J. Perona. "Storage, Shipment, and Disposal of Spent Fuel Cladding." ORNL-TM-3650. Oak Ridge Notional Laboratory. Ook Ridge, Tennessee. January 1972.

11l. Brownell, L. E., et al. "The Thermalt Process for Immobilization of Radianctive Wastes." AKU.2059. Atlontic Richfield Hanford Company. Richlond, Woshinglon. April 15, 1971. 
112. Tarbell, J. M. "Thearetical Aspects of Solid Woste Incinerotion." SPST-75-452. Savannch Hiver Laboratory. Aiken, South Corolina.

113. Brownstein, M., and K. C. Levesque. "Experience with Cement Usage as the Binding Agent for Rodwaste." 79-1 I[-15. The Arnerican Sociely of Niechanicol Engineers, New York, 19\%.

114. Srrith, A. J. "Leoching of Radionctive Sludges Incorporateo in Cerrent and Bitumen." AEHE N.2223. Moy 1969.

115. Blone, D. E., and E. L. Murphy. "Wround Laboratory Activities on the Removal of Plutonium arid Uraniurn from Wastewoter Using Bone Char." MLNi-2371. Pround Laboratory, Monsanto Research Corporotion, Miomisburg, Uhio. September 30, 1976.

116. Stone, J. A., P. D. d'Lntrement. "iveosurernent and Control of Cement Set Tiries in Waste Solidification." UH-1404. Sovannah, River Laboratory, Aiken, South, Corolino.

117. Sinith, W. J. II, E. B. Fowler, and R. G. Stafford. "Experience in the Cleanup of Plutonium-Contaminated Land." LA-6731-MS. Los Alamos Scientific Laborotory. Los Alarnos, New Mexico. March 1977.

118. U.S. Department of Commerce. "Report to the President by the Interagency Heview (roup on Nuclear Waste Management. TID-28817 (Drof1). October 1978.

11\%. Kee, C. W. et al. "Upodated Projecions of Radionctive Wostes to be Generuted by the U.S. INuclear Power Industry." OH.JUL/TM-5427. Oak, Ridge National Laboratory. Uak Ridge, Tennessee. Decomber 1976.

120. Jansen, G., Jr., K. J. Scineider, and V. L. Harnmone. "A Conceptual System for Handling Alpho Bearing Wastes." BNWI-SA-500l. Presented of Seminar on the Nanagerient of Plutoniurn-Contaminated Solid Wostes, OECU IVuclear Energy Agency. Uctaber 14.16, 1974, Marcoule, Fronce, Battelle-Pocific Northwest Laborotories. Richland, Washington. Uctober, 1974.

121. U.S. Nuclear Fegulatary Commission. "Environmental Survey of the Reprocessing and Waste Manogement Portions of the LWK Fuel Cycle." NUREG-0116 (Supp. I to WASH-1248). October 1976.

122. North, E. D. "Solid Woste Generation in Reprocessing Nucleor Fuel." AlChE Symposium Series No. 154, Vol 72. 1976.

123. U.S. Atomic Energy Commission. "Tronsuranium Woste Disposal; Exemption and Continuing Regulatory Authority (10 CFR Port 150)." Federal Register 39 (178): 32922-32923. 1974.

124. Hebel, L. C., et al. "Report to the American Physical Society by the Study Group on Nuclear Fuel Cycles and Waste Management." Rev. Mod. Phy. 
125. U. S. Enesgy Research and Development Administrotion. "Draft Environmental Impoct Statement." ERDA=1545-D. Rocky Flats Plant Site. Vols I and 2. September 1977.

126. Ook Ridge Notional Laboratory. "A Brief Survey of Solid Radwaste Monogement it EROA Installations." ORNL/CF-76/129. Ook Ridge, Tennessee. April 30, 1976.

127. Seefeldt, W. B., W. J. Mecham, and M. J. Steindler. "Choracterization of Particulate Plutonium Releosed in Fuel Cycle Operations." ANL-75-78. Argonne National Loboratory. Argonne, Illinois. May 1976.

128. Dieckhone, J. E. "Sources, Production Rates ond Characteristics of ERDA l.owLevel Wastes." Managament of Low-Level Radionctive Waste, Volume I, pp. 103126. Pergamon Press. 1979.

129. U.S. Department of Energy. "Woste Information Management 5ystem, Fiscal Year 1978." Run Date 3/24/79.

I30 Battelle Northwest Laboratory. "Transuranium Rodionuclides--A Manual of Cood Practice." BNWL-5A-3075. January 1970.

131. Keeley, R. B. "Description of Solid Waste Expected from a Large Commercial Reprocessing Plont." Manogement of Low-Level Radiooctive Waste, Volume 1, pp. 89- 102. Pergomon Press. 1979.

132. Andarson, R. L., et ol. "Instifutional Rodioactive Waste." Volume 1, PB 279582 (NUREG/CR-0028). March i 978.

133. Duguid, J. 0. "Assessment of DOE Low-Level Radioactive Solid Waste Disposol/Storoge Activi:ies. Task 103, Final Report." BMI-1984. Prepared for U.S. Department of Energy, Battelle-Columbus Laboratories. Columbus, Ohio. November 30, 1977.

134. U.5. Environmental Protection Agency. "Environmental Analysis of the Uranium Fuel Cycle - Port 1..Fuel Supply." EPA-520/9-073-003-B. October 1973.

135. U.S. Environmental Protection Agency. "Environmental Anolysis of the Uranium Fuel Cycle - Part III-Nucleor Fuel Reprocessing." EPA-520/9-73-003-D. October 1973.

136. U.S. Environmental Protection Agency. "Environmental Analysis of the Uranium Fuel Cycle - Parf IV-Supplementory Anolysis," EPA-520/4-76-017. July 1976.

137. "Management of Wastes from the LWR Fuel Cycle." Proceedings of Internotional Symposium in Denver, Colorodo. CONF-76-0701. July 1i-16, 1976.

138. Emelity, L.A., C. W. Christenson, and W. H. Kline. "Operational Practices in the Treatment of Low- and Intermedjate-Level Radioactive Wostes: Argonne and Los Alamos Loboratories, United States of America." Practices in the Treatment of Low- and Intermediate-Level Radioactive Wastes. STI/PUB//I6. IAEA, Vienna. pp. 187-205. 1966 . 
139. Enders, J. W. "Solid Rodioacfive Waste Disposal at the Los Alamos Scientific Laboralory." Disposal of Radioactive Wastes into the Ground. STI/PUB/!56. IAEA, Vienna. pp. 17-35. 1967.

140. Christenson, C. W. "Treatment of a Highly Concentrated Woste Solution at Los Alamos Scientific Laboratory by Cement-Vermiculite." Treosment of Low- and Intermediate-Level Rodiogctive Woste Concentrates, STI/DOC/IO/82. TAEA, Vienno. Pp. 59-62. 1968.

141. Ryan, E. S., J. N. Vance, and N. E. Maos. "Aqueous Rodioactive Waste Treotment Plant at Rocky Flats." Practices in the Treatment of Low- and Intermediote-Level Radiooctive Wastes. STI/PUB/II6. |AEA, Vienna. pp. 517-526. 1966.

142. Ziegler, D. L. "Plutonium Waste Discards CY-67." CRDL-940561-102. Chemical Technology, Chemistry Fi and D, the Dow Chemical Company, Rocky Flats Divsion. Colaen, Colorado. July I8, 1968.

143. Mctiroy, J. L., W. F. Bonner, and J. E. Miendel. "Waste Solidification USA." BNWL-SA-5873. 1976.

144. U.S. Nuclear Regulutory Comrnission. "Final Generic Environmental Statement on the Use of Recyclad Plutonium in Mixed Oxide Fuel in Light Woler Cooled Reoctors." INUREG-0002. August 1976́.

145. U.5. Department of Energy Staff, Battelle-Pocific Northwest Laboratory Stoff, Selected Federal Government Groups. "Droft: Environmental Impocf Statemens, Management of Commercially Generated Fadioactive Woste." September 1977.

146. Ang, K. P. "Guantities of Actinides in Nuclear Reacior Fuel Cycles," LBL-\$682. Lawrence Berkeley Loboratory. Berkeley, Californio. April 9, 1975.

147. U.S. Atamic Energy Commission. "Radionctive Waste Nanagement." Part I, ACC Manual, Chapter 0511. Appendix 0511. (Now a LOE Manual Chapter) Approved 19 September 1973.

148. Wickland, C.E. "Pockaging Rocky Flots Waste." Nucleor Technology, vol. 32, January 1977.

14\%. FMC Corporation. "Selection of Waste Trcalment Process for Retrieved TRU Woste of Idaho National Engineering Loboratory." November 10, 1977.

150. U.5. Department of Energy. "Alternatives for Lang-Term Management of Defense Transuranic Waste at the Idoho National Engineering Loboratory." IDO-I0075, October 1978. 